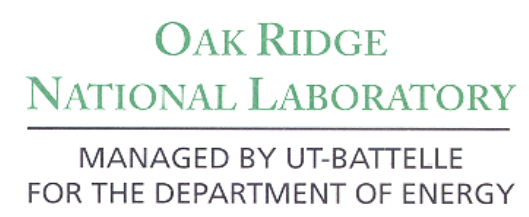

Emplacement Considerations for Criticality Safety in Low-LevelWaste Disposal
K. R. Elam

C. M. Hopper

C. V. Parks

(ORNL)

and

T. E. Harris

(U.S. NRC) 


\section{DOCUMENT AVAILABILITY}

Reports produced after January 1, 1996, are generally available free via the U.S. Department of Energy (DOE) Information Bridge.

\section{Web site http://www.osti.gov/bridge}

Reports produced before January 1, 1996, may be purchased by members of the public from the following source.

National Technical Information Service

5285 Port Royal Road

Springfield, VA 22161

Telephone 703-605-6000 (1-800-553-6847)

TDD 703-487-4639

Fax 703-605-6900

E-mail info@ntis.fedworld.gov

Web site

http://www.ntis.gov/support/ordernowabout.htm

Reports are available to DOE employees, DOE contractors, Energy Technology Data Exchange (ETDE) representatives, and International Nuclear Information System (INIS)

representatives from the following source.

Office of Scientific and Technical Information

P.O. Box 62

Oak Ridge, TN 37831

Telephone 865-576-8401

Fax $865-576-5728$

This report was prepared as an account of work sponsored by an agency of the United States government. Neither the United States government nor any agency thereof, nor any of their employees, makes any warranty, express or implied, or assumes any legal liability or responsibility for the accuracy, completeness, or usefulness of any information, apparatus, product, or process disclosed, or represents that its use would not infringe privately owned rights. Reference herein to any specific commercial product, process, or service by trade name, trademark, manufacturer, or otherwise, does not necessarily constitute or imply its endorsement, recommendation, or favoring by the United States government or any agency thereof. The views and opinions of authors expressed herein do not necessarily state or reflect those of the United States government or any agency thereof. 
Computational Physics and Engineering Division (10)

\title{
Emplacement Considerations for Criticality Safety in Low-Level-Waste Disposal
}

\author{
K. R. Elam, C. M. Hopper, C. V. Parks \\ Oak Ridge National Laboratory, \\ P.O. Box 2008, \\ Oak Ridge, TN 37831-6370 \\ and \\ T. E. Harris \\ U.S. Nuclear Regulatory Commission, \\ NMSS/DWM/DCB, \\ MS T7 F27, \\ Washington, DC 20555-0001
}

Date Published: June 2001

Prepared by the

OAK RIDGE NATIONAL LABORATORY

Oak Ridge, Tennessee 37831

UT-Battelle, LLC,

for the

U.S. DEPARTMENT OF ENERGY

under contract DE-AC05-00OR22725 



\section{CONTENTS}

Page

LIST OF TABLES $\ldots \ldots \ldots \ldots \ldots \ldots \ldots \ldots \ldots \ldots \ldots \ldots \ldots \ldots \ldots \ldots \ldots \ldots \ldots$

ACKNOWLEDGMENTS $\ldots \ldots \ldots \ldots \ldots \ldots \ldots \ldots \ldots \ldots \ldots \ldots \ldots \ldots \ldots$ vii

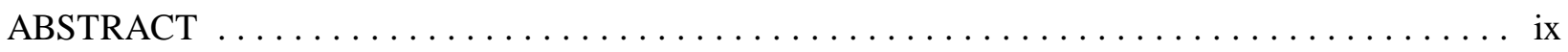

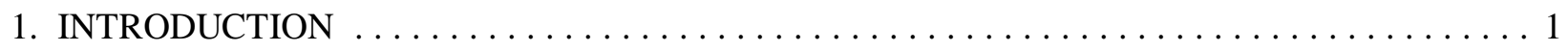

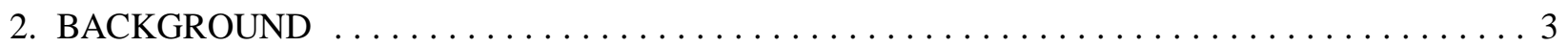

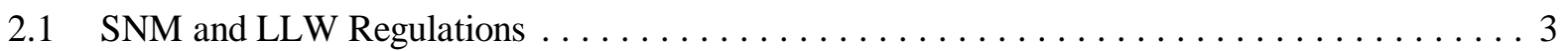

2.1.1 10 CFR Part 61, "Licensing Requirements for Land Disposal of Radioactive Waste" . 3

2.1.2 10 CFR Part 70, "Domestic Licensing of Special Nuclear Material" . . . . . . . . . . . 3

2.1.3 10 CFR Part 71, "Packaging and Transport of Radioactive Material" . . . . . . . . . 3

2.1.4 10 CFR Part 150, "Exemptions and Continued Regulatory Authority in Agreement

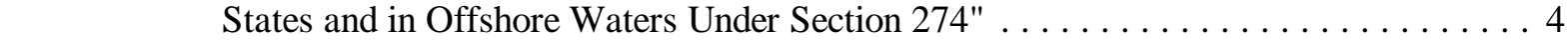

2.2 Current LLW Sites and Licensed Limits for SNM $\ldots \ldots \ldots \ldots \ldots \ldots \ldots \ldots \ldots \ldots$

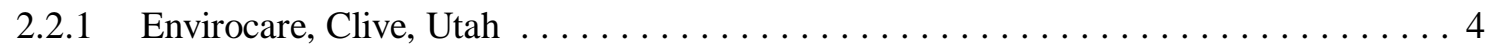

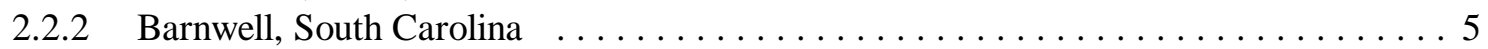

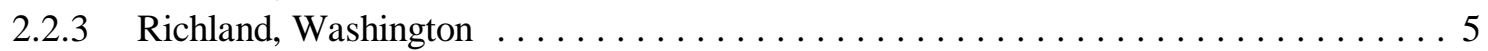

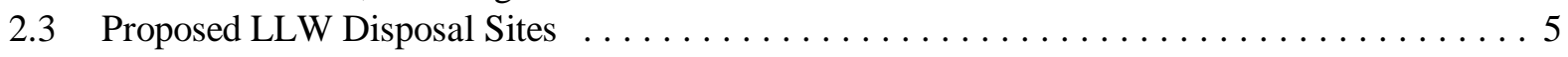

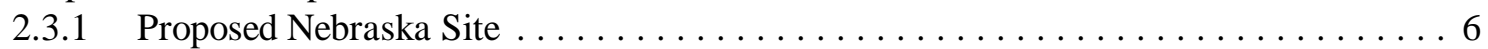

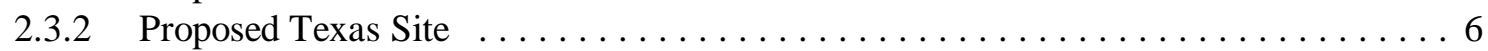

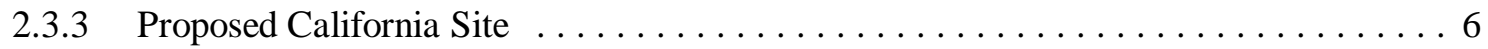

3. CRITICALITY SAFETY CONCERNS RELEVANT

TO LLW DISPOSAL FACILITIES $\ldots \ldots \ldots \ldots \ldots \ldots \ldots \ldots \ldots \ldots \ldots \ldots$

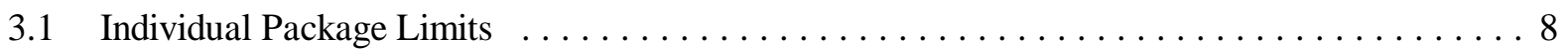

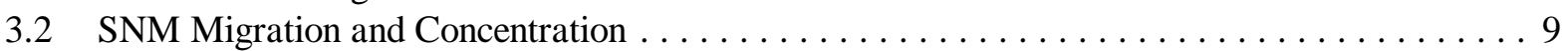

3.3 Coemplacement of SNM with Unusual Moderating Materials $\ldots \ldots \ldots \ldots \ldots \ldots \ldots \ldots$

4. SUMMARY OF PREVIOUS ANALYSES RELEVANT

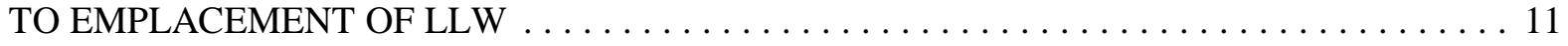

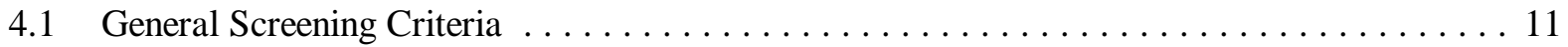

4.2 Transportation Exemptions and General-License Conditions $\ldots \ldots \ldots \ldots \ldots \ldots \ldots \ldots 12$

4.3 Criticality Potential for LLW Blended with Soil $\ldots \ldots \ldots \ldots \ldots \ldots \ldots \ldots \ldots \ldots \ldots \ldots$

4.4 Criticality Potential for Containerized LLW $\ldots \ldots \ldots \ldots \ldots \ldots \ldots \ldots \ldots \ldots \ldots \ldots$

5. CALCULATIONAL METHODS AND ASSUMPTIONS $\ldots \ldots \ldots \ldots \ldots \ldots \ldots \ldots \ldots \ldots$

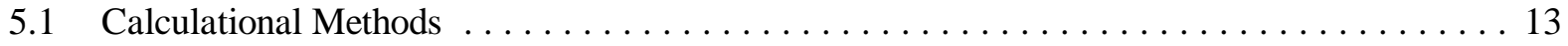

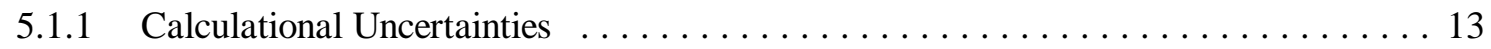

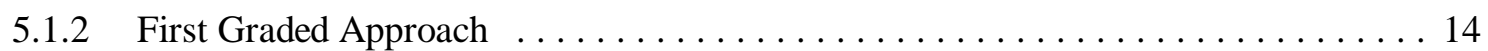

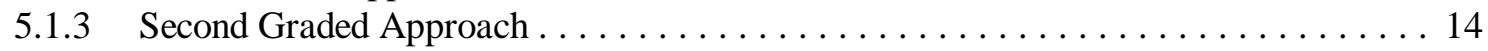




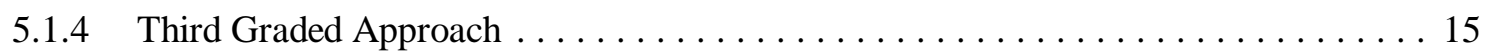

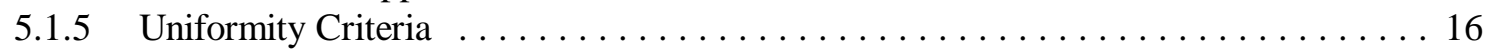

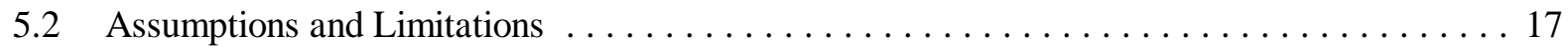

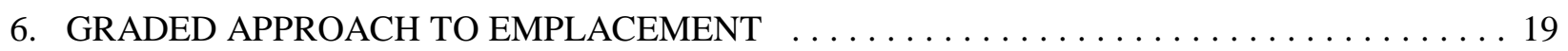

6.1 First Graded Approach - Areal Density and Enrichment Values . . . . . . . . . . . . . 19

6.2 Second Graded Approach - SNM Concentration at Limited Emplacement Depth _... . . . 20

6.3 Third Graded Approach - SNM Concentration at Limited Vault Depth . . . . . . . . . . . . 20

7. RECOMMENDATIONS AND OPERATIONAL VALUES $\ldots \ldots \ldots \ldots \ldots \ldots \ldots \ldots \ldots \ldots . \ldots \ldots$

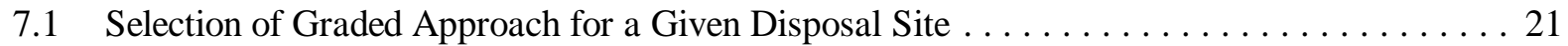

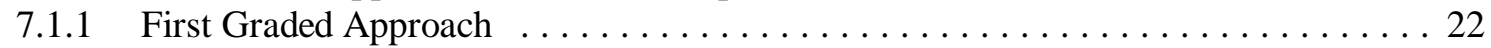

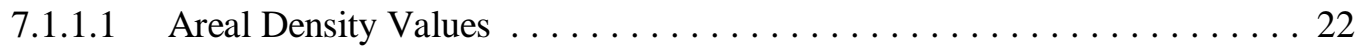

7.1.1.2 Subcritical Enrichment Levels for Different SNM Isotopes . . . . . . . . . . 23

7.1 .2 Second Graded Approach . . . . . . . . . . . . . . . . . . . . . . . . . . . . . 24

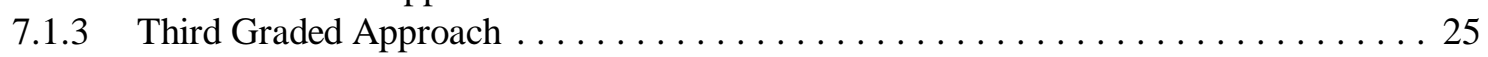

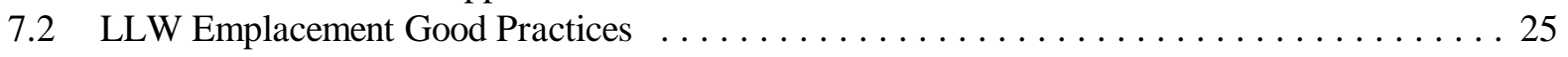

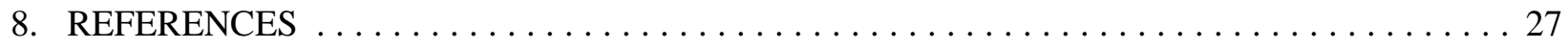

APPENDIX A - VERIFICATION OF KENO V.A CALCULATION
OF $\mathrm{SIO}_{2} /$ SNM SYSTEMS $\ldots \ldots \ldots \ldots \ldots \ldots \ldots \ldots \ldots \ldots \ldots \ldots \ldots \ldots \ldots \ldots \ldots \ldots \ldots \ldots \ldots$

APPENDIX B - DATA FOR FIRST GRADED-APPROACH METHOD $\ldots \ldots \ldots \ldots \ldots . \ldots 33$

APPENDIX C - EXAMPLE INPUT FILES $\ldots \ldots \ldots \ldots \ldots \ldots \ldots \ldots \ldots \ldots \ldots \ldots \ldots \ldots$

APPENDIX D - DATA FOR SECOND AND THIRD GRADED-APPROACH METHODS . . . . . 45

APPENDIX E - COMPARISONS OF OTHER ELEMENTS TO SILICON ........... 67

APPENDIX F - SPECIFIC ACTIVITY VALUES FOR SELECTED ISOTOPES $\ldots \ldots \ldots \ldots \ldots$ 


\section{LIST OF TABLES}

$\underline{\text { Table }}$

$\underline{\text { Page }}$

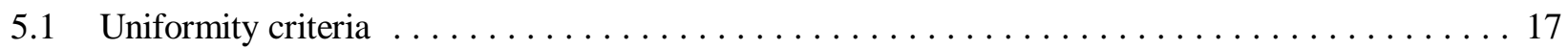

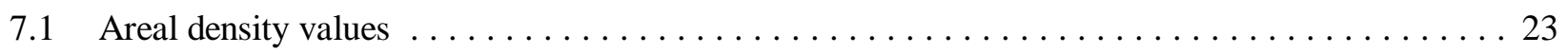

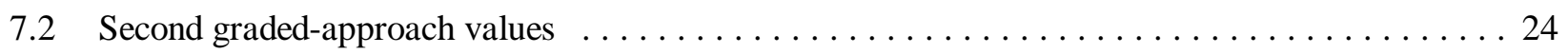

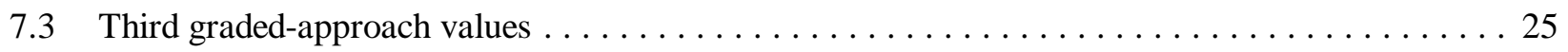

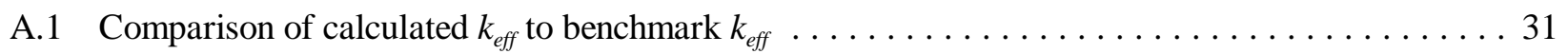

B.1 100 wt \% enriched uranium hydrogenous systems, $\mathrm{SiO}_{2}(\rho=1.9)$-reflected (Z-axis)

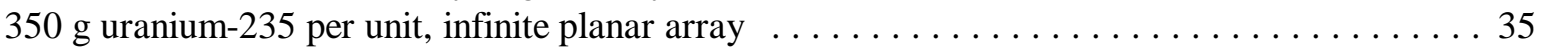

B.2 10 wt $\%$ enriched uranium systems, $\mathrm{SiO}_{2}(\rho=1.9)$-reflected (Z-axis)

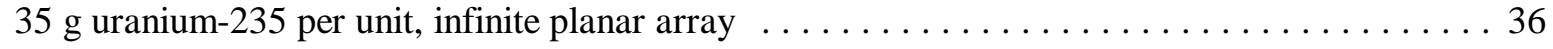

B.3 Uranium-233 hydrogenous systems, $\mathrm{SiO}_{2}(\rho=1.9)$-reflected (Z-axis)

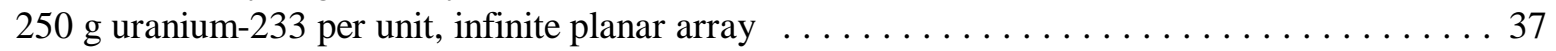

B.4 Plutonium-239 hydrogenous systems, $\mathrm{SiO}_{2}(\rho=1.9)$-reflected (Z-axis)

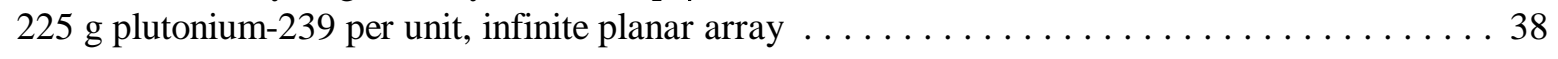

B.5 Plutonium isotopic mixture ${ }^{a}$ hydrogenous systems,

$\mathrm{SiO}_{2}(\rho=1.9)$-reflected (Z-axis), 225 g plutonium-239 per unit, infinite planar array $\ldots \ldots . .39$

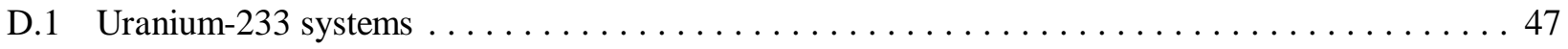

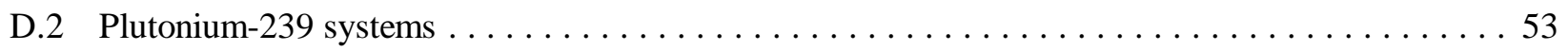

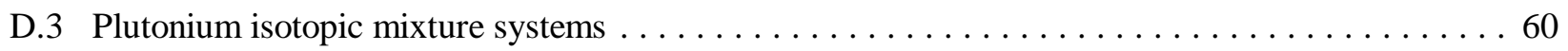

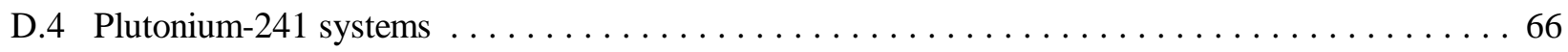

E.1 Substitution of element $\mathrm{X}$ into $\mathrm{SiO}_{2}$, forming $\mathrm{XO}_{2} \ldots \ldots \ldots \ldots \ldots \ldots \ldots \ldots \ldots \ldots$

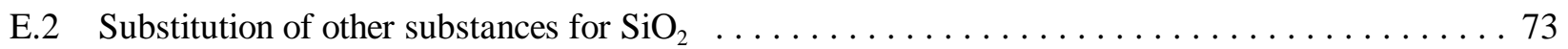

F.1 Specific activity values for selected isotopes $\ldots \ldots \ldots \ldots \ldots \ldots \ldots \ldots \ldots \ldots \ldots$ 


\section{ACKNOWLEDGMENTS}

This report is a summary of historic work supported by the Office of Nuclear Material Safety and Safeguards, U.S. Nuclear Regulatory Commission.

Careful reviews of the manuscript by R. M Westfall, M. E. Dunn, L. M. Petrie, and C. W. Forsberg are greatly appreciated. 


\begin{abstract}
The disposal of low-level radioactive waste (LLW) containing special nuclear material (SNM) presents some unusual challenges for LLW disposal site operators and regulators. Radiological concerns associated with the radioactive decay of the SNM are combined with concerns associated with the avoidance of a nuclear criticality both during handling and after disposal of the waste. Currently, there are three operating LLW disposal facilities: Envirocare, Barnwell, and Richland. All these facilities are located in U.S. Nuclear Regulatory Commission (NRC) Agreement States and are regulated by their respective state: Utah, South Carolina, and Washington. As such, the amount of SNM that can be possessed by each of these facilities is limited to the $10 \mathrm{CFR}$ Part 150 limits (i.e., $350 \mathrm{~g}$ of uranium-235, $200 \mathrm{~g}$ of uranium-233, and $200 \mathrm{~g}$ of $\mathrm{Pu}$, with the sum-of-fractions rule applying), unless an exemption is issued. NRC has applied these SNM possession limits to above-ground possession. The purpose of this report is to provide data which could demonstrate that SNM waste at emplacement will not cause a nuclear criticality accident.

Five different SNM isotopic compositions were studied: $100 \mathrm{wt} \%$ enriched uranium, $10 \mathrm{wt} \%$ enriched uranium, uranium-233, plutonium-239, and an isotopic mixture of plutonium (76 wt \% plutonium239, 12 wt $\%$ plutonium-240, and 12 wt \% plutonium-241). Three different graded-approach methods are presented. The first graded-approach method is the most conservative and may be applicable to facilities that dispose of very low areal densities of SNM, or dispose of material with a low average enrichment. It relies on the calculation of average areal density or on the average enrichment of SNM. The area over which averaging may be performed is also specified, but the emplacement depth is not constrained. The second graded-approach method relies on limiting the average concentration by weight of SNM in the waste, and on limiting the depth of the emplacement. This method may apply to facilities that emplace somewhat higher areal densities of SNM but do not use vaults or segmentation in the disposal emplacement. The third graded-approach method relies on limiting the average concentration by weight of SNM in the waste, and on the presence of segmenting barriers, such as vaults, which will mitigate interaction between units of SNM. This method may apply to facilities that use concrete vaults in their disposal areas, and allows even higher areal density of SNM in the disposal site.
\end{abstract}




\section{INTRODUCTION}

The disposal of low-level radioactive waste (LLW) containing special nuclear material (SNM) presents some unusual challenges for LLW disposal site operators and regulators. Radiological concerns associated with the radioactive decay of the SNM are combined with concerns associated with the avoidance of a nuclear criticality accident both during handling and after disposal of the waste. A criticality accident during emplacement of LLW in a disposal site could result in a radiation dose to people who are relatively close to the incident (i.e., workers). It would also very slightly increase the radioactive content of the disposal site, possibly resulting in an increase in dose to the public. Therefore, it is important that attention be paid to how SNM is disposed of in an LLW disposal facility.

Currently, there are three operating LLW disposal facilities: Envirocare, Barnwell, and Richland. All these facilities are located in U.S. Nuclear Regulatory Commission (NRC) Agreement States and are regulated by their respective state: Utah, South Carolina, and Washington. As such, the amount of SNM that can be possessed by each of these facilities is limited to the 10 CFR Part 150 limits (i.e., $350 \mathrm{~g}$ of uranium-235, $200 \mathrm{~g}$ of uranium-233, and $200 \mathrm{~g}$ of $\mathrm{Pu}$, with the sum-of-fractions rule ${ }^{a}$ applying), unless an exemption is issued. NRC has applied these SNM possession limits to above-ground possession.

The purpose of this report is to provide data which could demonstrate that SNM waste at emplacement will not cause a nuclear criticality accident. The report presents considerations for graded approaches to allow flexibility and is based on several assumptions. Users of the data should review the compatibility of these assumptions with the characteristics of the waste and disposal site. Alternatively, site-specific criticality safety analyses, based on other assumptions, could be performed to demonstrate that SNM waste at emplacement would not cause a criticality accident.

Previous studies provide the basis for much of the data presented in this report. One such study ${ }^{1}$ determined areal density limits for $100 \mathrm{wt} \%$-enriched uranium, $10 \mathrm{wt} \%$-enriched uranium, plutonium-239, and an isotopic mixture of plutonium (76 wt \% plutonium-239, 12 wt $\%$ plutonium-240, and 12 wt $\%$ plutonium-241) that would ensure subcriticality following emplacement of the waste. However, this study used very conservative models that may be overly restrictive. Two other studies ${ }^{2,3}$ looked at the result of long-term hydrogeological processes that might mobilize and subsequently increase the concentration of uranium-235 in disposal sites.

In this report, five different SNM isotopic compositions were studied: $100 \mathrm{wt} \%$-enriched uranium, $10 \mathrm{wt} \%$-enriched uranium, uranium-233, plutonium-239, and the isotopic mixture of plutonium described above. Plutonium-241 is also fissile, but it is very unlikely that pure plutonium-241 would be found in waste, since it is difficult to separate from other plutonium isotopes. Mixtures of plutonium-241 with other plutonium, usually including plutonium-240, are much less reactive. It is conservative to treat plutonium-241 as plutonium- 239 provided the plutonium- 240 concentration is at least equal to the plutonium- 241 concentration. ${ }^{4}$

Three different graded-approach methods are presented. The first graded-approach method is the most conservative and may be applicable to facilities that dispose of very low areal densities ${ }^{b}$ of SNM, or dispose

${ }^{a}$ The quantity of each SNM isotope present is divided by the graded approach value for that isotope. All of these ratios are then added together, and the sum must not exceed 1.0.

${ }^{b}$ Areal density is expressed in terms of mass of SNM per area at the base of the disposal unit. Limiting the areal density of SNM in an array of units is an established method of nuclear criticality control. 
of material with a low average enrichment. This approach relies on the calculation of average areal density or on the average enrichment of SNM. The area over which averaging may be performed is also specified, but the emplacement depth is not limited. The second graded-approach method relies on limiting the average concentration by weight of SNM in the waste, and on limiting the depth of the emplacement. This method may apply to facilities that emplace somewhat higher areal densities of SNM, but which do not use vaults or segmentation in the disposal emplacement. The third graded-approach method relies on limiting the average concentration by weight of SNM in the waste, and on the presence of segmenting barriers, such as vaults, that will mitigate interaction between units of SNM. This method may apply to facilities that use concrete vaults in their disposal areas, and it allows even higher areal density of SNM in the disposal site. 


\section{BACKGROUND}

\subsection{SNM and LLW Regulations}

This section summaries NRC regulations that are applicable to the disposal of SNM waste. In some cases, equivalent regulations in Agreement States may be slightly different and may vary from state to state. This section also provides a discussion of existing and proposed LLW disposal facilities.

\subsubsection{CFR Part 61, "Licensing Requirements for Land Disposal of Radioactive Waste"}

10 CFR Part 61 sets forth licensing requirements for land disposal of LLW. Subpart C provides requirements for performance objectives which a LLW facility shall meet to ensure the protection of the public, health, and environment. In addition to operational safety, long-term safety after closure of a facility is evaluated through the use of a performance assessment. This performance assessment estimates the dose to persons resulting from the transport of radionuclides from the disposal site, and limits are set in order to maintain this dose below certain levels. Limits on individual radionuclides based on performance assessment of a disposal site are required, and may be much lower than that required for criticality safety.

Part 61 defines three classes of waste (Class A, B, or C) that have different stability and intrusion protection requirements. This classification system (Part 61.55) is based on concentration values of several key nuclides. Classification of wastes containing only uranium isotopes is not covered specifically. Classification limits are provided for plutonium-241 and "alpha-emitting transuranic nuclides with half-life greater than 5 years," which does encompass the other plutonium isotopes.

In addition, Part 61.16(b) requires license applicants to describe procedures for avoiding nuclear criticality accidents, which address both storage of SNM prior to disposal and waste emplacement for disposal. It is envisioned that this report would provide a basis for demonstrating emplacement criticality safety. Compliance with this requirement could also be based on a site-specific analysis.

\subsubsection{CFR Part 70, "Domestic Licensing of Special Nuclear Material"}

10 CFR Part 70 sets forth licensing requirements for persons who receive, own, acquire, deliver, possess, use, and transfer SNM. Although Part 70 is primarily intended for fuel-cycle facilities (enrichment and fuel fabrication facilities), Part 70 does apply to LLW disposal facilities where the SNM above-ground possession quantities are greater than the 10 CFR Part 150 limits.

\subsubsection{CFR Part 71, "Packaging and Transport of Radioactive Material"}

10 CFR Part 71 sets forth requirements for packaging, preparation for shipment, and transportation of license material. In general, the type of package required to ship radioactive material is a function of the quantity (mass and activity) and the form (solid, liquid, or gas) of the material. For instance, strong tight containers (e.g., cardboard boxes) are acceptable to ship small quantities of medical isotopes, whereas heavy steel casks, which are tested to meet hypothetical accident conditions, are required to ship nuclear fuel. Part 71 provides several general licenses and exemptions for shipping SNM that depend on several factors, including the mass of SNM in the packages, the mass of SNM in the shipment, the concentration of SNM, and 
the presence of moderating materials. Part 71 also references applicable Department of Transportation (DOT) regulations.

\subsubsection{CFR Part 150, "Exemptions and Continued Regulatory Authority in Agreement States and in Offshore Waters Under Section 274"}

10 CFR Part 150 sets forth provisions where licensees in Agreement States are exempt from NRC licensing requirements and where licensees remain under the regulatory authority of the NRC. As it relates to SNM and LLW disposal, licensees in Agreement States are exempt from NRC regulations for possession of "special nuclear material in quantities not sufficient to form a critical mass." This term is defined in 150.11 as quantities not exceeding $350 \mathrm{~g}$ of uranium-235, $200 \mathrm{~g}$ of uranium-233, $200 \mathrm{~g}$ of plutonium, or combinations not exceeding the sum-of-fractions rule. However, disposal of SNM in an Agreement State may require an NRC license if the Commission determines that it should, based on "hazards or potential hazards thereof." Relative to LLW disposal facilities, NRC has applied the possession limits in Part 150 to aboveground possession prior to disposal. SNM that has been emplaced would no longer be subject to these possession limits.

\subsection{Current LLW Sites and Licensed Limits for SNM}

Currently, there are three LLW disposal facilities (Envirocare, Barnwell, and Richland). All these facilities are located in NRC Agreement States and are regulated by their respective state (Utah, South Carolina, and Washington). As such, the amount of SNM that can be possessed above ground by each of these facilities is limited to the 10 CFR Part 150 limits (i.e., $350 \mathrm{~g}$ of uranium-235, $200 \mathrm{~g}$ of uranium-233, and $200 \mathrm{~g}$ of plutonium, with the sum-of-fractions rule applying), unless an exemption is issued. NRC has applied these SNM possession limits to above-ground possession.

The disposal site designs currently in use vary widely from highly engineered systems with concrete vaults to landfill-style embankments. Emplacement depths range from around 20 to $45 \mathrm{ft}$. The gradedapproach values given in Sect. 7 are designed to provide data for this range of designs and emplacement depths. Even though current license limits for disposal of SNM vary somewhat, this variation is expected due to the differences in site design and emplacement methods. Also, each Agreement State has decided on its preferred methods for setting limits. In some cases, the license limits for SNM isotopes are based upon radiological concerns and are, therefore, much lower than that needed for criticality safety concerns.

\subsubsection{Envirocare, Clive, Utah}

Waste is received either uncontainerized (i.e., gondola rail cars) or containerized in drums, boxes, or intermodals. The containerized waste is typically removed from the container prior to disposal. Bulk waste materials and waste removed from the containers are placed in lifts with uncompacted thickness not exceeding 12 in. and are then compacted in a landfill-style above-ground embankment. Debris (nonsoil waste material, such as concrete) is coemplaced with waste or clean soil, but is restricted as to its volume fraction and placement. The embankment height is limited to $37 \mathrm{ft}$ of compacted waste with a 10.9-ft-thick multilayer cover.

Unlike other LLW disposal facilities, the Envirocare license sets a limit on the maximum average concentration for specific isotopes, including SNM isotopes, with a sum-of-fractions rule. 


\subsubsection{Barnwell, South Carolina}

Since 1996, the Barnwell facility disposes of waste containers in concrete overpacks or vaults within below-ground trenches. These vaults are approximately cubical with 10-ft outer dimensions (130 in. long, $108 \mathrm{in}$. wide, $128 \mathrm{in.} \mathrm{high)} \mathrm{and} \mathrm{are} \mathrm{stacked} \mathrm{three} \mathrm{vaults} \mathrm{high} \mathrm{in} \mathrm{the} \mathrm{trench.} \mathrm{These} \mathrm{new} \mathrm{trenches} \mathrm{are} \mathrm{typically}$ $1000 \mathrm{ft}$ long, $200 \mathrm{ft}$ wide, and $25 \mathrm{ft}$ deep. Before 1996, waste containers were placed directly into belowground earthen trenches. These older trenches are 15 to $22 \mathrm{ft}$ deep. Trenches are backfilled with sand prior to placement of a 6-ft cap. SNM waste must be received in containers that are at least 55 gals in volume (license condition 54).

From 1979 to 1997, the site was licensed by the NRC under 10 CFR Part 70. Under this license, the license allowed $4500 \mathrm{~g}$ of uranium-235 and $200 \mathrm{~g}$ of uranium-233 in undisposed waste. Plutonium was limited by concentration. This license also had disposal requirements. No single package could exceed $350 \mathrm{~g}$ of uranium-235, and had to have a minimum projected surface area of $2 \mathrm{ft}^{2}$. The average areal density could then not exceed $200 \mathrm{~g}$ uranium- $235 / \mathrm{ft}^{2}$, assuming a $95 \%$ confidence in the shipping values. If this $95 \%$ confidence was not met, the limit was decreased to $100 \mathrm{~g}$ uranium-235/ $\mathrm{ft}^{2}$. This areal density limit is not in the South Carolina license but has been retained in the facility operating procedures. The current license allows $350 \mathrm{~g}$ uranium-235, $200 \mathrm{~g}$ of uranium-233, or $200 \mathrm{~g}$ of plutonium in undisposed waste, with a sum-of-fractions rule applied to mixtures. In addition, transuranic isotopes are limited in license condition 40 to less than 1\% of the total activity of the waste. Typically, Barnwell receives only insignificant quantities of plutoniumcontaminated waste.

\subsubsection{Richland, Washington}

The Richland facility disposes of waste in below-ground trenches, similar to the Barnwell facility. Trenches are 20 to $45 \mathrm{ft}$ deep with a 5 -ft cap. Trenches may be no more than $150 \mathrm{ft}$ wide, $45 \mathrm{ft}$ deep, and $1000 \mathrm{ft}$ long. Waste is at least $8 \mathrm{ft}$ below grade. Waste is received and buried in "closed containers," unless specifically approved. No cardboard, corrugated paper, wood, or fiberboard containers are allowed. Metal containers are accepted.

Like the Barnwell facility, the Richland facility was licensed by the NRC under 10 CFR Part 70 prior to 1997. As such, the Richland license includes several criticality-related conditions. No package can have more than $100 \mathrm{~g}$ of uranium-235, $60 \mathrm{~g}$ of uranium-233, or $60 \mathrm{~g}$ of plutonium, with the sum-of-fractions rule applied for mixtures. Also, no package can have more than $15 \mathrm{~g}$ per cubic $\mathrm{ft}$ of the above three materials, and the SNM is supposed to be "essentially uniformly distributed" in the package (license condition 27). During disposal, there are requirements for package placement for SNM. An "accumulation" of packages is defined as a group containing no more than $350 \mathrm{~g}$ uranium-235, $200 \mathrm{~g}$ of uranium-233, or $200 \mathrm{~g}$ of plutonium (with sum-of-fractions rule for mixtures). Each accumulation of packages is disposed with a minimum of 8 in. of soil or $4 \mathrm{ft}$ of non-SNM-bearing waste in all directions from other SNM waste accumulations (license condition 52).

\subsection{Proposed LLW Disposal Sites}

Several LLW disposal facilities have been proposed for construction. However, in the late 1990's state regulators and governments in Nebraska, Texas, and California decided not to pursue licensing for various reasons. Even though these facilities may not be constructed, it is believed that the design of future LLW facilities would be similar to these proposed facilities. Therefore, the method of disposal is discussed for each of these facilities. 


\subsubsection{Proposed Nebraska Site}

The Nebraska site proposed disposal of waste containers in above-grade concrete vaults that are backfilled with grout before capping. The vault roof is 3 -ft-thick concrete. A multilayer cover, consisting of a waterproof membrane, sand, clay, more concrete, and soil, totaling a thickness of $17 \mathrm{ft}$, was proposed. The vaults were to be constructed of low-permeability concrete with close-spaced reinforcing steel. Waste in drums would be placed 4 to a pallet, and stacked no more than 4 pallets high. Boxes were proposed to be stacked 3 to 4 high within a vault. Vault heights were estimated to be in the range of $28 \mathrm{ft}$.

\subsubsection{Proposed Texas Site}

The Texas site proposed disposal of waste containers in cylindrical concrete vaults that are preplaced into below-ground trenches. The vaults were proposed to be $9 \mathrm{ft}$ in height and $8 \mathrm{ft} 4 \mathrm{in}$. in diameter, with 10-in.-thick walls and 13.5-in.-thick tops and bottoms. The vaults were to be placed a minimum of $18 \mathrm{in}$. apart in a triangular-pitched array, and stacked two deep. Canisters would have been filled with waste packages and then backfilled with grout. The space between the canisters was to be filled with sand. The trench depth was in the range of $33 \mathrm{ft}$.

\subsubsection{Proposed California Site}

The California site proposes disposal of waste containers directly into earthen trenches. This method of disposal is similar to that formerly used by the Barnwell site and currently employed by the Richland site. Unique to the California design, the drums will be placed on their sides. A trench depth of $60 \mathrm{ft}$ is proposed, with $40 \mathrm{ft}$ for the waste and a $20-\mathrm{ft}$ soil cap. 


\section{CRITICALITY SAFETY CONCERNS RELEVANT TO LLW DISPOSAL FACILITIES}

Criticality safety is an important consideration in the disposal of LLW containing SNM. A nuclear criticality accident during emplacement of LLW in a disposal site could result in a radiation dose to people who are relatively close to the incident (i.e., workers). It would also very slightly increase the radioactive content of the disposal site, possibly resulting in an increase in doses to the public. Therefore, it is important that attention be paid to how SNM is disposed of in a LLW disposal facility.

Spontaneous nuclear fission occurs naturally in a very small percentage of radioactive decays of SNM atoms. When fission occurs, neutrons are emitted along with the nuclear fragments (e.g., cesium and strontium atoms). These neutrons may be absorbed by a non-SNM nucleus, may be absorbed by a SNM nucleus and cause fission, or may be lost from the system through leakage or some other mechanism. In natural uranium (enrichment of $0.71 \mathrm{wt} \%$ uranium-235) that is present in most soil, the neutrons produced during spontaneous fission are typically absorbed by a non-SNM nucleus.

Unlike spontaneous nuclear fission, criticality is a chain reaction of fission events where large numbers of neutrons are produced. Criticality occurs when, on average, one neutron produced during a fission goes on to produce one other fission. Since more than one neutron may be produced during each fission event, some neutrons can be lost to absorption or leakage while still possibly leaving enough neutrons to produce additional fissions. In other words, criticality requires a balance between neutron production and neutron loss. Criticality safety relies on minimizing neutron production and maximizing neutron losses.

The probability of a particular reaction between a neutron and a nucleus, for example absorption that causes fission, is given the term "cross section," and is a property of the particular isotope and the energy of the neutron. In other words, if a given material is exposed to neutrons, the rate at which any particular nuclear reaction occurs depends upon the number of neutrons, their energy, and the number of nuclei of the particular material. In general, SNM isotopes tend to be more likely to undergo fission when interacting with relatively low-energy neutrons. Therefore, their cross section for fission is higher for slow neutrons than for fast neutrons.

Even though a criticality can intentionally be produced with a relatively small mass of SNM under ideal conditions, it is more difficult for a criticality to occur in more diffuse material (e.g., LLW). However, it is not inconceivable for a criticality accident to occur at an LLW disposal facility. For example, if containers with SNM of sufficient density, which are not critical individually, were stacked in a large array (e.g., in a disposal cell) a criticality could occur. Specific considerations that affect criticality safety are discussed in the following sections. In general, the most important factors that affect the criticality safety of an LLW disposal site are the following:

1. the quantity, isotope, enrichment, and distribution of the SNM;

2. the presence of moderating materials, and their distribution; and

3. the presence of neutron-absorbing materials, and their distribution.

The quantity of SNM present in a disposal site can be described using different measures. One common measure is concentration in terms of grams of SNM per cubic foot. Even though this value is generally easy to determine in a waste package, it is heavily dependent on void space. If the package is compacted, or the contents emptied, this concentration could change dramatically. Another way to measure SNM is areal density, which is the mass of SNM per unit area of a disposal site as if it were projected

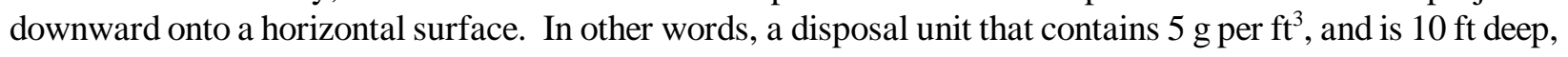


would have an areal density of $50 \mathrm{~g}$ per $\mathrm{ft}^{2}$. The advantage of using areal density as a measure of the SNM in a disposal site is that vertical settling or compaction will not change the areal density value. This measure is used to describe the values in the first graded-approach method. The second and third graded-approach methods use concentration values in terms of grams of SNM per gram of waste.

The isotopic composition and enrichment of the SNM depends on the waste stream. To be used as fuel in reactors, natural uranium is enriched in uranium-235. Enrichment is a ratio of the weight of uranium-235 to total uranium, and is typically expressed as a percent. Most nuclear fuel is enriched to $<5 \mathrm{wt} \%$; therefore, waste streams from fuel fabrication facilities contain low-enriched uranium. However, nuclear fuel for naval submarines is enriched to $>90 \mathrm{wt} \%$. The criticality concern increases with enrichment. To bound these two types of waste streams, this report provides data for $10 \mathrm{wt} \%$ - and $100 \mathrm{wt} \%$-enriched uranium. Significant quantities of plutonium and uranium-233 are not common in commercial or industrial waste streams. These waste materials are predominately generated by Department of Energy (DOE) facilities.

The distribution of SNM in the disposal site is also an issue. Regions of higher SNM concentration could pose a criticality concern, even if the average concentration is quite low. Because of this concern, Sect. 6 of this report gives values for the mass of waste or the area over which the SNM distribution may be averaged.

When SNM is in solution, or present as finely divided particles, such as in LLW, the presence of a "neutron moderator," such as water or hydrocarbons (e.g., plastics), can significantly reduce the amount of SNM required for criticality ${ }^{6}$ Slow neutrons have a far greater probability of causing fission in uranium-235 or plutonium-239. However, most neutrons produced by a fission are "fast" neutrons. A moderator slows neutrons as the neutrons collide with the moderator atoms. Elements with light nuclei (e.g., hydrogen, deuterium, and carbon) are particularly effective neutron moderators. An optimum degree of moderation exists because if the ratio of hydrogen to uranium becomes too large, the probability that the hydrogen will absorb the neutron becomes larger. Materials that capture neutrons are termed absorbers, and most materials are both moderators and absorbers to varying degrees. The effect of moderators with very low neutron-absorption characteristics (e.g., beryllium) is discussed in Sect. 3.3 (also see ref. 7).

Many materials found in LLW or in the soil surrounding the emplaced waste are very effective neutron absorbers. Section 5.2 discusses the calculational method used to derive the values in Sect. 6, and why silicon dioxide was chosen as a surrogate material for waste. Because most other elements found in soil or waste are better neutron absorbers than silicon, this calculational method produced conservative results. However, these other elements (e.g., calcium, iron, copper) are likely to be present in waste and soil, and their neutronabsorbing properties reduce the likelihood of an inadvertent nuclear criticality. Some materials, cadmium and boron in particular, are extremely effective neutron absorbers. Such neutron absorbers may be used to provide criticality control in waste packages. However, in a disposal site environment, it is difficult to predict if the neutron absorber will stay with the SNM, and not leach away over time. Therefore, it is not recommended that neutron absorbers in soil be relied upon for long-term criticality control in an LLW disposal site.

\subsection{Individual Package Limits}

The requirements of 10 CFR Part 71 ensure criticality safety for transport of packages containing SNM. For disposal facilities licensed by NRC Agreement States, the amount of SNM in packages is further constrained by the mass limits in 10 CFR Part 150. Part 150 defines the amount of SNM which can be licensed by an Agreement State as $350 \mathrm{~g}$ of uranium-235, $200 \mathrm{~g}$ of uranium-233, and $200 \mathrm{~g}$ of plutonium. If mixtures of SNM isotopes are present in the waste, the sum-of-fractions rule applies. These package limit quantities of SNM have been shown to be subcritical. 


\subsection{SNM Migration and Concentration}

One assumption that could be made regarding emplacement criticality is that the SNM does not move from its original "as disposed" position. Following disposal, however, it is reasonable to assume that the container (i.e., metal drum) will degrade in tens of years. Therefore, another assumption that could be made is that the containers are no longer able to physically contain the waste. When the containers fail, the waste could either settle and fill the bottom of a concrete vault or settle within the trench. In these situations, the waste could become slightly denser, but the areal density, or grams of SNM per square $\mathrm{ft}$, and the concentration of the SNM within the waste would be essentially unchanged. This report considers that this type of physical movement could occur.

Another situation would be that water could infiltrate the disposal unit and that the SNM, particularly uranium, may change chemically and may move from its original disposal position. In this case, the concentration of the SNM in the waste would change. One could further assume that the SNM in solution with the infiltration water could move horizontally, vertically, or both, and be redeposited in another location. This process is called "reconcentration." Physical barriers to movement (e.g., vaults) can reduce the amount of SNM that is available for migration and reconcentration. However, such barriers can also act as collection points for mobile SNM. The larger the volume over which SNM collection is considered, the larger the potential increase in the local concentration of SNM. If this situation occurs, the distribution of SNM over the entire disposal site would need to be considered to evaluate the concern that large masses of SNM could be reconcentrated, thereby posing the potential for a nuclear criticality accident.

To evaluate this reconcentration concern, two previous studies, 2,3 regarding uranium have been performed. The scope and results of these studies are discussed in Sects. 4.3 and 4.4. They assumed that the dominant uranium mineral was uraninite, or uranium dioxide $\left(\mathrm{UO}_{2}\right)$. Uranium dioxide is a common uranium compound that is relatively insoluble in water. Other compounds of uranium are highly soluble. These compounds include uranyl fluoride, uranyl nitrate, and uranyl potassium carbonate. Soluble compounds of plutonium include plutonium fluoride and plutonium chloride. If soluble SNM compounds were present in LLW, the disposal facility operator may not be able to determine their presence from available documents. NRC Forms 541, "Uniform Low-Level Radioactive Waste Manifest," and 741, "Nuclear Material Transaction Report," require that only prevalent chemical forms of the waste be reported. This information may or may not include the SNM chemical form. Therefore, some uncertainty exists on the presence of soluble SNM.

Even though these compounds were not considered in the above-referenced studies, two processes need to happen for reconcentration of SNM to occur: The first process is that the SNM needs to be mobilized in water. Highly soluble forms of SNM would be mobilized much faster than oxides. The second process is that the SNM would then need to be immobilized. (If the SNM is not immobilized, its concentration does not increase and there is no increased likelihood of a criticality accident.) Therefore, the conclusions of the studies relative to the processes and rates of immobilization would not be affected if the SNM was highly soluble. Moreover, if the void space between containers is filled with soil material containing silica (sand), it is likely that the SNM would not migrate. The good practice segment in Sect. 7 recommends backfilling the void space between SNM containers with sand or grout and minimizing the quantity of soluble SNM to the extent practicable.

In addition, substantial quantities of soluble SNM compounds are not anticipated to be present in LLW. Because SNM is expensive to make and soluble SNM is easily recoverable, it is likely that generators would reprocess this type of waste and recover the majority of the soluble SNM material. 


\subsection{Coemplacement of SNM with Unusual Moderating Materials}

Because water is both a good moderator (a material that slows neutrons) and a poor absorber (a material that does not capture neutrons), it is common in criticality safety evaluations to assume that water may be present with the SNM. The data presented in this report makes this assumption. However, there are other materials (e.g., beryllium, graphite, and heavy water $\left(\mathrm{D}_{2} \mathrm{O}\right)$ ) that are less efficient neutron moderators than water, but have lower neutron-absorption characteristics than water. Therefore, a system of SNM with such moderators can become critical at a lower concentration than it would with only water present. 7 These moderating materials are used at many nuclear facilities, and may be present with the SNM in the LLW. Note that the data presented in this document are not applicable if the LLW contains more than trace amounts $(0.1 \mathrm{wt} \%)$ of these materials. Furthermore, it is a good practice to segregate SNM LLW from LLW containing beryllium, graphite, or heavy water. 


\section{SUMMARY OF PREVIOUS ANALYSES RELEVANT TO EMPLACEMENT OF LLW}

\subsection{General Screening Criteria}

NUREG/CR-6284, 1, which was prepared to provide screening criteria for NRC licensing of LLW facilities, presents very conservative areal density limits. In a license application, if a licensee proposed values below these limits, then NRC would not need to perform any additional criticality review to ensure safety. Operational limits were determined from surface-density spacing criteria that were developed in the $1960 s^{8}$ and $1970 \mathrm{~s}^{9}$ and applied by the NRC. ${ }^{10}$ The surface-density spacing criteria developed in this report are based upon SCALE ${ }^{11}$ calculations for establishing operational limits by taking into consideration the following:

1. type and isotopic compositions of SNM (100 wt \%-enriched uranium, $10 \mathrm{wt} \%$-enriched uranium, plutonium-239, and an isotopic mixture of plutonium containing $76 \mathrm{wt} \%$ plutonium-239, $12 \mathrm{wt} \%$ plutonium-240, and 12 wt \% plutonium-241);

2. single-package mass limits based upon the fraction critical (i.e., ratio of the mass of a single unit to the bare critical mass of the same SNM in a similar shape);

3. optimization of SNM density or degree of moderation;

4. optimization of cylindrical geometry height-to-diameter ratios;

5. use of realistic maximum reflector materials (i.e., silicon dioxide as opposed to unquantifiable damp soil or water);

6. reflector spacing;

7. interspersed moderation and container materials;

8. array lattice patterns; and

9. calculational uncertainties.

The surface-density spacing criteria that evolved from these optimization and maximization studies provided conservative license review screening criteria for which no other assumptions must be made except that significant horizontal migration of SNM will not occur. As augmented with limiting enrichment values to ensure subcriticality, other SCALE computations, 7 and SCALE computations for uranium-233 performed for this report, NUREG/CR-6284 provides the bases for the first graded-approach method that can be applied uniformly to all license applications. 


\subsection{Transportation Exemptions and General-License Conditions}

NUREG/CR-5342 was prepared to support possible changes to 10 CFR Part 71. The report reviews the current transportation regulations, assesses their technical bases, and provides recommendations on changes to Part 71 relative to fissile material exemptions and general licenses. Among other information, minimum subcritical masses and limiting concentrations of the three primary SNM isotopes (uranium-235, uranium-233, and plutonium-239) in various moderators of interest (water, polyethylene, silicon dioxide, carbon, beryllium, and heavy water) were provided. The SCALE computational results in NUREG/CR-5342 $2^{7}$ augment information in NUREG/CR-6284 to provide the basis for the first graded approach.

\subsection{Criticality Potential for LLW Blended with Soil}

NUREG/CR-6505, Vol. 12 was prepared to aid the NRC in evaluating the possibility that SNM in waste might reconcentrate after disposal. It was developed specifically to examine the potential for uranium migration and deposition into a potential critical configuration within an LLW disposal facility like Envirocare, where the waste is not generally disposed within containers. The report considered the initial uniform distribution and temporal/environmental redistribution of $100 \mathrm{wt} \%$-enriched uranium into infinite slabs, infinite cylinders and spheres having variable uranium-235 densities and variable degrees of water moderation in a surrogate waste matrix $\left(1.6 \mathrm{~g} \mathrm{SiO}_{2} / \mathrm{cm}^{3}\right)$, reflected by $\mathrm{SiO}_{2}$. Critical areal densities and mass values were derived. NUREG/CR-6505, Vol.1, taken together with ref. 3 and augmented with SCALE calculations for uranium-233, plutonium-239, and the isotopic mixture of plutonium, provides the basis for the second graded approach.

\subsection{Criticality Potential for Containerized LLW}

NUREG/CR-6505, Vol. 2 ${ }^{3}$ with containerized waste, was prepared as a companion study to ref. 2 and explored the reconcentration process at humid sites with containerized waste. It was developed specifically to examine potential migration of $10 \mathrm{wt} \%$-enriched uranium and deposition into a potential critical configuration in a LLW disposal facility like Barnwell, South Carolina, where the waste is disposed of in containers and within vaults. Critical areal densities and mass values were derived. The report considered the initial uniform distribution and temporal/environmental redistribution of $10 \mathrm{wt} \%$-enriched uraniuminto infinite slabs, infinite cylinders and spheres having variable uranium-235 densities and variable degrees of water moderation in a surrogate waste matrix (i.e., $1.6 \mathrm{~g} \mathrm{SiO}_{2} / \mathrm{cm}^{3}$ ) reflected by $\mathrm{SiO}_{2}$. NUREG/CR-6505, Vol. 2, taken together with ref. 2 and augmented with SCALE calculations for uranium-233, plutonium-239, and the isotopic mixture of plutonium, provides the basis for the second graded-approach method. 


\section{CALCULATIONAL METHODS AND ASSUMPTIONS}

\subsection{Calculational Methods}

Criticality calculations used in developing the subcritical values in this report were performed using the SCALE computer code system, Version 4.4, which includes XSDRNPM and KENO V.a. ${ }^{12}$ To improve efficiency, many of the preliminary calculations were performed with the 27-group ENDF/B-IV neutron crosssection library. Calculations used to define values in this document were performed with the more recently evaluated 238-group ENDF/B-V neutron cross-section library. ${ }^{c}$

As discussed in Sect. 4, much of the data were derived from previously published studies ${ }^{1-3,7}$ The data were augmented by using methods outlined in these studies, and calculating data for SNM isotopes that were not previously evaluated (e.g., uranium-233). This accounts for much of the variation seen in the calculational methods used for the different graded approaches.

The physical dimensions of the specified values (areal density in $\mathrm{g} / \mathrm{ft}^{2}$, and other dimensions of height in $\mathrm{ft}$ ) were chosen to be compatible with information available to LLW disposal facility personnel. The gram was selected because grams are the units provided on NRC Form 541 for the SNM content in a container. Square feet was selected because most personnel working at an LLW disposal facility are familiar with their building, trench, bunker, etc., dimensions in terms of square feet. If needed, the conversion of $\mathrm{g} / \mathrm{ft}^{2}$ to $\mathrm{kg} / \mathrm{m}^{2}$ may be accomplished by multiplying by the constant 0.010763 . Other dimensions of height are given in $\mathrm{ft}$ to be compatible with engineering drawings and other LLW disposal facility records. The conversion of ft to $\mathrm{m}$ may be accomplished by multiplying by the constant 0.3048 .

The basis for comparison between criticality calculations for different cases was the neutron multiplication factor $k$, which is a measure of the potential of the modeled system to support a self-sustaining fission chain reaction. ${ }^{5}$ In an infinite system with no neutron leakage, $k_{i n f}$ is defined as the ratio of the rate of neutron production to the rate of neutron absorption. In a finite system, $k_{\text {eff }}$ is defined as the ratio of the rate of neutron production to the sum of the rates of neutron absorption and leakage. In a critical system, $k$ is equal to 1 . However, to account for some of the uncertainties in the calculational methods and cross sections, a calculated $k<1$ may be used as a "critical" value.

\subsubsection{Calculational Uncertainties}

While the SCALE computer code system and the neutron cross-section libraries that were used have been extensively validated against many critical benchmark experiments, $\frac{13}{13}$ there are not many documented critical experiments utilizing SNM and $\mathrm{SiO}_{2}$ systems. Recently published critical experiments performed at the Institute of Physics and Power Engineering within the Russian Federation allow for verification that the SCALE computer code system and libraries do a reasonably good job of calculating enriched uranium and $\mathrm{SiO}_{2}$ models with variable levels of moderation (see Appendix A). Those calculations confirm that the computational biases for variably moderated "soil like" systems that are contaminated with uranium are relatively small. Therefore, the subcritical and operational margins used for the graded-approach values are

${ }^{c}$ The computations were executed on workstations CA37 and CA38 at the Oak Ridge National Laboratory, Computational Physics and Engineering Division, Nuclear Engineering Applications Section. The modules and cross-section data set creation dates were the following: BONAMI-1/12/99; NITAWL-9/18/98; XSDRNPM-5/6/99; KENO V.a-7/31/98; and scale.rev07.xn238-6/22/98. 
judged to safely bound "soil-like" systems that are comprised of enriched uranium, silicon dioxide, hydrocarbon and/or water moderators, and all other common waste materials having lesser neutron moderating and larger neutron capture characteristics. Experience and engineering judgement provide the basis for accepting equivalent subcritical and operational margins for the safety of the plutonium and uranium- 233 values. The uncertainties involved in the calculations are considered small and conservative compared to the variation found in waste matrixes. Also, the methods and assumptions used to calculate subcritical values from the calculated critical values contain sufficient conservatism so that computational uncertainty is not a major factor.

\subsubsection{First Graded Approach}

To calculate the areal densities used in the first graded approach, the method described in NUREG/CR$6284^{1}$ was used. Hypothetical cylinders filled with SNM solution were placed in an infinite planar array. The array was reflected with $240 \mathrm{~cm}(7.9 \mathrm{ft})$ of silicon dioxide on top and bottom. Each cylinder was limited to a subcritical SNM mass, which was calculated for each type of SNM by (1) determining the minimum critical mass for hydrogenous-reflected and moderated spheres, and (2) applying a safety margin of 2.3 to account for accidental double-batching and uncertainties. These mass limits were $350 \mathrm{~g}$ for uranium-235, $250 \mathrm{~g}$ for uranium-233, and $225 \mathrm{~g}$ for plutonium-239. For a given cylinder height/diameter (H/D) ratio and variable SNM solution concentrations, the height and diameter that would contain this subcritical mass were determined. SCALE critical pitch (i.e., center-to-center spacing) searches utilizing CSAS4 and KENO V.a were used to find the array conditions that would produce a $k_{\text {eff }}$ of $1.000 \pm 0.005$. This critical pitch was then used to calculate an average critical areal density for each configuration. The configuration producing the minimum critical areal density served as the basis for the values in the first graded approach. The critical areal densities were reduced by $20 \%$ to produce subcritical values, and then by another $10 \%$ to produce operational values. (The basis for this methodology is given in ref. 1.) Reference 1 provided the data for $100 \mathrm{wt} \%$-enriched uranium, 10 wt \%-enriched uranium, plutonium-239, and the heretofore specified isotopic mixture of plutonium. Additional calculations were performed to provide similar values for uranium-233 in this report. Results are tabulated for the various SNMs in Sect. 7.1.1. The complete data set is given in Appendix B. An example input file is shown in Appendix C.

\subsubsection{Second Graded Approach}

To calculate the SNM concentrations used in the second graded approach, the method described in ref. 2 was used. SCALE calculations utilizing CSAS1X and XSDRNPM were used to determine combinations of silicon dioxide, water and the SNM that are critical in an infinite system. In this case, critical was defined as having a $k_{\text {inf }}>0.95$. (A higher level of uncertainty is associated with these calculations compared with those in Sect. 5.1.2, due to the limited number of critical experiments involving silicon-moderated systems.)

These combinations were then modeled as infinite slabs. SCALE critical dimension searches utilizing CSAS1X were performed to determine the slab thickness that yielded a $k_{\text {eff }}$ of $0.950 \pm 0.001$. (An example input file is shown in Appendix C.) Four meters of reflector were placed on each face of the slabs. The composition of the reflector region matched that of the waste region, except that there was no SNM in the reflector. The density of the silicon dioxide was $1.6 \mathrm{~g} / \mathrm{cm}^{3}$, and the maximum void fraction available for SNM and water together was 0.40 . For a given SNM concentration, the water concentration that provided the minimum critical slab thickness was determined. Reference 2 provided this data for $100 \mathrm{wt} \%$-enriched uranium (ref. 2, Table C-2), and ref. 3 provided this data for $10 \mathrm{wt} \%$ enriched uranium (ref. 3, Table A.1). Additional calculations were performed to provide similar data for uranium-233, plutonium-239, and the isotopic mixture of plutonium in this report. A limited number of calculations with pure plutonium- 241 were 
performed, although it is extremely unlikely for pure plutonium-241 to occur in a waste stream. As discussed in Sect. 1, it is conservative to consider plutonium-241 as plutonium-239 provided that the plutonium-240 concentration is at least as high as the plutonium-241 concentration. ${ }^{4}$ The complete data set for the additional calculations is given in Appendix D.

The SNM concentration required to produce a critical slab of a given thickness was determined from this data.

These concentrations were calculated in units of $\mathrm{g} \mathrm{SNM} / \mathrm{cm}^{3}$ waste and were based on the assumed waste density of $1.6 \mathrm{~g} / \mathrm{cm}^{3}$ (about $100 \mathrm{lb} / \mathrm{ft}^{3}$ ). Because some waste will exceed this density, and in some cases will average about $2.4 \mathrm{~g} / \mathrm{cm}^{3}$ (about $150 \mathrm{lb} / \mathrm{ft}^{3}$ ), the concentrations were adjusted to accommodate this increase. Using the concentration in $\mathrm{g} / \mathrm{cm}^{3}$ and dividing by $2.4 \mathrm{~g}$ waste $/ \mathrm{cm}^{3}$ yields an SNM concentration in $\mathrm{g} \mathrm{SNM/g}$ waste that is a conservative estimate of the critical concentration in a given slab thickness.

In order to account for calculational uncertainty beyond that included in performing critical thickness searches at a $k_{\text {eff }}$ of 0.95 , and to bound operational uncertainties related to determining actual SNM concentrations in the waste, these critical slab concentrations were reduced by a factor of 0.70 to produce operational values. For the chosen emplacement depths (up to $10 \mathrm{ft}$, up to $20 \mathrm{ft}$, and $>20 \mathrm{ft}$ ), the operational values were interpolated from the available data, and are tabulated in Sect. 7.1.2. These operational values at the chosen emplacement depths were checked using SCALE calculations of $k_{\text {eff }}$ using an infinite, silicon dioxide reflected slab, and all of the tabulated systems yield a $k_{\text {eff }}$ of $<0.84$.

\subsubsection{Third Graded Approach}

To calculate the SNM concentrations used in the third graded approach, the method described in Sect. 5.1.3 was altered to include a concrete layer between separate waste regions, and to determine whether segmenting a given emplacement depth into two or three layers would allow for higher SNM concentrations. Such a comparison was made using a model with a single 30-ft-deep emplacement, and comparing results with a model using three 10-ft-deep vaults separated by 16 in. of concrete. This vault dimension was chosen as being representative of vault sizes currently in use, or proposed for future LLW disposal sites (see Sects. 2.2 and 2.3).

Each vault was modeled as an infinite slab having $20.32 \mathrm{~cm}(8 \mathrm{in}$.) of concrete in both the floor and in the ceiling, and having a $3.048 \mathrm{~m}(10-\mathrm{ft})$ inner height. The vaults were stacked, and $4 \mathrm{~m}$ of silicon dioxide reflector was added to the top and bottom of the stack. The same SNM waste matrix was used for this approach, and the data described in Sect. 5.1.3 were used to determine the water concentration that would yield the minimum critical SNM concentration. In the case of $10 \mathrm{wt} \%$-enriched uranium, the minimum critical concentration at around $10-\mathrm{ft}$ slab thicknesses resulted from using $0.03 \mathrm{~g} / \mathrm{cm}^{3}$ water. All of the other SNM combinations were modeled dry. The $\mathrm{SiO}_{2}$ density was $2.4 \mathrm{~g} / \mathrm{cm}^{3}$. SCALE critical concentration searches utilizing CSAS4 and KENO V.a were performed to determine the SNM concentration in the vaults that produced a $k_{\text {eff }}$ of $0.950 \pm 0.005$. (An example input file is shown in Appendix C.) In order to account for calculational uncertainty beyond that included in performing critical concentration searches at a $k_{\text {eff }}$ of 0.95 , and to bound operational uncertainties related to determining actual SNM concentrations in the waste, these critical SNM concentrations were reduced by a factor of 0.70 to produce operational values. The operational values are tabulated in Sect. 7.1.3. These operational values were checked using SCALE calculations of $k_{\text {eff }}$ using an infinite, silicon dioxide-reflected vault stacks, and all tabulated systems yielded a $k_{\text {eff }}$ of less than 0.54 . 


\subsubsection{Uniformity Criteria}

To calculate the area over which the areal density may be averaged, and the mass of waste over which the enrichment or concentration of SNM may be averaged, critical sphere radii were calculated using the method described in ref. 2. Starting with the combinations of silicon dioxide, water and the SNM that were critical in an infinite system as described in Sect. 5.1.3, SCALE critical dimension searches utilizing CSAS1X were performed to determine the spherical radius that yielded a $k_{\text {eff }}$ of $0.950 \pm 0.001$. Four meters of reflector were placed on the sphere surface. The composition of the reflector region matched that of the waste region, except that there was no SNM in the reflector. The density of the silicon dioxide was $1.6 \mathrm{~g} / \mathrm{cm}^{3}$, and the maximum void fraction available for SNM and water together was 0.40 . The critical sphere radius was used to calculate the critical mass of SNM within the sphere. Reference 2 provided these data for $100 \mathrm{wt} \%$ enriched uranium (ref. 2, Table C-2), and ref. 3 provided these data for $10 \mathrm{wt} \%$ enriched uranium (ref. 3, Table A.1). Additional calculations were performed to provide similar data for uranium-233, plutonium-239, plutonium-241, and the isotopic mixture of plutonium in this report. The complete data set for the additional calculations is given in Appendix D.

For each type of SNM, the minimum critical spherical mass for this combination of materials (silicon dioxide, water, and SNM) was determined (see Table 5.1). Note that these masses are somewhat higher than the minimum critical spherical mass for optimumly moderated and reflected SNM metal and water spheres, but such optimum conditions are judged to be highly unlikely in an LLW disposal site. Also, note that these masses were calculated using a silicon dioxide density of $1.6 \mathrm{~g} / \mathrm{cm}^{3}$, because much of the data were taken from previous studies. ${ }^{2,3}$ Performing similar calculations using a higher silicon dioxide density of $2.4 \mathrm{~g} / \mathrm{cm}^{3}$ would produce higher minimum critical spherical masses. These higher masses would result in higher uniformity criteria values that would not be appropriate for the lower-density-waste materials.

Using the operational values for areal density under the first graded approach (see Sect. 7.1.1), the area required to obtain this critical mass for each type of SNM (except plutonium-241) was calculated. The operational areal density value already provides a subcritical margin, so no additional margin was added during this calculation. It was determined that a value of $12 \mathrm{ft}^{2}$ will bound all SNM types described in this report. Therefore, if the areal density for SNM is averaged over no more than $12 \mathrm{ft}^{2}$, it is extremely unlikely that a critical mass of SNM can be concentrated in a small area of the disposal site, while still meeting the areal density value once this mass is averaged over a larger area.

The mass of waste over which enrichment and concentration may be averaged was calculated in a similar way. The concentration values given in Table 7.2 for an up to 10-ft-deep emplacement were adjusted back to a waste density of $1.6 \mathrm{~g} / \mathrm{cm}^{3}$ to be compatible with the minimum critical spherical masses described above. These values were determined by multiplying the values by the ratio (2.4/1.6); the results are shown in Table 5.1. The mass of waste required to obtain the critical spherical mass of SNM was calculated. (The concentration values for a 10-ft emplacement were used to produce a conservative number, because deeper emplacement values would have yielded a higher mass allowable for averaging.) These data are shown in Table 5.1. It was determined that a value of $1500 \mathrm{~kg}$ of waste will bound all SNM types described in this report. Therefore, if the concentration of SNM is averaged over no more than $1500 \mathrm{~kg}$ of waste, it is extremely unlikely that a critical mass of SNM can be concentrated in a small part of the disposal site, while still meeting the operational value once this mass of SNM is averaged over a larger mass of waste. 


\section{Table 5.1 Uniformity criteria}

\begin{tabular}{|c|c|c|c|c|c|}
\hline SNM & $\begin{array}{c}\text { Minimum } \\
\text { spherical } \\
\text { critical mass }\end{array}$ & $\begin{array}{c}\begin{array}{c}\text { Areal density } \\
\text { operational } \\
\text { value }\end{array} \\
\text { (Sect. 7.1.1) }\end{array}$ & $\begin{array}{l}\text { Area needed } \\
\text { to contain } \\
\text { minimum } \\
\text { spherical } \\
\text { critical mass }\end{array}$ & $\begin{array}{c}\text { Adjusted } \\
\text { concentration for } \\
10-\mathrm{ft} \\
\text { emplacement }\end{array}$ & $\begin{array}{l}\text { Mass of waste } \\
\text { needed to } \\
\text { contain } \\
\text { minimum } \\
\text { spherical } \\
\text { critical mass }\end{array}$ \\
\hline Uranium-235 & $1569 \mathrm{~g}{ }^{235} \mathrm{U}$ & $94 \mathrm{~g}{ }^{235} \mathrm{U} / \mathrm{ft}^{2}$ & $16.7 \mathrm{ft}^{2}$ & $8.395 \mathrm{E}-4 \mathrm{~g}{ }^{235} \mathrm{U} / \mathrm{g}$ & $1869 \mathrm{~kg}$ \\
\hline $\begin{array}{l}10 \mathrm{wt} \% \\
\text { Uranium-235 }\end{array}$ & $2428 \mathrm{~g}{ }^{235} \mathrm{U}$ & $174 \mathrm{~g}^{235} \mathrm{U} / \mathrm{ft}^{2}$ & $14.0 \mathrm{ft}^{2}$ & $1.209 \mathrm{E}-3 \mathrm{~g}{ }^{235} \mathrm{U} / \mathrm{g}$ & $2008 \mathrm{~kg}$ \\
\hline Uranium-233 & $1140 \mathrm{~g}{ }^{233} \mathrm{U}$ & $82 \mathrm{~g}^{233} \mathrm{U} / \mathrm{ft}^{2}$ & $13.9 \mathrm{ft}^{2}$ & $\begin{array}{l}6.277 \mathrm{E}-4 \mathrm{~g} \\
{ }^{233} \mathrm{U} / \mathrm{g}\end{array}$ & $1816 \mathrm{~kg}$ \\
\hline Plutonium-239 & $920 \mathrm{~g}{ }^{239} \mathrm{Pu}$ & $52 \mathrm{~g}{ }^{239} \mathrm{Pu} / \mathrm{ft}^{2}$ & $17.7 \mathrm{ft}^{2}$ & $\begin{array}{l}3.838 \mathrm{E}-4 \mathrm{~g} \\
{ }^{239} \mathrm{Pu} / \mathrm{g}\end{array}$ & $2397 \mathrm{~kg}$ \\
\hline Plutonium-241 & $524 \mathrm{~g}{ }^{241} \mathrm{Pu}$ & & & $\begin{array}{l}2.816 \mathrm{E}-4 \mathrm{~g} \\
{ }^{241} \mathrm{Pu} / \mathrm{g}\end{array}$ & $1861 \mathrm{~kg}$ \\
\hline $\begin{array}{l}\text { Plutonium } \\
\text { isotopic mixture }\end{array}$ & $988 \mathrm{~g}{ }^{239} \mathrm{Pu}$ & $51 \mathrm{~g}{ }^{239} \mathrm{Pu} / \mathrm{ft}^{2}$ & $19.4 \mathrm{ft}^{2}$ & $\begin{array}{l}4.324 \mathrm{E}-4 \mathrm{~g} \\
{ }^{239} \mathrm{Pu} / \mathrm{g}\end{array}$ & $2285 \mathrm{~kg}$ \\
\hline
\end{tabular}

\subsection{Assumptions and Limitations}

Silicon dioxide $\left(\mathrm{SiO}_{2}\right)$, or sand, is used in this study as a surrogate for LLW in order to simplify the calculations and provide for a conservative estimate of the critically safe concentration of SNM in LLW. Silicon has a very low-neutron-capture cross section, and silicon dioxide (sand) is often a major constituent in the soil or backfill materials used at LLW facilities. In actual waste disposal environments, neutron absorbers, such as iron, calcium, and sodium, would be expected to be present in the waste, thus making the SNM waste less likely to cause a criticality accident. To ensure that the use of silicon dioxide as a surrogate for LLW would give conservative results, other elements were substituted for the silicon on an atom-for-atom basis in a series of computer calculations. The baseline model was of an infinite dry system containing uranium-235 at a density of $0.00141 \mathrm{~g} / \mathrm{cm}^{3}$ and silicon dioxide at a density of $1.6 \mathrm{~g} / \mathrm{cm}^{3}$, and which had a calculated $k_{\text {inf }}$ of 0.95. SCALE calculations using CSAS1X and cross sections from the 238-group ENDF$\mathrm{B} / \mathrm{V}$ cross-section library were performed, and a comparison was made based on the calculated $k_{\text {inf }}$ of each system. All other elements resulted in a lower value of $k_{i n f}$, with the following exceptions: helium, beryllium, carbon (graphite), fluorine, magnesium, and bismuth (see Appendix E). Restrictions concerning beryllium and graphite are described in Sect. 3.3. Helium, fluorine, magnesium, and bismuth are not expected to be dominant materials in disposal sites, relative to silicon. In particular, fluorine is generally found in chemical compounds with elements that are stronger absorbers of neutrons (e.g., calcium).

Areal densities (grams SNM per unit area, as projected through a volume onto a flat surface) presented under the first graded approach were derived for optimized parameters of SNM concentration, cylinder H/D, 
and array unit pitch. This approach is extremely conservative, because SNM in an LLW disposal facility will not be in such an optimum configuration. The calculation of areal density values also assumed that no single waste package would exceed the limits in 10 CFR Part 150, which are $350 \mathrm{~g}$ of uranium-235, $200 \mathrm{~g}$ of uranium-233, $200 \mathrm{~g}$ of plutonium, or combinations not exceeding the sum-of-fractions rule.

Subcritical enrichment levels presented under the first graded approach were derived using homogeneous mixtures of SNM and water. This approach is also extremely conservative, since pure SNM solutions are not expected to be present in the disposal site.

The values in the second and third graded approaches do not take into account the possibility for significant migration and reconcentration of SNM at a disposal site. As discussed in Sect. 3.2, earlier studies ${ }^{2,3}$ have shown that migration and reconcentration into a configuration posing a potential criticality concern are unlikely occurrences, and may take tens of thousands of years. However, these previous studies did assume that the SNM was not in a highly soluble chemical form (e.g., uranyl nitrate, uranyl fluoride). To account for this assumption, Sect. 7 includes a recommendation that LLW disposal sites minimize the quantity of highly soluble SNM compounds in their waste. 


\section{GRADED APPROACH TO EMPLACEMENT}

Three graded methods of demonstrating subcriticality in emplacement of LLW containing SNM are described below. Even though the emplacement values are higher for the second and third graded approaches, there are assumptions associated with these approaches which limit their applicability.

This report is applicable to SNM-contaminated LLW that meets the following general conditions:

1. The waste does not contain more than $0.1 \mathrm{wt} \%$ of beryllium, graphite, or deuterium.

2. The SNM is homogeneously distributed in the waste or meets the uniformity criteria as described in Sect. 5.1.5.

3. The mass of plutonium-241 does not exceed the mass of plutonium-240.

Although this report is applicable to a range of disposal configurations, there may be conditions at a particular disposal site that warrant a site-specific evaluation. Geological or geochemical conditions at a site may make it unique enough to make such a specific evaluation worthwhile. Highly engineered design features that provide long-term protection of the waste from environmental degradation may allow for higher allowable SNM concentrations in the waste, as may specific waste forms that contain sufficient neutron absorbing materials to make nuclear criticality extremely unlikely. For SNM waste that does not meet the above criteria, then site-specific analysis or reliance on not exceeding the mass limits in 10 CFR Part 150 for a particular vault or disposal unit would be required.

\subsection{First Graded Approach - Areal Density and Enrichment Values}

The first graded-approach method is the most conservative, and may apply to facilities that dispose of very low levels of SNM, or dispose of material with a low average enrichment. It relies on the calculation of average areal density (grams of SNM per square foot), or on the average enrichment of SNM. The area over which averaging may be performed is also specified, but the emplacement depth is not limited.

Waste that contains SNM isotopes at very low enrichments may be disposed of without regard for concentration or areal density. For example, waste contaminated with uranium that has not been enriched in uranium-235 above the natural abundance of approximately $0.71 \mathrm{wt} \%$ may be placed in a disposal site with no regard to concentration. Under conditions normally found in a disposal environment, uranium that is below 0.96 wt $\%$ uranium-235, with the rest being uranium-238, cannot be made critical ${ }^{14}$ Uranium-233 may also be combined with uranium-238 to form a material that cannot be made critical in a disposal environment. ${ }^{15}$ Normal environmental transport mechanisms will not separate fissile from nonfissile isotopes of uranium, so reconcentration of very low-enriched uranium is not an issue. Even though waste that already contains such low enrichments of SNM may be able to use this criteria for safe emplacement, the use of isotopic dilution (addition of uranium-238 to lower the average enrichment of uranium in the waste) that results in a substantial increase in waste volume is not considered a good practice. 


\subsection{Second Graded Approach - SNM Concentration at Limited Emplacement Depth}

The second graded-approach method relies on limiting the average concentration by weight of SNM in the waste, and on limiting the depth of the emplacement. This method may apply to facilities that emplace somewhat higher concentrations of SNM, but do not use vaults or segmentation in the disposal emplacement. Results are tabulated for emplacements that are up to $10 \mathrm{ft}$, up to $20 \mathrm{ft}$, and greater than $20 \mathrm{ft}$ deep. Emplacements greater than $20 \mathrm{ft}$ deep are approaching an "infinite" system from a nuclear criticality perspective.

\subsection{Third Graded Approach - SNM Concentration at Limited Vault Depth}

The third graded-approach method relies on limiting the average concentration by weight of SNM in the waste, and on the presence of segmenting barriers, such as vaults, that will prevent movement of SNM through the barrier. This method may apply to facilities that use concrete vaults in their disposal areas. Results are tabulated for a configuration with 10-ft-tall vaults, with 8-in.-thick concrete floors and ceilings, and stacked three vaults deep. These results are applicable for vaults that are stacked less than three deep, that are less than $10 \mathrm{ft}$ tall, or that have thicker floors or ceilings. 


\section{RECOMMENDATIONS AND OPERATIONAL VALUES}

\subsection{Selection of Graded Approach for a Given Disposal Site}

The graded approachs presented in Sect. 6 are applicable to a wide range of existing and potential disposal practices and site conditions. LLW disposal facilities that place discrete waste packages into trenches, and can, therefore, easily calculate an areal density of the SNM in the trench (e.g., the Richland site), or that dispose of waste containing depleted uranium or other SNM at low enrichment, may be able to use the first graded approach, given in Sect. 7.1.1. LLW disposal facilities that randomly emplace relatively low concentrations of SNM-contaminated LLW (e.g., Envirocare of Utah, Inc.) may be able to use the second graded approach, given in Sect. 7.1.2. Facilities that use engineered design features (e.g., concrete vaults such as those used at the Barnwell site) may be able to justify higher disposal concentrations using the third graded approach. In any case, disposal site designs and operating procedures will be the key to determining which approaches could be used at a given site.

The first step in selecting an approach is to verify that the general conditions presented in Sect. 6 are met. If the waste was shipped as fissile exempt waste under 10 CFR Part 71, it will meet the first condition of containing no more than $0.1 \mathrm{wt} \%$ of beryllium, graphite, or deuterium. If the waste is not fissile exempt waste, the presence of these materials will be shown on the manifest (NRC Form 541). The disposal site operator could contact the waste generator for further information if needed.

Fulfilling the uniformity criteria, as described in Sect. 5.1.5, may be done on a container basis, or for waste that is not disposed of in a container, emplacement records may be used. To average the SNM concentration or enrichment over $1500 \mathrm{~kg}$ of waste, contiguous packages not exceeding a total of $1500 \mathrm{~kg}$ net weight in an emplacement may be averaged. For noncontainerized waste, the SNM concentration or enrichment in any contiguous $1500 \mathrm{~kg}$ of waste in the emplacement should not exceed the given value. Similarly, to average the SNM areal density over $12 \mathrm{ft}^{2}$, the SNM areal density in any contiguous $12 \mathrm{ft}^{2}$ area of the emplacement should not exceed the given value. Each disposal site should develop procedures detailing the method used for averaging and how the records of such averaging are maintained.

Information is provided on NRC Form 541, Item 15, if plutonium-240 or plutonium-241 are present in the waste. The activity in MBq may be converted to a mass of the isotope in grams by dividing by the specific activity (i.e., MBq per grams - See Appendix F). This value will show if the mass of plutonium-241 exceeds that of plutonium-240.

Values are given for some pure SNM isotopes and for some isotopic mixtures. In general, the values for $10 \mathrm{wt} \%$ uranium-235 may be used if the material is $\leq 10 \mathrm{wt} \%$ uranium-235. For material that contains $>10 \mathrm{wt} \%$ uranium-235, the $100 \mathrm{wt} \%$ uranium-235 values should be used. For isotopic mixtures of plutonium, if the material contains $\leq 76 \mathrm{wt} \%$ plutonium- 239 , the isotopic plutonium mixture values may be used. If the material contains greater than $76 \mathrm{wt} \%$ plutonium-239, the values for $100 \mathrm{wt} \%$ plutonium- 239 should be used. In both cases, the plutonium- 241 content must not exceed the plutonium- 240 content. The next step is to verify that any conditions specific to an approach are met. It is envisioned that the first and second graded approaches could be used at most sites. Also, it is possible to use more than a single approach at a site or even within a disposal trench, depending on the characteristics of the waste. After selecting the appropriate graded approach, the next step will be to determine the isotopic composition and enrichment of the waste. Section 7.1.1.2 provides procedures for calculating the enrichment.

In cases where the waste contains a mixture of SNM isotopes, other than $10 \mathrm{wt} \%$-enriched uranium and the isotopic mixture of plutonium included below, a sum-of-fractions rule may be used. The quantity of each SNM type present (i.e., grams of SNM per gram of waste, grams of SNM per square foot) is divided by 
the graded approach value for that type. All of these ratios are then added together, and the sum must not exceed 1. For example, if the waste contains a mixture of uranium-233, uranium-235 and plutonium-239, the following condition must be satisfied:

$$
\frac{{ }^{233} \mathrm{U} \text { quantity }}{{ }^{233} \mathrm{U} \text { value }}+\frac{{ }^{235} \mathrm{U} \text { quantity }}{{ }^{235} \mathrm{U} \text { value }}+\frac{{ }^{239} \mathrm{Pu} \text { quantity }}{{ }^{239} \mathrm{Pu} \text { value }} \leq 1
$$

The values in the equation above will depend upon the chosen graded approach and upon the isotopic composition of the uranium-235 and plutonium-239. The following sections describe in detail how to verify that the graded approach values have been met.

\subsubsection{First Graded Approach}

\subsubsection{Areal Density Values}

Areal density is expressed in terms of mass of SNM per area at the base of the disposal unit. This areal density can also be calculated for a single container using the mass of SNM on the manifest (NRC Form 541, Item 1), dividing by the base area of the container. For example, a 55-gal drum with $104 \mathrm{~g}$ of uranium235 would have an areal density of $36 \mathrm{~g} / \mathrm{f}^{2}$ of uranium-235. If the uranium was enriched to $10 \mathrm{wt} \%$ uranium235 , then no more than four drums could be stacked on top of each other to comply with the value below $\left(174 \mathrm{~g}^{235} \mathrm{U} / \mathrm{ft}^{2}\right)$. The first graded approach does not specify concentration; therefore, waste with concentrations higher than allowed in graded approaches 2 or 3 should be placed in accordance with this graded approach.

As described in Sect. 7.1, the areal density of the waste may be averaged over $12 \mathrm{ft}^{2}$ when determining compliance with the areal density value in Table 7.1. For example, a single 55-gal drum has a base area of approximately $2.9 \mathrm{ft}^{2}$. If this drum contains $350 \mathrm{~g}$ uranium-235, its areal density is $350 \mathrm{~g} / 2.9 \mathrm{ft}^{2}=121 \mathrm{~g} / \mathrm{ft}^{2}$, which exceeds the value in Table 7.1 of $94 \mathrm{~g} / \mathrm{ft}^{2}$. However, in a closely packed triangular-pitched array of drums, $12 \mathrm{ft}^{2}$ of base area can contain three 55-gal drums. Therefore, if one drum contains $350 \mathrm{~g}$ uranium-235, and the remaining two drums contain $200 \mathrm{~g}$ uranium-235 each, the average areal density over the $12 \mathrm{ft}^{2}$ area is $62.5 \mathrm{~g} / \mathrm{ft}^{2}\left(\left((350+200+200) / 12 \mathrm{ft}^{2}\right)=62.5 \mathrm{~g} / \mathrm{ft}^{2}\right)$, which is less than the value in Table 7.1.

To demonstrate the sum-of-fractions rule, suppose one of these three drums also contains $200 \mathrm{~g}$ of uranium-233. The areal density of uranium-233 averaged over the $12 \mathrm{ft}^{2}$ area is $17 \mathrm{~g} / \mathrm{ft}^{2}$. The sum-of-fractions rule would be the following:

$$
\frac{\text { uranium }-233 \text { quantity }}{\text { uranium }-233 \text { value }}+\frac{\text { uranium }-235 \text { quantity }}{\text { uranium }-235 \text { value }}=\frac{17}{82}+\frac{62.5}{94}=0.87 \text {. }
$$

The sum is $<1$, so this combination is in agreement with the areal density values in Table 7.1.

If the first graded approach is used, LLW facilities should develop operating procedures to track the location of SNM waste within the disposal unit, to verify the areal density values have been met, and to prevent additional placement of SNM waste above areas where the areal density values have been reached. 
Table 7.1 Areal density values

\begin{tabular}{|c|c|}
\hline SNM & Operational value ${ }^{a}$ \\
\hline $100 \mathrm{wt} \%$ enriched uranium & $94 \mathrm{~g}{ }^{235} \mathrm{U} / \mathrm{ft}^{2}$ \\
\hline $10 \mathrm{wt} \%$ enriched uranium & $174 \mathrm{~g}^{235} \mathrm{U} / \mathrm{ft}^{2}$ \\
\hline Uranium-233 & $82 \mathrm{~g}{ }^{233} \mathrm{U} / \mathrm{ft}^{2}$ \\
\hline Plutonium-239 & $52 \mathrm{~g}{ }^{239} \mathrm{Pu} / \mathrm{ft}^{2}$ \\
\hline $\begin{array}{l}\text { Isotopic mixture of plutonium } \\
\text { ( } 76 \mathrm{wt} \% \text { plutonium-239, } 12 \mathrm{wt} \% \text { plutonium-240, and } 12 \mathrm{wt} \% \text { plutonium-241) }\end{array}$ & $51 \mathrm{~g}^{239} \mathrm{Pu} / \mathrm{ft}^{2}$ \\
\hline
\end{tabular}

${ }^{a}$ The areal density in $\mathrm{kg} / \mathrm{m}^{2}$ can be obtained by multiplying the $\mathrm{g} / \mathrm{ft}^{2}$ values by 0.010763 .

\subsubsection{Subcritical Enrichment Levels for Different SNM Isotopes}

Enrichment is a ratio of the weight of uranium-235 or uranium-233 to total uranium, and is typically expressed as a percent. This enrichment (wt \%) can be calculated using information on the manifest. The activity of uranium-238 in MBq, if present, would be recorded on the manifest (NRC Form 541, Item 15). The activity should be converted to a mass of the isotope by dividing by the specific activity (i.e., MBq per grams See Appendix F). The mass of SNM isotopes can be obtained directly from the manifest (NRC Form 541, Item 1). The enrichment can then be calculated using the masses of the required isotopes. Waste containing SNM at or below the enrichments listed below may be placed in a disposal site without concern for a nuclear criticality accident.

$$
\begin{aligned}
& \text { Uranium-235 }=0.96 \mathrm{wt} \% \\
& \text { Uranium-233 }=0.66 \mathrm{wt} \%
\end{aligned}
$$

The uranium enrichment of waste may be averaged over no more than $1500 \mathrm{~kg}$ of waste in order to meet these criteria. For example, consider a 55-gal drum containing $350 \mathrm{~kg}$ (772 lb) of waste contaminated with $100 \mathrm{~g}$ of uranium-233 at an enrichment of $1.5 \mathrm{wt} \%$. This drum would then contain over $6.6 \mathrm{~kg}$ of uranium-238. (The quantities of uranium-233 and uranium-238 can be taken from the NRC Form 541 information, as described above.) If three adjacent drums in the emplacement each contain $350 \mathrm{~kg}$ of waste contaminated with $100 \mathrm{~g}$ of uranium-233 at an enrichment of $0.4 \mathrm{wt} \%$, each of these drums would, therefore, contain $25 \mathrm{~kg}$ of uranium-235. The total mass of uranium- 233 in these four drums would be $400 \mathrm{~g}$, and the total mass of uranium- 238 would be $81.6 \mathrm{~kg}$, making the average uranium- 233 enrichment $0.49 \mathrm{wt} \%$.

$$
\frac{400 \mathrm{~g} \text { uranium }-233}{400 \mathrm{~g} \text { uranium }-233+81,600 \mathrm{~g} \text { uranium }-238} \times 100 \%=0.49 \text { wt } \% \text {. }
$$

The total mass of waste in these four drums would be $1400 \mathrm{~kg}$. Therefore, these four drums averaged together meet the subcritical enrichment criteria for the first graded approach. 


\subsubsection{Second Graded Approach}

Concentration in this approach is expressed in terms of mass of SNM per mass of waste. This value can be calculated using information on the manifest. The mass of SNM isotopes is recorded on NRC Form 541, Item 1, and the mass of the waste is recorded on NRC Form 541, Item 8. The concentration is calculated by dividing the mass of the SNM by the mass of the waste. As discussed in Sect. 5.1, the concentration should be averaged over no more than $1500 \mathrm{~kg}$ of waste.

For example, consider a 25 -ft waste emplacement with a 55 -gal drum, containing $350 \mathrm{~kg}$ (772 lb) of waste contaminated with $200 \mathrm{~g}$ of uranium-233. The concentration of uranium-233 in this drum is $5.74 \mathrm{E}-4$ g uranium-233/g waste, which exceeds the value in Table 7.2. If three adjacent drums in the emplacement each contain $350 \mathrm{~kg}$ of waste contaminated with $75 \mathrm{~g}$ of uranium-233, the average concentration over these four drums would be $3.036 \mathrm{E}-4 \mathrm{~g}$ uranium-233/g waste, which is less than the value in Table 7.2. Therefore, these four drums averaged together meet the criteria for the second graded approach.

If the second graded approach is used, LLW facilities should develop operating procedures to document that the concentration of SNM waste does not exceed these values. The appropriate concentration value should be selected from the following table based in the depth of the disposal unit.

Table 7.2 Second graded-approach values

\begin{tabular}{|c|c|c|c|}
\hline SNM & $\begin{array}{l}\text { Up-to-10-ft } \\
\text { emplacement }\end{array}$ & $\begin{array}{l}\text { Up-to-20-ft } \\
\text { emplacement }\end{array}$ & $\begin{array}{l}\text { Greater than } 20-\mathrm{ft} \\
\text { emplacement }\end{array}$ \\
\hline $100 \mathrm{wt} \%$ enriched uranium & $5.597 \mathrm{E}-4 \mathrm{~g}^{235} \mathrm{U} / \mathrm{g}$ & $4.706 \mathrm{E}-4 \mathrm{~g}{ }^{235} \mathrm{U} / \mathrm{g}$ & $4.592 \mathrm{E}-4 \mathrm{~g}{ }^{235} \mathrm{U} / \mathrm{g}$ \\
\hline 10 wt $\%$ enriched uranium & $8.060 \mathrm{E}-4 \mathrm{~g}{ }^{235} \mathrm{U} / \mathrm{g}$ & $7.107 \mathrm{E}-4 \mathrm{~g}{ }^{235} \mathrm{U} / \mathrm{g}$ & $6.933 \mathrm{E}-4 \mathrm{~g}{ }^{235} \mathrm{U} / \mathrm{g}$ \\
\hline Uranium-233 & $4.185 \mathrm{E}-4 \mathrm{~g}{ }^{233} \mathrm{U} / \mathrm{g}$ & $3.573 \mathrm{E}-4 \mathrm{~g}{ }^{233} \mathrm{U} / \mathrm{g}$ & $3.444 \mathrm{E}-4 \mathrm{~g}{ }^{233} \mathrm{U} / \mathrm{g}$ \\
\hline Plutonium-239 & $2.559 \mathrm{E}-4 \mathrm{~g}{ }^{239} \mathrm{Pu} / \mathrm{g}$ & $2.035 \mathrm{E}-4 \mathrm{~g}{ }^{239} \mathrm{Pu} / \mathrm{g}$ & $1.961 \mathrm{E}-4 \mathrm{~g}{ }^{239} \mathrm{Pu} / \mathrm{g}$ \\
\hline Plutonium-241 & $1.877 \mathrm{E}-4 \mathrm{~g}{ }^{241} \mathrm{Pu} / \mathrm{g}$ & $1.566 \mathrm{E}-4 \mathrm{~g}{ }^{241} \mathrm{Pu} / \mathrm{g}$ & $1.496 \mathrm{E}-4 \mathrm{~g}{ }^{241} \mathrm{Pu} / \mathrm{g}$ \\
\hline $\begin{array}{l}\text { Isotopic mixture of plutonium } \\
\text { ( } 76 \mathrm{wt} \% \text { plutonium- } 239 \text {, } \\
12 \mathrm{wt} \% \text { plutonium-240, and } \\
12 \mathrm{wt} \% \text { plutonium-241) }\end{array}$ & 2.883E-4 $\mathrm{g}^{239} \mathrm{Pu} / \mathrm{g}$ & $2.256 \mathrm{E}-4 \mathrm{~g}{ }^{239} \mathrm{Pu} / \mathrm{g}$ & $2.102 \mathrm{E}-4 \mathrm{~g}{ }^{239} \mathrm{Pu} / \mathrm{g}$ \\
\hline
\end{tabular}




\subsubsection{Third Graded Approach}

As in Sect. 7.1.2, the concentration in this approach is expressed in terms of mass of SNM per mass of waste. This value can be calculated using information on the manifest. The mass of SNM isotopes is recorded on NRC Form 541, Item 1, and the mass of the waste is recorded on NRC Form 541, Item 8 . The concentration is calculated by dividing the mass of the SNM by the mass of the waste. As discussed in Sect. 5.1, the concentration should be averaged over no more than $1500 \mathrm{~kg}$ of waste. An example of such averaging is given in Sect. 7.1.2.

If the third graded approach is used, LLW facilities should develop operating procedures to document that the concentration of SNM waste does not exceed the values in Table 7.3.

Table 7.3 Third graded-approach values

\begin{tabular}{lc}
\hline \multicolumn{1}{c}{ SNM } & $\begin{array}{c}\text { Concentration for } 3 \times 10 \mathrm{ft} \text { vaults } \\
\text { as described }\end{array}$ \\
\hline 100 wt \% enriched uranium & $7.407 \mathrm{E}-4 \mathrm{~g}{ }^{235} \mathrm{U} / \mathrm{g}$ \\
$10 \mathrm{wt} \%$ enriched uranium & $1.168 \mathrm{E}-3 \mathrm{~g}{ }^{235} \mathrm{U} / \mathrm{g}$ \\
Uranium-233 & $5.516 \mathrm{E}-4 \mathrm{~g}{ }^{233} \mathrm{U} / \mathrm{g}$ \\
Plutonium-239 & $3.304 \mathrm{E}-4 \mathrm{~g}{ }^{239} \mathrm{Pu} / \mathrm{g}$ \\
Isotopic mixture of plutonium & $3.748 \mathrm{E}-4 \mathrm{~g}{ }^{239} \mathrm{Pu} / \mathrm{g}$ \\
\hline (76 wt \% plutonium-239, 12 wt \% plutonium-240, and & \\
\hline 12 wt \% plutonium-241) & \\
\hline
\end{tabular}

\subsection{LLW Emplacement Good Practices}

As discussed in Sect. 3.2, SNM migration and reconcentration is an issue that is not addressed by this report. Earlier studies ${ }^{2,3}$ provide data that indicate that SNM migration and reconcentration into a potentially critical configuration is unlikely and would take tens of thousands of years. Engineered design features can be used to mitigate such movement and to detect an increase in SNM within nearby groundwater before significant migration occurs.

Several factors affect SNM migration or concentration. These include the amount of water entering the disposal unit, the chemistry of the waste and water, and the presence of preferential pathways (e.g., drains, sumps, etc.). To minimize the potential for migration, and to maximize the probability of detecting migration before it becomes significant, the following good practices should be incorporated:

- Infiltration of rain or groundwater should be minimized to lengthen the life of the disposal containers and to limit the volume of water available to move the uranium from its disposal location. Unsaturated conditions greatly reduce opportunities for migration and concentration. 
- Highly soluble chemical forms of SNM should be minimized in a disposal site. Examples of soluble compounds include uranyl nitrate and uranyl fluoride, which are common chemical forms of uranium in waste from fuel processing facilities.

- Facility designs should minimize preferential pathways that would tend to concentrate or focus effluents. The use of sumps or other means of sampling the water below the LLW emplacement will provide a means of detecting migration before it becomes significant. However, the geometry and size of such collection points should be restricted to avoid potential critical geometries.

- LLW emplacements should minimize zones with strong reducing potential. Uranium compounds tend to become more soluble in oxidizing conditions, and precipitate under reducing conditions ${ }^{16}$ Rainwater tends to be oxidizing, thus is capable of dissolving uranium and transporting it through a disposal site. Organic materials and iron tend to be reducing, so uranium in solution may precipitate when it encounters these materials, forming a reconcentration zone that could pose the potential for a nuclear criticality accident. Limiting rainwater infiltration will also help in keeping the SNM from oxidizing and dissolving.

- Where operationally feasible, the areal density of SNM should be as low as is practical; that is, SNM waste containers should not be stacked and should be placed as far from other SNM containers as is practical.

- Where operationally feasible, the enrichment of SNM should be reduced; that is, depleted uranium, natural uranium, or natural thorium should be placed adjacent to SNM waste.

- Void space between SNM containers should be backfilled with sand or grout to minimize post disposal settling. 


\section{REFERENCES}

1. C. M. Hopper, R. H. Odegaarden, C. V. Parks, and P. B. Fox, Criticality Safety Criteria for License Review of Low-Level Waste Facilities, NUREG/CR-6284 (ORNL/TM-12845), U.S. Nuclear Regulatory Commission, Oak Ridge National Laboratory, March 1995.

2. L. E. Toran, C. M. Hopper, M. T. Naney, C. V. Parks, J. F. McCarthy, B. L. Broadhead, and V. A. Colten-Bradley, The Potential for Criticality Following Disposal of Uranium at Low-Level Waste Facilities, Volume 1: Uranium Blended with Soil, NUREG/CR-6505, Vol. 1 (ORNL/TM-13323/V1), U.S. Nuclear Regulatory Commission, Oak Ridge National Laboratory, June 1997.

3. L. E. Toran, C. M. Hopper, C. V. Parks, and V. A. Colten-Bradley, The Potential for Criticality Following Disposal of Uranium at Low-Level Waste Facilities, Volume 2: Containerized Disposal, NUREG/CR-6505, Vol. 2 (ORNL/TM-13323/V2), U.S. Nuclear Regulatory Commission, Oak Ridge National Laboratory, June 1999.

4. H. K. Clark, H.K., "Subcritical Limits for Special Fissile Actinides," Nucl. Technol., 48, 164 (1980).

5. S. Glasstone and A. Sesonske, Nuclear Reactor Engineering, $3^{\text {rd }}$ ed., Van Nostrand Reinhold Company, New York, 1981.

6. Committee to Provide Interim Oversight of the DOE Nuclear Weapons Complex, Richard A. Meserve, Chairman, The Nuclear Weapons Complex: Management for Health, Safety, and the Environment, National Academy Press, Washington, D.C., 1989.

7. C. V. Parks, C. M. Hopper, and J. J. Lichtenwalter, Assessment and Recommendations for FissileMaterial Packaging Exemptions and General Licenses Within 10 CFR Part 71, NUREG/CR-5342 (ORNL/TM-13607), U.S. Nuclear Regulatory Commission, Oak Ridge National Laboratory, July 1998.

8. H. C. Paxton, Correlations of Experimental and Theoretical Critical Data Comparative Reliability Safety Factors for Criticality Control, LA-2537-MS, Los Alamos Scientific Lab., March 1961.

9. H. C. Paxton, Criticality Control in Operation with Fissile Material, LA-3366-Rev, Los Alamos Scientific Lab., November 1972.

10. R. L. Stevenson and R. H. Odegaarden, "Studies of Surface Density Spacing Criteria Using KENO Calculations," originally prepared circa 1970 by the Division of Materials Licensing, U.S. Atomic Energy Commission. Available as Appendix A of the Safety Evaluation Report for the Barnwell Low-Level Waste Site, License No. 12-13536-01, Amendment 23, U.S. Nuclear Regulatory Commission (April 1991).

11. SCALE: A Modular Code System for Performing Standardized Computer Analyses for Licensing Evaluations, NUREG/CR-0200, Rev. 4 (ORNL/NUREG/CSD-2/R4), Vols. I, II, and III, April 1995. Available from Radiation Safety Information Computational Center at Oak Ridge National Laboratory as CCC-545. 
12. SCALE: A Modular Code System for Performing Standardized Computer Analyses for Licensing Evaluations, NUREG/CR-0200, Rev. 5 (ORNL/NUREG/CSD-2/R5), Vols. I, II, and III, March 1997. Available from Radiation Safety Information Computational Center at Oak Ridge National Laboratory as CCC-545.

13. W. C. Jordan, N. F. Landers, and L. M. Petrie, Validation of KENO V.a Comparison with Critical Experiments, ORNL/CSD/TM-238, Martin Marietta Energy Systems, Inc., Oak Ridge National Laboratory, December 1986.

14. American National Standard for Nuclear Criticality Safety in Operations with Fissionable Material Outside Reactors, ANSI/ANS-8.1-1998, American Nuclear Society, 555 North Kensington Avenue, La Grange Park, Illinois 60525, USA.

15. K. R. Elam, C. W. Forsberg, C. M. Hopper, and R. Q. Wright, Isotopic Dilution Requirements for ${ }^{233} U$ Criticality Safety in Processing and Disposal Facilities, ORNL/TM-13524, Lockheed Martin Energy Research Corporation., Oak Ridge National Laboratory, November 1997.

16. C. W. Forsberg, "Long-Term Criticality Control in Radioactive Waste Disposal Facilities," Nuclear Safety 38(1), 60-69 (1997). 
APPENDIX A

\section{VERIFICATION OF KENO V.A CALCULATION $\mathrm{OF} \mathrm{SIO}_{2} / \mathrm{SNM}$ SYSTEMS}




\section{APPENDIX A}

\section{VERIFICATION OF KENO V.A CALCULATION $\mathrm{OF} \mathrm{SIO}_{2} / \mathrm{SNM}$ SYSTEMS}

While the SCALE computer code system and the neutron cross-section libraries that were used have been extensively validated against many critical benchmark experiments, there are not many documented critical experiments utilizing SNM and $\mathrm{SiO}_{2}$ systems. Recently published critical experiments performed at the Institute of Physics and Power Engineering (IPPE) within the Russian Federation ${ }^{\mathrm{d}}$ allow for verification that the SCALE computer code system and libraries do a reasonably good job of calculating $\mathrm{SNM}$ and $\mathrm{SiO}_{2}$ models with variable levels of moderation. Two series of experiments were performed by IPPE, one with highly enriched uranium and one with plutonium.

The experiments with highly enriched uranium consisted of five critical configurations with heterogeneous compositions of highly enriched uranium, silicon dioxide, and polyethylene. The critical assemblies were composed of sets of aluminum tubes $(5.0 \mathrm{~cm}$ in outer diameter, $0.1 \mathrm{~cm}$ wall thickness, and about $2 \mathrm{~m}$ long) filled with pellets of highly enriched uranium metal in aluminum cans, silicon dioxide, and polyethylene. Also, quartz (silicon dioxide) sand was used to fill tubes in the reflector at the core periphery. Thin polyethylene dowels were inserted into the space between the tubes in some cases, to provide well-defined moderation similar to water. The pitch of the hexagonal lattice of the tubes was $5.1 \mathrm{~cm}$. The entire core was approximately $2 \mathrm{~m}$ in diameter.

Using the same suite of SCALE codes and neutron cross-section libraries that were used for developing the graded approach values, the experiments utilizing highly enriched uranium were calculated. These experiments span a fairly wide range of moderation levels and neutron energy spectra, as shown in Table A.1. These significant variations in neutron energy spectra are representative of contaminated soils with varying water moisture content. Those calculations confirm that the computational biases for variably moderated "soil like" systems that are contaminated with uranium are relatively small (i.e., calculated $k_{\text {eff }}$ divided by benchmark $k_{\text {eff }}$ ratios very close to 1.00$)$.

Table A.1 Comparison of calculated $k_{\text {eff }}$ to benchmark $k_{\text {eff }}$

\begin{tabular}{ccc}
\hline BFS79 Case number & $\begin{array}{c}\text { Energy of average lethargy } \\
\text { causing fission }(\mathrm{eV})\end{array}$ & $\begin{array}{c}\text { Calculated } k_{\text {eff }} / \\
\text { benchmark } k_{\text {eff }}\end{array}$ \\
\hline 1 & 43 & 0.9981 \\
2 & 11 & 1.0031 \\
3 & 2 & 0.9964 \\
4 & 178 & 1.0041 \\
5 & 5200 & 0.9944 \\
\hline
\end{tabular}

${ }^{d}$ Critical Experiments with Heterogeneous Compositions of Highly Enriched Uranium, Silicon Dioxide, and Polyethylene, HEU-MET-MIXED-005 in International Handbook of Evaluated Criticality Safety Benchmark Experiments, NEA/NSC/DOC(95)03/II, Nuclear Energy Agency, Organization for Economic Co-operation and Development, Paris, France (September 2000). 


\section{APPENDIX B}

\section{DATA FOR FIRST GRADED-APPROACH METHOD}




\section{APPENDIX B}

\section{DATA FOR FIRST GRADED-APPROACH METHOD}

Table B.1 100 wt $\%$ enriched uranium hydrogenous systems, $\mathrm{SiO}_{2}(\rho=1.9)$-reflected (Z-axis) 350 g uranium-235 per unit, infinite planar array

\begin{tabular}{|c|c|c|c|c|c|}
\hline $\mathrm{H} / \mathrm{D}$ & $\mathrm{g}{ }^{235} \mathrm{U} / \mathrm{L}$ & Pitch $(\mathrm{cm})$ & $k_{\text {eff }}$ & $\sigma$ & {$\left[\mathrm{g}{ }^{235} \mathrm{U} / \mathrm{ft}^{2}\right]^{a}$} \\
\hline \multirow[t]{5}{*}{0.5} & 100 & 41.570 & 0.9976 & 0.0017 & 188 \\
\hline & 75 & 44.478 & 1.0008 & 0.0017 & 164 \\
\hline & 50 & 47.292 & 1.0035 & 0.0017 & 145 \\
\hline & 35 & 46.044 & 1.0004 & 0.0014 & 153 \\
\hline & 25 & 41.012 & 0.9997 & 0.0012 & 193 \\
\hline \multirow[t]{5}{*}{1.0} & 100 & 43.066 & 1.0034 & 0.0027 & 175 \\
\hline & 75 & 45.826 & 1.0024 & 0.0026 & 155 \\
\hline & 50 & 49.716 & 0.9960 & 0.0023 & 132 \\
\hline & 35 & 48.946 & 0.9995 & 0.0021 & 136 \\
\hline & 25 & 43.324 & 1.0018 & 0.0018 & 173 \\
\hline \multirow[t]{5}{*}{1.5} & 100 & 43.288 & 0.9966 & 0.0026 & 174 \\
\hline & 75 & 45.636 & 1.0033 & 0.0026 & 156 \\
\hline & 50 & 48.898 & 1.0040 & 0.0024 & 136 \\
\hline & 35 & 48.704 & 0.9968 & 0.0021 & 137 \\
\hline & 25 & 43.288 & 1.0037 & 0.0017 & 174 \\
\hline \multirow[t]{5}{*}{2.0} & 100 & 42.110 & 1.0036 & 0.0029 & 183 \\
\hline & 75 & 45.738 & 0.9969 & 0.0025 & 155 \\
\hline & 50 & 48.404 & 1.0028 & 0.0023 & 139 \\
\hline & 35 & 47.890 & 1.0000 & 0.0022 & 142 \\
\hline & 25 & 43.142 & 1.0030 & 0.0018 & 175 \\
\hline \multirow[t]{5}{*}{2.5} & 100 & 42.526 & 0.9965 & 0.0026 & 180 \\
\hline & 75 & 45.222 & 0.9984 & 0.0024 & 159 \\
\hline & 50 & 48.192 & 0.9972 & 0.0022 & 140 \\
\hline & 35 & 46.916 & 1.0045 & 0.0020 & 148 \\
\hline & 25 & 42.870 & 1.0012 & 0.0019 & 177 \\
\hline
\end{tabular}

${ }^{a}$ The areal density in $\mathrm{kg} / \mathrm{m}^{2}$ can be obtained by multiplying the $\mathrm{g} / \mathrm{ft}^{2}$ values by 0.010763 . 
Table B.2 10 wt \% enriched uranium systems, $\mathrm{SiO}_{2}(\rho=1.9)$-reflected (Z-axis) $35 \mathrm{~g}$ uranium-235 per unit, infinite planar array

\begin{tabular}{|c|c|c|c|c|c|}
\hline $\mathrm{H} / \mathrm{D}$ & $\mathrm{g}{ }^{235} \mathrm{U} / \mathrm{L}$ & Pitch $(\mathrm{cm})$ & $k_{e f f}$ & $\sigma$ & {$\left[\mathrm{g}{ }^{235} \mathrm{U} / \mathrm{ft}^{2}\right]^{a}$} \\
\hline \multirow[t]{5}{*}{1.0} & 100 & 10.508 & 0.9969 & 0.0023 & 294 \\
\hline & 75 & 11.057 & 0.9994 & 0.0021 & 266 \\
\hline & 50 & 11.470 & 1.0000 & 0.0020 & 247 \\
\hline & 35 & 11.520 & 0.9956 & 0.0019 & 245 \\
\hline & 25 & & not critical & & \\
\hline \multirow[t]{5}{*}{2.0} & 100 & 10.482 & 0.9991 & 0.0023 & 295 \\
\hline & 75 & 11.172 & 0.9962 & 0.0020 & 260 \\
\hline & 50 & 11.585 & 1.0008 & 0.0018 & 242 \\
\hline & 35 & 11.469 & 0.9955 & 0.0018 & 247 \\
\hline & 25 & 10.697 & 0.9971 & 0.0016 & 284 \\
\hline \multirow[t]{5}{*}{4.0} & 100 & 10.487 & 0.9991 & 0.0023 & 295 \\
\hline & 75 & 11.042 & 1.0043 & 0.0021 & 266 \\
\hline & 50 & 11.559 & 0.9999 & 0.0020 & 243 \\
\hline & 35 & 11.401 & 1.0007 & 0.0017 & 250 \\
\hline & 25 & 10.578 & 1.0005 & 0.0016 & 290 \\
\hline \multirow[t]{5}{*}{6.0} & 100 & 10.421 & 1.0044 & 0.0021 & 299 \\
\hline & 75 & 11.063 & 0.0079 & 0.0021 & 265 \\
\hline & 50 & 11.574 & 0.9976 & 0.0019 & 242 \\
\hline & 35 & 11.420 & 1.0006 & 0.0017 & 249 \\
\hline & 25 & 10.535 & 0.9986 & 0.0015 & 293 \\
\hline
\end{tabular}

${ }^{a}$ The areal density in $\mathrm{kg} / \mathrm{m}^{2}$ can be obtained by multiplying the $\mathrm{g} / \mathrm{ft}^{2}$ values by 0.010763 . 
Table B.3 Uranium-233 hydrogenous systems, $\mathrm{SiO}_{2}(\rho=1.9)$-reflected (Z-axis) $250 \mathrm{~g}$ uranium-233 per unit, infinite planar array

\begin{tabular}{|c|c|c|c|c|c|}
\hline $\mathrm{H} / \mathrm{D}$ & $\mathrm{g}{ }^{233} \mathrm{U} / \mathrm{L}$ & Pitch (cm) & $k_{e f f}$ & $\sigma$ & {$\left[\mathrm{g}{ }^{233} \mathrm{U} / \mathrm{ft}^{2}\right]^{a}$} \\
\hline \multirow[t]{5}{*}{0.5} & 100 & 39.102 & 1.0007 & 0.0022 & 152 \\
\hline & 75 & 41.762 & 1.0018 & 0.0020 & 133 \\
\hline & 50 & 43.530 & 0.9978 & 0.0017 & 123 \\
\hline & 35 & 42.656 & 0.9956 & 0.0016 & 128 \\
\hline & 25 & 38.096 & 0.9978 & 0.0013 & 160 \\
\hline \multirow[t]{8}{*}{1.0} & 100 & 40.000 & 1.0008 & 0.0019 & 145 \\
\hline & 75 & 42.804 & 1.0029 & 0.0021 & 127 \\
\hline & 60 & 44.268 & 1.0004 & 0.0019 & 119 \\
\hline & 50 & 45.056 & 0.9978 & 0.0018 & 114 \\
\hline & 45 & 45.212 & 1.0000 & 0.0017 & 114 \\
\hline & 40 & 44.838 & 0.9975 & 0.0017 & 116 \\
\hline & 35 & 44.634 & 1.0026 & 0.0016 & 117 \\
\hline & 25 & 40.000 & 1.0042 & 0.0013 & 145 \\
\hline \multirow[t]{5}{*}{1.5} & 100 & 40.000 & 0.9972 & 0.0020 & 145 \\
\hline & 75 & 42.484 & 1.0005 & 0.0020 & 129 \\
\hline & 50 & 44.956 & 1.0034 & 0.0018 & 115 \\
\hline & 35 & 44.082 & 0.9993 & 0.0017 & 120 \\
\hline & 25 & 40.000 & 1.0045 & 0.0013 & 145 \\
\hline \multirow[t]{5}{*}{2.0} & 100 & 39.924 & 0.9986 & 0.0019 & 146 \\
\hline & 75 & 41.950 & 1.0000 & 0.0020 & 132 \\
\hline & 50 & 44.282 & 1.0002 & 0.0018 & 118 \\
\hline & 35 & 43.536 & 0.9992 & 0.0016 & 123 \\
\hline & 25 & 40.000 & 1.0005 & 0.0012 & 145 \\
\hline \multirow[t]{5}{*}{2.5} & 100 & 38.986 & 1.0009 & 0.0019 & 153 \\
\hline & 75 & 41.396 & 1.0003 & 0.0020 & 136 \\
\hline & 50 & 43.404 & 0.9971 & 0.0019 & 123 \\
\hline & 35 & 43.494 & 1.0032 & 0.0016 & 123 \\
\hline & 25 & 40.000 & 0.9952 & 0.0014 & 145 \\
\hline
\end{tabular}

${ }^{a}$ The areal density in $\mathrm{kg} / \mathrm{m}^{2}$ can be obtained by multiplying the $\mathrm{g} / \mathrm{ft}^{2}$ values by 0.010763 . 
Table B.4 Plutonium-239 hydrogenous systems, $\mathrm{SiO}_{2}(\rho=1.9)$-reflected (Z-axis) 225 g plutonium-239 per unit, infinite planar array

\begin{tabular}{|c|c|c|c|c|c|}
\hline $\mathrm{H} / \mathrm{D}$ & $\mathrm{g}{ }^{239} \mathrm{Pu} / \mathrm{L}$ & Pitch $(\mathrm{cm})$ & $k_{\text {eff }}$ & $\sigma$ & {$\left[\mathrm{g}^{239} \mathrm{Pu} / \mathrm{ft}^{2}\right]^{a}$} \\
\hline \multirow[t]{7}{*}{1.0} & 100 & 37.822 & 0.9973 & 0.0028 & 146 \\
\hline & 75 & 41.856 & 1.0041 & 0.0028 & 119 \\
\hline & 50 & 47.206 & 1.0030 & 0.0026 & 93 \\
\hline & 35 & 51.490 & 1.0037 & 0.0026 & 79 \\
\hline & 25 & 53.390 & 0.9996 & 0.0021 & 73 \\
\hline & 20 & 52.302 & 0.9977 & 0.0019 & 76 \\
\hline & 15 & 46.748 & 1.0038 & 0.0020 & 96 \\
\hline \multirow[t]{8}{*}{2.0} & 100 & 37.366 & 1.0038 & 0.0026 & 150 \\
\hline & 75 & 41.334 & 1.0011 & 0.0028 & 122 \\
\hline & 50 & 46.592 & 1.0040 & 0.0027 & 96 \\
\hline & 35 & 50.652 & 0.9980 & 0.0022 & 81 \\
\hline & 25 & 51.932 & 1.0039 & 0.0022 & 78 \\
\hline & 20 & 51.356 & 0.9976 & 0.0019 & 79 \\
\hline & 15 & 47.326 & 0.9968 & 0.0019 & 93 \\
\hline & 10 & 33.528 & 1.0017 & 0.0013 & 186 \\
\hline \multirow[t]{6}{*}{2.5} & 50 & 46.224 & 1.0014 & 0.0026 & 98 \\
\hline & 35 & 49.852 & 1.0019 & 0.0024 & 84 \\
\hline & 25 & 51.478 & 0.9987 & 0.0021 & 79 \\
\hline & 20 & 50.298 & 0.9995 & 0.0021 & 83 \\
\hline & 15 & 46.428 & 1.0001 & 0.0019 & 97 \\
\hline & 10 & 33.508 & 1.0013 & 0.0014 & 186 \\
\hline
\end{tabular}

${ }^{a}$ The areal density in $\mathrm{kg} / \mathrm{m}^{2}$ can be obtained by multiplying the $\mathrm{g} / \mathrm{ft}^{2}$ values by 0.010763 . 
Table B.5 Plutonium isotopic mixture ${ }^{a}$ hydrogenous systems, $\mathrm{SiO}_{2}(\rho=1.9)$-reflected (Z-axis), 225 g plutonium-239 per unit, infinite planar array

\begin{tabular}{|c|c|c|c|c|c|c|}
\hline $\mathrm{H} / \mathrm{D}$ & $\mathrm{g}{ }^{239} \mathrm{Pu} / \mathrm{L}$ & Pitch $(\mathrm{cm})$ & $k_{\text {eff }}$ & $\sigma$ & {$\left[\mathrm{g}{ }^{239} \mathrm{Pu} / \mathrm{ft}^{2}\right]^{a}$} & {$\left[\mathrm{~g}\left({ }^{239} \mathrm{Pu}+{ }^{241} \mathrm{Pu}\right) / \mathrm{ft}^{2}\right]^{b}$} \\
\hline \multirow[t]{7}{*}{1.0} & 100 & 33.870 & 0.9968 & 0.0029 & 182 & 211 \\
\hline & 75 & 38.318 & 0.9988 & 0.0026 & 142 & 164 \\
\hline & 50 & 44.568 & 1.0005 & 0.0023 & 105 & 122 \\
\hline & 35 & 49.422 & 1.0043 & 0.0025 & 86 & 100 \\
\hline & 25 & 52.532 & 1.0050 & 0.0022 & 76 & 88 \\
\hline & 20 & 53.912 & 0.9990 & 0.0021 & 72 & 83 \\
\hline & 15 & 51.888 & 0.9981 & 0.0018 & 78 & 90 \\
\hline \multirow[t]{8}{*}{2.0} & 100 & 33.934 & 0.9979 & 0.0026 & 182 & 211 \\
\hline & 75 & 38.376 & 0.9955 & 0.0026 & 142 & 164 \\
\hline & 50 & 44.240 & 1.0046 & 0.0024 & 107 & 124 \\
\hline & 35 & 49.346 & 0.9999 & 0.0022 & 86 & 100 \\
\hline & 25 & 52.334 & 1.0016 & 0.0022 & 76 & 88 \\
\hline & 20 & 52.000 & 1.0036 & 0.0021 & 77 & 89 \\
\hline & 15 & 50.450 & 1.0026 & 0.0017 & 82 & 95 \\
\hline & 10 & 40.680 & 1.0024 & 0.0014 & 126 & 146 \\
\hline \multirow[t]{6}{*}{2.5} & 50 & 43.750 & 1.0018 & 0.0023 & 109 & 126 \\
\hline & 35 & 48.472 & 1.0013 & 0.0022 & 89 & 103 \\
\hline & 25 & 51.794 & 0.9965 & 0.0021 & 78 & 90 \\
\hline & 20 & 51.784 & 1.0005 & 0.0020 & 78 & 90 \\
\hline & 15 & 49.866 & 1.0039 & 0.0019 & 84 & 97 \\
\hline & 10 & 40.274 & 1.0018 & 0.0015 & 129 & 149 \\
\hline
\end{tabular}

a 76 wt \% plutonium-239, 12 wt \% plutonium-240, and 12 wt \% plutonium-241.

${ }^{b}$ The areal density in $\mathrm{kg} / \mathrm{m}^{2}$ can be obtained by multiplying the $\mathrm{g} / \mathrm{ft}^{2}$ values by 0.010763 . 


\section{APPENDIX C}

\section{EXAMPLE INPUT FILES}




\section{APPENDIX C}

\section{EXAMPLE INPUT FILES}

Example input for the first graded approach: Critical pitch search for solution-filled cylinders

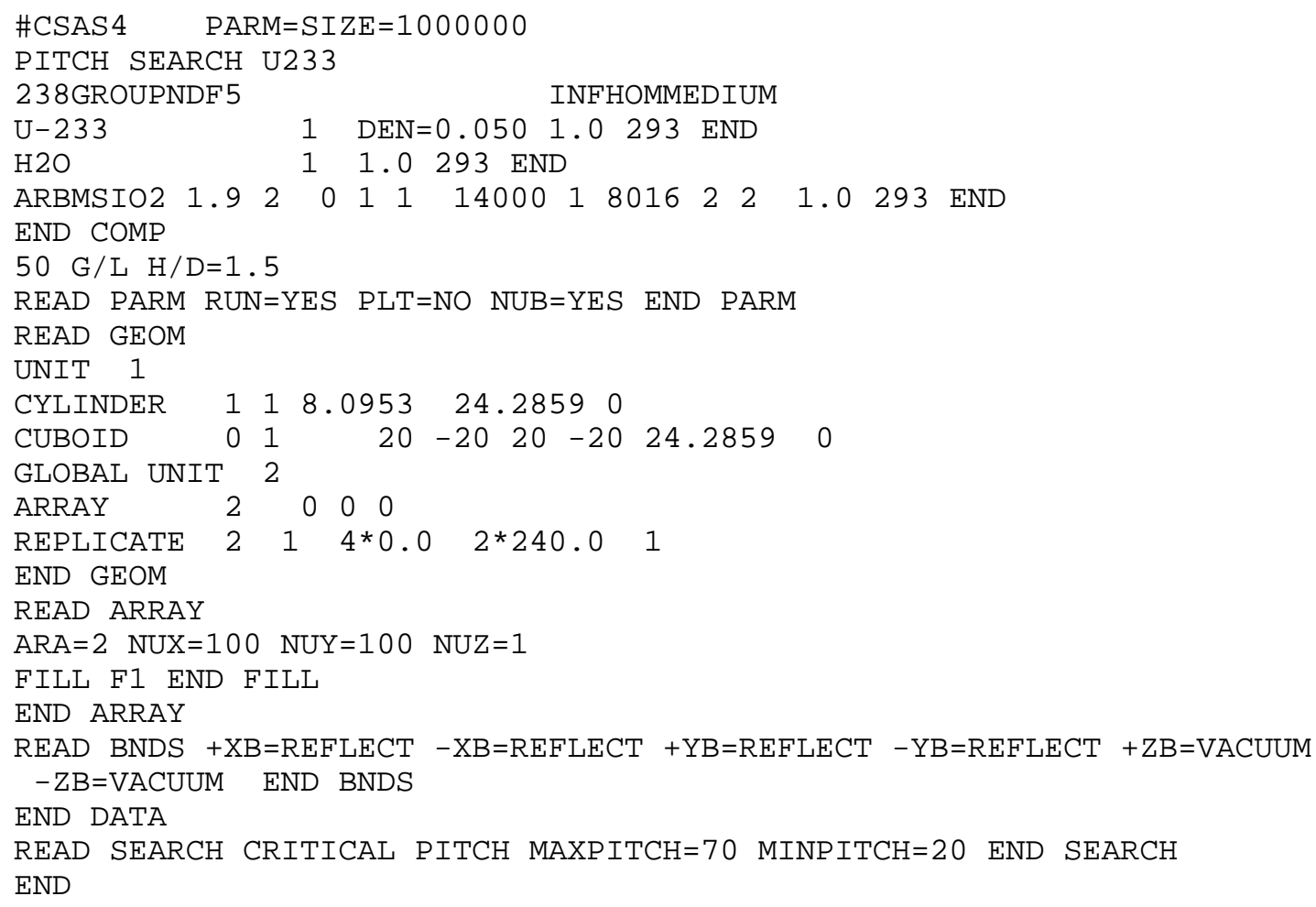


Example input for the second graded approach: Critical slab thickness search

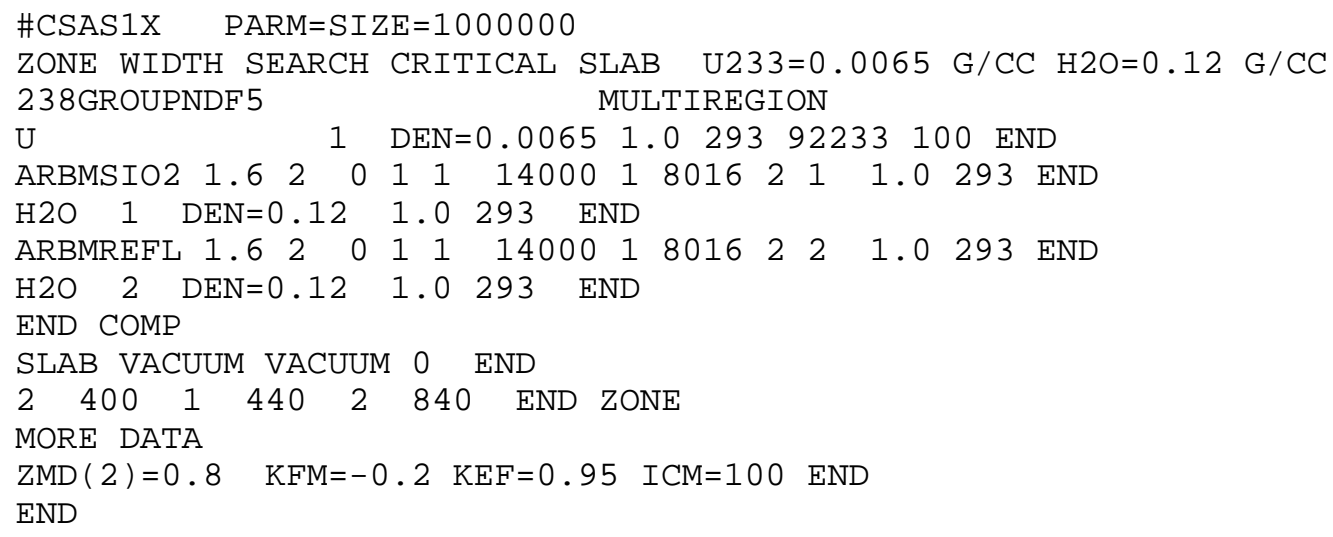

Example input for the third graded approach: Critical concentration search in vaulted system

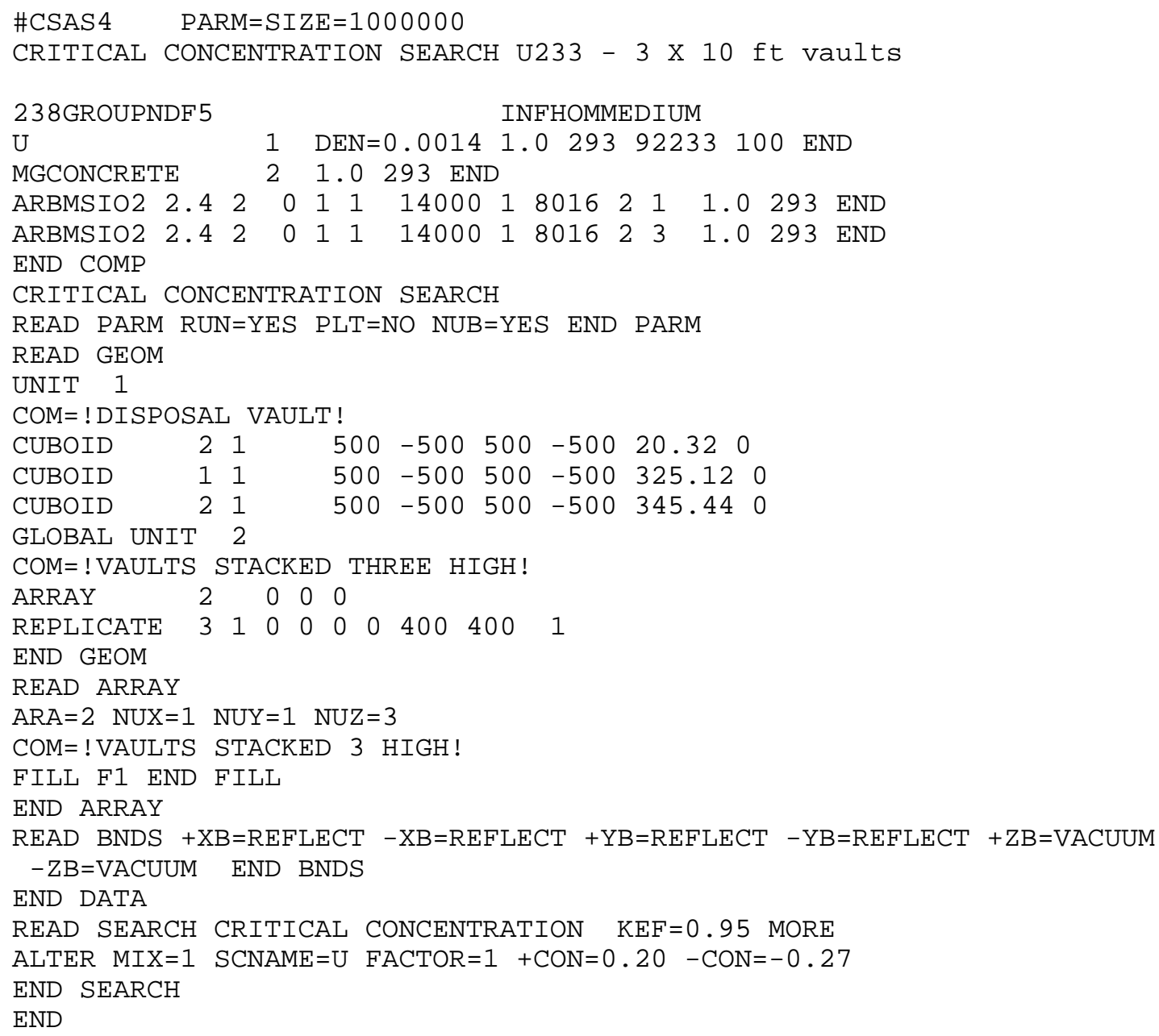


APPENDIX D

\section{DATA FOR SECOND AND THIRD GRADED-APPROACH METHODS}


Table D.1 Uranium-233 systems

\begin{tabular}{|c|c|c|c|c|c|c|c|c|}
\hline \multirow[b]{2}{*}{$\mathrm{g}^{233} \mathrm{U} / \mathrm{cm}^{3}$} & \multirow[b]{2}{*}{$\begin{array}{l}\mathrm{g}^{233} \mathrm{U} \\
/ \mathrm{g} \mathrm{SiO} 2\end{array}$} & \multirow[b]{2}{*}{$\mathrm{g} \mathrm{H}_{2} \mathrm{O} / \mathrm{cm}^{3}$} & \multirow[b]{2}{*}{$\begin{array}{l}\mathrm{g} \mathrm{H}_{2} \mathrm{O} \\
/ \mathrm{g} \mathrm{SiO}_{2}\end{array}$} & \multirow[b]{2}{*}{$k_{i n f}$} & \multicolumn{2}{|c|}{ Critical slab } & \multicolumn{2}{|c|}{ Critical sphere } \\
\hline & & & & & $\begin{array}{l}\text { Thickness } \\
(\mathrm{cm})\end{array}$ & $\begin{array}{c}\text { Areal } \\
\text { density } \\
\left(\mathrm{kg}^{233} \mathrm{U} /\right. \\
\left.\mathrm{m}^{2}\right)\end{array}$ & $\begin{array}{c}\text { Radius } \\
(\mathrm{cm})\end{array}$ & $\mathrm{kg}^{233} \mathrm{U}$ \\
\hline 0.00110 & 0.00069 & 0.00 & 0.00 & 0.987 & 1473.70 & 16.211 & 773.06 & 2128.73 \\
\hline 0.00125 & 0.00000 & 0.00 & 5.44 & 1.033 & 435.23 & 5.440 & 423.52 & 397.76 \\
\hline 0.00150 & 0.00094 & 0.00 & 0.00 & 1.140 & 258.73 & 3.881 & 307.94 & 183.48 \\
\hline 0.00165 & 0.00103 & 0.00 & 0.00 & 1.196 & 216.43 & 3.571 & 266.10 & 130.23 \\
\hline 0.00165 & 0.00103 & 0.03 & 0.02 & 1.006 & 332.07 & 5.479 & 387.93 & 403.49 \\
\hline 0.00180 & 0.00113 & 0.00 & 0.00 & 1.247 & 189.24 & 3.406 & 238.75 & 102.61 \\
\hline 0.00180 & 0.00113 & 0.03 & 0.02 & 1.056 & 231.96 & 4.175 & 274.32 & 155.64 \\
\hline 0.00200 & 0.00125 & 0.00 & 0.00 & 1.307 & 163.91 & 3.278 & 213.88 & 81.97 \\
\hline 0.00200 & 0.00125 & 0.03 & 0.02 & 1.116 & 174.88 & 3.498 & 213.02 & 80.98 \\
\hline 0.00200 & 0.00125 & 0.06 & 0.04 & 1.000 & 284.35 & 5.687 & 323.58 & 283.83 \\
\hline 0.00220 & 0.00138 & 0.00 & 0.00 & 1.361 & 148.00 & 3.256 & 196.43 & 69.84 \\
\hline 0.00220 & 0.00138 & 0.03 & 0.02 & 1.171 & 153.37 & 3.374 & 181.06 & 54.70 \\
\hline 0.00220 & 0.00138 & 0.06 & 0.04 & 1.054 & 186.46 & 4.102 & 217.98 & 95.45 \\
\hline 0.00220 & 0.00138 & 0.09 & 0.06 & 0.962 & 496.86 & 10.931 & 596.17 & 1952.64 \\
\hline 0.00250 & 0.00156 & 0.00 & 0.00 & 1.432 & 125.45 & 3.136 & 178.00 & 59.06 \\
\hline 0.00250 & 0.00156 & 0.03 & 0.02 & 1.244 & 121.14 & 3.029 & 153.19 & 37.65 \\
\hline 0.00250 & 0.00156 & 0.06 & 0.04 & 1.127 & 132.88 & 3.322 & 161.95 & 44.48 \\
\hline 0.00250 & 0.00156 & 0.09 & 0.06 & 1.034 & 179.38 & 4.485 & 206.74 & 92.53 \\
\hline 0.00250 & 0.00156 & 0.12 & 0.08 & 0.956 & 596.09 & 14.902 & 777.74 & 4926.43 \\
\hline 0.00280 & 0.00175 & 0.00 & 0.00 & 1.492 & 108.90 & 3.049 & 164.97 & 52.66 \\
\hline 0.00280 & 0.00175 & 0.03 & 0.02 & 1.307 & 103.70 & 2.904 & 136.11 & 29.57 \\
\hline 0.00280 & 0.00175 & 0.06 & 0.04 & 1.192 & 107.22 & 3.002 & 135.38 & 29.10 \\
\hline 0.00280 & 0.00175 & 0.09 & 0.06 & 1.099 & 125.97 & 3.527 & 150.56 & 40.03 \\
\hline 0.00280 & 0.00175 & 0.12 & 0.08 & 1.020 & 175.23 & 4.906 & 198.76 & 92.09 \\
\hline 0.00280 & 0.00175 & 0.15 & 0.09 & 0.952 & 863.78 & 24.186 & 147.66 & 37.76 \\
\hline
\end{tabular}


Table D.1 (continued)

\begin{tabular}{|c|c|c|c|c|c|c|c|c|}
\hline \multirow[b]{2}{*}{$\mathrm{g}^{233} \mathrm{U} / \mathrm{cm}^{3}$} & \multirow[b]{2}{*}{$\begin{array}{l}\mathrm{g}^{233} \mathrm{U} \\
/ \mathrm{g} \mathrm{SiO}\end{array}$} & \multirow[b]{2}{*}{$\mathrm{g} \mathrm{H}_{2} \mathrm{O} / \mathrm{cm}^{3}$} & \multirow[b]{2}{*}{$\begin{array}{l}\mathrm{g} \mathrm{H}_{2} \mathrm{O} \\
/ \mathrm{g} \mathrm{SiO}_{2}\end{array}$} & \multirow[b]{2}{*}{$k_{i n f}$} & \multicolumn{2}{|c|}{ Critical slab } & \multicolumn{2}{|c|}{ Critical sphere } \\
\hline & & & & & $\begin{array}{l}\text { Thickness } \\
\text { (cm) }\end{array}$ & $\begin{array}{c}\text { Areal } \\
\text { density } \\
\left(\mathrm{kg}^{233} \mathrm{U}\right. \\
\left./ \mathrm{m}^{2}\right)\end{array}$ & $\begin{array}{c}\text { Radius } \\
(\mathrm{cm})\end{array}$ & $\mathrm{kg}{ }^{233} \mathrm{U}$ \\
\hline 0.00320 & 0.00200 & 0.00 & 0.00 & 1.559 & 96.46 & 3.087 & 152.40 & 47.45 \\
\hline 0.00320 & 0.00200 & 0.03 & 0.02 & 1.381 & 89.26 & 2.856 & 121.19 & 23.86 \\
\hline 0.00320 & 0.00200 & 0.06 & 0.04 & 1.268 & 91.52 & 2.929 & 115.21 & 20.50 \\
\hline 0.00320 & 0.00200 & 0.09 & 0.06 & 1.175 & 95.87 & 3.068 & 118.81 & 22.48 \\
\hline 0.00320 & 0.00200 & 0.12 & 0.08 & 1.096 & 111.19 & 3.558 & 132.52 & 31.19 \\
\hline 0.00320 & 0.00200 & 0.15 & 0.09 & 1.027 & 147.31 & 4.714 & 167.80 & 63.33 \\
\hline 0.00320 & 0.00200 & 0.18 & 0.11 & 0.966 & 184.58 & 5.907 & 350.73 & 578.31 \\
\hline 0.00360 & 0.00225 & 0.00 & 0.00 & 1.615 & 87.90 & 3.164 & 143.21 & 44.29 \\
\hline 0.00360 & 0.00225 & 0.03 & 0.02 & 1.444 & 76.64 & 2.759 & 111.05 & 20.65 \\
\hline 0.00360 & 0.00225 & 0.06 & 0.04 & 1.333 & 75.81 & 2.729 & 102.73 & 16.35 \\
\hline 0.00360 & 0.00225 & 0.09 & 0.06 & 1.242 & 79.10 & 2.848 & 101.93 & 15.97 \\
\hline 0.00360 & 0.00225 & 0.12 & 0.08 & 1.163 & 86.56 & 3.116 & 106.71 & 18.32 \\
\hline 0.00360 & 0.00225 & 0.15 & 0.09 & 1.094 & 100.46 & 3.617 & 118.65 & 25.19 \\
\hline 0.00360 & 0.00225 & 0.18 & 0.11 & 1.033 & 127.50 & 4.590 & 145.65 & 46.59 \\
\hline 0.00360 & 0.00225 & 0.21 & 0.13 & 0.978 & 215.93 & 7.773 & 238.76 & 205.25 \\
\hline 0.00450 & 0.00281 & 0.00 & 0.00 & 1.710 & 73.12 & 3.290 & 129.18 & 40.63 \\
\hline 0.00450 & 0.00281 & 0.03 & 0.02 & 1.557 & 64.25 & 2.891 & 96.69 & 17.04 \\
\hline 0.00450 & 0.00281 & 0.06 & 0.04 & 1.454 & 61.454 & 2.765 & 86.39 & 12.15 \\
\hline 0.00450 & 0.00281 & 0.09 & 0.06 & 1.366 & 61.716 & 2.777 & 82.10 & 10.43 \\
\hline 0.00450 & 0.00281 & 0.12 & 0.08 & 1.290 & 63.873 & 2.874 & 81.01 & 10.02 \\
\hline 0.00450 & 0.00281 & 0.15 & 0.09 & 1.221 & 64.53 & 2.904 & 82.39 & 10.54 \\
\hline 0.00450 & 0.00281 & 0.18 & 0.11 & 1.160 & 70.14 & 3.156 & 86.39 & 12.15 \\
\hline 0.00450 & 0.00281 & 0.21 & 0.13 & 1.105 & 78.54 & 3.534 & 94.00 & 15.66 \\
\hline 0.00450 & 0.00281 & 0.25 & 0.16 & 1.039 & 100.51 & 4.523 & 115.01 & 28.68 \\
\hline 0.00450 & 0.00281 & 0.29 & 0.18 & 0.980 & 170.86 & 7.689 & 188.21 & 125.67 \\
\hline 0.00550 & 0.00344 & 0.00 & 0.00 & 1.784 & 62.66 & 3.446 & 119.26 & 39.08 \\
\hline 0.00550 & 0.00344 & 0.03 & 0.02 & 1.650 & 52.22 & 2.872 & 87.23 & 15.29 \\
\hline 0.00550 & 0.00344 & 0.06 & 0.04 & 1.555 & 50.744 & 2.791 & 76.34 & 10.25 \\
\hline 0.00550 & 0.00344 & 0.09 & 0.06 & 1.473 & 49.793 & 2.739 & 70.86 & 8.20 \\
\hline 0.00550 & 0.12000 & 0.12 & 2.75 & 1.400 & 50.072 & 2.754 & 67.97 & 7.23 \\
\hline
\end{tabular}


Table D.1 (continued)

\begin{tabular}{|c|c|c|c|c|c|c|c|c|}
\hline \multirow[b]{2}{*}{$\mathrm{g}^{233} \mathrm{U} / \mathrm{cm}^{3}$} & \multirow[b]{2}{*}{$\begin{array}{l}\mathrm{g}^{233} \mathrm{U} \\
/ \mathrm{g} \mathrm{SiO} 2\end{array}$} & \multirow[b]{2}{*}{$\mathrm{g} \mathrm{H}_{2} \mathrm{O} / \mathrm{cm}^{3}$} & \multirow[b]{2}{*}{$\begin{array}{l}\mathrm{g} \mathrm{H}_{2} \mathrm{O} \\
/ \mathrm{g} \mathrm{SiO}_{2}\end{array}$} & \multirow[b]{2}{*}{$k_{i n f}$} & \multicolumn{2}{|c|}{ Critical slab } & \multicolumn{2}{|c|}{ Critical sphere } \\
\hline & & & & & $\begin{array}{l}\text { Thickness } \\
\text { (cm) }\end{array}$ & $\begin{array}{c}\text { Areal } \\
\text { density } \\
\left(\mathrm{kg}^{233} \mathrm{U}\right. \\
\left./ \mathrm{m}^{2}\right)\end{array}$ & $\begin{array}{c}\text { Radius } \\
(\mathrm{cm})\end{array}$ & $\mathrm{kg}{ }^{233} \mathrm{U}$ \\
\hline 0.00550 & 0.00344 & 0.15 & 0.09 & 1.334 & 51.248 & 2.819 & 66.77 & 6.86 \\
\hline 0.00550 & 0.00344 & 0.18 & 0.11 & 1.274 & 53.272 & 2.930 & 66.87 & 6.89 \\
\hline 0.00550 & 0.00344 & 0.21 & 0.13 & 1.219 & 53.44 & 2.939 & 68.23 & 7.32 \\
\hline 0.00550 & 0.00344 & 0.25 & 0.16 & 1.153 & 58.79 & 3.233 & 72.21 & 8.67 \\
\hline 0.00550 & 0.00344 & 0.29 & 0.18 & 1.094 & 67.50 & 3.713 & 79.95 & 11.77 \\
\hline 0.00550 & 0.00344 & 0.32 & 0.20 & 1.053 & 78.18 & 4.300 & 90.18 & 16.90 \\
\hline 0.00550 & 0.00344 & 0.36 & 0.23 & 1.004 & 107.05 & 5.888 & 119.13 & 38.95 \\
\hline 0.00550 & 0.00344 & 0.40 & 0.25 & 0.959 & 272.32 & 14.978 & 305.15 & 654.62 \\
\hline 0.00650 & 0.00406 & 0.00 & 0.00 & 1.836 & 55.39 & 3.600 & 112.38 & 38.64 \\
\hline 0.00650 & 0.00406 & 0.03 & 0.02 & 1.720 & 45.74 & 2.973 & 81.00 & 14.47 \\
\hline 0.00650 & 0.00406 & 0.06 & 0.04 & 1.634 & 43.31 & 2.815 & 69.97 & 9.33 \\
\hline 0.00650 & 0.00406 & 0.09 & 0.06 & 1.557 & 41.82 & 2.718 & 64.05 & 7.15 \\
\hline 0.00650 & 0.00406 & 0.12 & 0.08 & 1.488 & 41.35 & 2.688 & 60.52 & 6.04 \\
\hline 0.00650 & 0.00406 & 0.15 & 0.09 & 1.425 & 41.38 & 2.690 & 58.40 & 5.42 \\
\hline 0.00650 & 0.00406 & 0.18 & 0.11 & 1.367 & 42.05 & 2.733 & 57.27 & 5.11 \\
\hline 0.00650 & 0.00406 & 0.21 & 0.13 & 1.313 & 43.05 & 2.798 & 56.95 & 5.03 \\
\hline 0.00650 & 0.00406 & 0.25 & 0.16 & 1.248 & 44.41 & 2.887 & 57.64 & 5.21 \\
\hline 0.00650 & 0.00406 & 0.29 & 0.18 & 1.189 & 47.55 & 3.091 & 59.66 & 5.78 \\
\hline 0.00650 & 0.00406 & 0.32 & 0.20 & 1.149 & 50.81 & 3.303 & 62.30 & 6.58 \\
\hline 0.00650 & 0.00406 & 0.36 & 0.23 & 1.099 & 57.11 & 3.712 & 67.89 & 8.52 \\
\hline 0.00650 & 0.00406 & 0.40 & 0.25 & 1.053 & 67.29 & 4.374 & 77.62 & 12.73 \\
\hline 0.01000 & 0.00625 & 0.00 & 0.0000 & 1.935 & 40.70 & 40.700 & 98.55 & 40.09 \\
\hline 0.01000 & 0.01 & 0.03 & 0.0188 & 1.867 & 33.42 & 3.342 & 68.11 & 13.23 \\
\hline 0.01000 & 0.00625 & 0.06 & 0.0375 & 1.805 & 30.57 & 3.057 & 57.56 & 7.99 \\
\hline 0.01000 & 0.00625 & 0.09 & 0.0563 & 1.746 & 29.05 & 2.905 & 51.53 & 5.73 \\
\hline 0.01000 & 0.00625 & 0.12 & 0.0750 & 1.690 & 28.13 & 2.813 & 47.53 & 4.50 \\
\hline 0.01000 & 0.00625 & 0.15 & 0.0938 & 1.638 & 27.56 & 2.756 & 44.69 & 3.74 \\
\hline 0.01000 & 0.00625 & 0.18 & 0.1125 & 1.588 & 27.21 & 2.721 & 42.59 & 3.24 \\
\hline 0.01000 & 0.00625 & 0.21 & 0.1313 & 1.542 & 27.04 & 2.704 & 41.02 & 2.89 \\
\hline 0.01000 & 0.00625 & 0.25 & 0.1563 & 1.483 & 27.01 & 2.701 & 39.52 & 2.59 \\
\hline 0.01000 & 0.00625 & 0.29 & 0.1813 & 1.429 & 27.20 & 2.720 & 38.54 & 2.40 \\
\hline
\end{tabular}


Table D.1 (continued)

\begin{tabular}{|c|c|c|c|c|c|c|c|c|}
\hline \multirow[b]{2}{*}{$\mathrm{g}^{233} \mathrm{U} / \mathrm{cm}^{3}$} & \multirow[b]{2}{*}{$\begin{array}{l}\mathrm{g}^{233} \mathrm{U} \\
/ \mathrm{g} \mathrm{SiO}\end{array}$} & \multirow[b]{2}{*}{$\mathrm{g} \mathrm{H}_{2} \mathrm{O} / \mathrm{cm}^{3}$} & \multirow[b]{2}{*}{$\begin{array}{l}\mathrm{g} \mathrm{H}_{2} \mathrm{O} \\
/ \mathrm{g} \mathrm{SiO}_{2}\end{array}$} & \multirow[b]{2}{*}{$k_{i n f}$} & \multicolumn{2}{|c|}{ Critical slab } & \multicolumn{2}{|c|}{ Critical sphere } \\
\hline & & & & & $\begin{array}{l}\text { Thickness } \\
\text { (cm) }\end{array}$ & $\begin{array}{c}\text { Areal } \\
\text { density } \\
\left(\mathrm{kg}^{233} \mathrm{U}\right. \\
\left./ \mathrm{m}^{2}\right)\end{array}$ & $\begin{array}{c}\text { Radius } \\
(\mathrm{cm})\end{array}$ & $\mathrm{kg}{ }^{233} \mathrm{U}$ \\
\hline 0.01000 & 0.00625 & 0.32 & 0.2000 & 1.391 & 27.47 & 2.747 & 38.08 & 2.31 \\
\hline 0.01000 & 0.00625 & 0.36 & 0.2250 & 1.343 & 28.00 & 2.800 & 37.78 & 2.26 \\
\hline 0.01000 & 0.00625 & 0.40 & 0.2500 & 1.298 & 28.73 & 2.873 & 37.82 & 2.27 \\
\hline 0.01600 & 0.01 & 0.00 & 0.0000 & 2.000 & 29.12 & 29.120 & 85.06 & 41.25 \\
\hline 0.01600 & 0.01 & 0.03 & 0.0188 & 1.975 & 24.31 & 3.890 & 59.57 & 14.17 \\
\hline 0.01600 & 0.01 & 0.06 & 0.0375 & 1.940 & 22.22 & 3.555 & 49.68 & 8.22 \\
\hline 0.01600 & 0.01 & 0.09 & 0.0563 & 1.902 & 21.01 & 3.362 & 43.84 & 5.65 \\
\hline 0.01600 & 0.01 & 0.12 & 0.0750 & 1.863 & 20.19 & 3.230 & 39.86 & 4.24 \\
\hline 0.01600 & 0.01 & 0.15 & 0.0938 & 1.825 & 19.60 & 3.136 & 36.92 & 3.37 \\
\hline 0.01600 & 0.01 & 0.18 & 0.1125 & 1.787 & 19.10 & 3.056 & 34.64 & 2.79 \\
\hline 0.01600 & 0.01 & 0.21 & 0.1313 & 1.751 & 18.74 & 2.998 & 32.83 & 2.37 \\
\hline 0.01600 & 0.01 & 0.25 & 0.1563 & 1.704 & 18.37 & 2.939 & 30.93 & 1.98 \\
\hline 0.01600 & 0.01 & 0.29 & 0.1813 & 1.660 & 18.07 & 2.891 & 29.43 & 1.71 \\
\hline 0.01600 & 0.01 & 0.32 & 0.2000 & 1.628 & 17.92 & 2.867 & 28.52 & 1.55 \\
\hline 0.01600 & 0.01 & 0.36 & 0.2250 & 1.587 & 17.78 & 2.845 & 27.52 & 1.40 \\
\hline 0.01600 & 0.01 & 0.40 & 0.2500 & 1.548 & 17.68 & 2.829 & 26.72 & 1.28 \\
\hline 0.02250 & 0.01406 & 0.00 & 0.00 & 2.031 & 22.74 & 22.740 & 78.24 & 45.14 \\
\hline 0.02250 & 0.01406 & 0.03 & 0.02 & 2.025 & 19.40 & 4.365 & 54.95 & 15.64 \\
\hline 0.02250 & 0.01406 & 0.06 & 0.04 & 2.006 & 17.80 & 4.005 & 45.60 & 8.94 \\
\hline 0.02250 & 0.01406 & 0.09 & 0.06 & 1.982 & 16.84 & 3.789 & 39.99 & 6.03 \\
\hline 0.02250 & 0.01406 & 0.12 & 0.08 & 1.955 & 16.16 & 3.636 & 36.11 & 4.44 \\
\hline 0.02250 & 0.01406 & 0.15 & 0.09 & 1.927 & 15.62 & 3.515 & 33.22 & 3.46 \\
\hline 0.02250 & 0.01406 & 0.18 & 0.11 & 1.899 & 15.19 & 3.418 & 30.96 & 2.80 \\
\hline 0.02250 & 0.01406 & 0.21 & 0.13 & 1.871 & 14.84 & 3.339 & 29.14 & 2.33 \\
\hline 0.02250 & 0.01406 & 0.25 & 0.16 & 1.834 & 14.43 & 3.247 & 27.18 & 1.89 \\
\hline 0.02250 & 0.01406 & 0.29 & 0.18 & 1.798 & 14.11 & 3.175 & 25.62 & 1.58 \\
\hline 0.02250 & 0.01406 & 0.32 & 0.20 & 1.772 & 13.91 & 3.130 & 24.64 & 1.41 \\
\hline 0.02250 & 0.01406 & 0.36 & 0.23 & 1.738 & 13.67 & 3.076 & 23.53 & 1.23 \\
\hline 0.02250 & 0.02250 & 0.40 & 0.40 & 1.705 & 13.48 & 3.033 & 22.93 & 1.14 \\
\hline 0.08 & 0.05000 & 0.00 & 0.00 & 2.130 & 8.54 & 8.540 & 57.55 & 63.87 \\
\hline
\end{tabular}


Table D.1 (continued)

\begin{tabular}{|c|c|c|c|c|c|c|c|c|}
\hline \multirow[b]{2}{*}{$\mathrm{g}^{233} \mathrm{U} / \mathrm{cm}^{3}$} & \multirow[b]{2}{*}{$\begin{array}{l}\mathrm{g}^{233} \mathrm{U} \\
/ \mathrm{g} \mathrm{SiO}\end{array}$} & \multirow[b]{2}{*}{$\mathrm{g} \mathrm{H}_{2} \mathrm{O} / \mathrm{cm}^{3}$} & \multirow[b]{2}{*}{$\begin{array}{l}\mathrm{g} \mathrm{H}_{2} \mathrm{O} \\
/ \mathrm{g} \mathrm{SiO}_{2}\end{array}$} & \multirow[b]{2}{*}{$k_{i n f}$} & \multicolumn{2}{|c|}{ Critical slab } & \multicolumn{2}{|c|}{ Critical sphere } \\
\hline & & & & & $\begin{array}{l}\text { Thickness } \\
(\mathrm{cm})\end{array}$ & $\begin{array}{c}\text { Areal } \\
\text { density } \\
\left(\mathrm{kg}{ }^{233} \mathrm{U}\right. \\
\left./ \mathrm{m}^{2}\right)\end{array}$ & $\begin{array}{c}\text { Radius } \\
(\mathrm{cm})\end{array}$ & $\mathrm{kg}{ }^{233} \mathrm{U}$ \\
\hline 0.08 & 0.05000 & 0.03 & 0.02 & 2.108 & 8.20 & 6.560 & 42.96 & 26.57 \\
\hline 0.08 & 0.05000 & 0.06 & 0.04 & 2.108 & 7.89 & 6.312 & 35.87 & 15.47 \\
\hline 0.08 & 0.05000 & 0.09 & 0.06 & 2.110 & 7.69 & 6.152 & 31.36 & 10.33 \\
\hline 0.08 & 0.05000 & 0.12 & 0.08 & 2.109 & 7.53 & 6.024 & 28.11 & 7.44 \\
\hline 0.08 & 0.05000 & 0.15 & 0.09 & 2.107 & 7.37 & 5.896 & 25.62 & 5.64 \\
\hline 0.08 & 0.05000 & 0.18 & 0.11 & 2.104 & 7.22 & 5.776 & 23.63 & 4.42 \\
\hline 0.08 & 0.05000 & 0.21 & 0.13 & 2.100 & 7.07 & 5.656 & 21.99 & 3.56 \\
\hline 0.08 & 0.05000 & 0.25 & 0.16 & 2.092 & 6.88 & 5.504 & 20.19 & 2.76 \\
\hline 0.08 & 0.05000 & 0.29 & 0.18 & 2.083 & 6.70 & 5.360 & 18.73 & 2.20 \\
\hline 0.08 & 0.05000 & 0.32 & 0.20 & 2.077 & 6.57 & 5.256 & 17.79 & 1.89 \\
\hline 0.08 & 0.05000 & 0.36 & 0.23 & 2.067 & 6.40 & 5.120 & 16.70 & 1.56 \\
\hline 0.08 & 0.05000 & 0.396 & 0.25 & 2.058 & 6.27 & 5.016 & 15.85 & 1.33 \\
\hline 0.25 & 0.15625 & 0.00 & 0.00 & 2.191 & 3.20 & 3.200 & 41.75 & 76.21 \\
\hline 0.25 & 0.15625 & 0.03 & 0.02 & 2.174 & 3.42 & 8.550 & 34.06 & 41.38 \\
\hline 0.25 & 0.15625 & 0.06 & 0.04 & 2.161 & 3.52 & 8.800 & 29.36 & 26.50 \\
\hline 0.25 & 0.15625 & 0.09 & 0.06 & 2.154 & 3.62 & 9.050 & 26.08 & 18.58 \\
\hline 0.25 & 0.15625 & 0.12 & 0.08 & 2.150 & 3.69 & 9.225 & 23.60 & 13.76 \\
\hline 0.25 & 0.15625 & 0.15 & 0.09 & 2.148 & 3.72 & 9.300 & 21.63 & 10.60 \\
\hline 0.25 & 0.15625 & 0.18 & 0.11 & 2.147 & 3.74 & 9.350 & 20.00 & 8.38 \\
\hline 0.25 & 0.15625 & 0.21 & 0.13 & 2.147 & 3.74 & 9.350 & 18.65 & 6.79 \\
\hline 0.25 & 0.15625 & 0.25 & 0.16 & 2.146 & 3.73 & 9.325 & 17.13 & 5.26 \\
\hline 0.25 & 0.15625 & 0.29 & 0.18 & 2.146 & 3.69 & 9.225 & 15.87 & 4.19 \\
\hline 0.25 & 0.15625 & 0.32 & 0.20 & 2.145 & 3.65 & 9.125 & 15.05 & 3.57 \\
\hline 0.25 & 0.15625 & 0.36 & 0.23 & 2.145 & 3.60 & 9.000 & 14.10 & 2.94 \\
\hline 0.25 & 0.15625 & 0.385 & 0.24 & 2.144 & 3.56 & 8.900 & 13.57 & 2.62 \\
\hline 1 & 0.62500 & 0.00 & 0.00 & 2.301 & 0.87 & 0.870 & 25.01 & 65.53 \\
\hline 1 & 0.62500 & 0.03 & 0.02 & 2.279 & 1.01 & 10.060 & 22.66 & 48.74 \\
\hline 1 & 0.62500 & 0.06 & 0.04 & 2.263 & 1.10 & 11.030 & 20.64 & 36.83 \\
\hline 1 & 0.62500 & 0.09 & 0.06 & 2.250 & 1.20 & 12.000 & 19.00 & 28.73 \\
\hline 1 & 0.62500 & 0.12 & 0.08 & 2.239 & 1.29 & 12.900 & 17.63 & 22.95 \\
\hline 1 & 0.62500 & 0.15 & 0.09 & 2.230 & 1.37 & 13.710 & 16.48 & 18.75 \\
\hline
\end{tabular}


Table D.1 (continued)

\begin{tabular}{|c|c|c|c|c|c|c|c|c|}
\hline \multirow[b]{2}{*}{$\mathrm{g}^{233} \mathrm{U} / \mathrm{cm}^{3}$} & \multirow[b]{2}{*}{$\begin{array}{l}\mathrm{g}^{233} \mathrm{U} \\
/ \mathrm{g} \mathrm{SiO}\end{array}$} & \multirow[b]{2}{*}{$\mathrm{g} \mathrm{H}_{2} \mathrm{O} / \mathrm{cm}^{3}$} & \multirow[b]{2}{*}{$\begin{array}{l}\mathrm{g} \mathrm{H}_{2} \mathrm{O} \\
/ \mathrm{g} \mathrm{SiO}_{2}\end{array}$} & \multirow[b]{2}{*}{$k_{i n f}$} & \multicolumn{2}{|c|}{ Critical slab } & \multicolumn{2}{|c|}{ Critical sphere } \\
\hline & & & & & $\begin{array}{l}\text { Thickness } \\
(\mathrm{cm})\end{array}$ & $\begin{array}{c}\text { Areal } \\
\text { density } \\
\left(\mathrm{kg}^{233} \mathrm{U}\right. \\
\left./ \mathrm{m}^{2}\right)\end{array}$ & $\begin{array}{c}\text { Radius } \\
(\mathrm{cm})\end{array}$ & $\mathrm{kg}{ }^{233} \mathrm{U}$ \\
\hline 1 & 0.62500 & 0.18 & 0.11 & 2.223 & 1.44 & 14.410 & 15.48 & 15.54 \\
\hline 1 & 0.62500 & 0.21 & 0.13 & 2.216 & 1.50 & 14.990 & 14.61 & 13.06 \\
\hline 1 & 0.62500 & 0.25 & 0.16 & 2.209 & 1.56 & 15.610 & 13.61 & 10.56 \\
\hline 1 & 0.62500 & 0.29 & 0.18 & 2.203 & 1.61 & 16.070 & 12.74 & 8.66 \\
\hline 1 & 0.62500 & 0.32 & 0.20 & 2.199 & 1.63 & 16.330 & 12.16 & 7.53 \\
\hline 1 & 0.62500 & 0.35 & 0.22 & 2.196 & 1.65 & 16.520 & 11.64 & 6.61 \\
\hline
\end{tabular}


Table D.2 Plutonium-239 systems

\begin{tabular}{|c|c|c|c|c|c|c|c|c|}
\hline \multirow[b]{2}{*}{$\mathrm{g}^{239} \mathrm{Pu} / \mathrm{cm}^{3}$} & \multirow[b]{2}{*}{$\begin{array}{l}\mathrm{g}^{239} \mathrm{Pu} / \\
\mathrm{g} \mathrm{SiO}_{2}\end{array}$} & \multirow[b]{2}{*}{$\mathrm{g} \mathrm{H}_{2} \mathrm{O} / \mathrm{cm}^{3}$} & \multirow[b]{2}{*}{$\begin{array}{l}\mathrm{g} \mathrm{H}_{2} \mathrm{O} \\
/ \mathrm{g} \mathrm{SiO}_{2}\end{array}$} & \multirow[b]{2}{*}{$k_{i n f}$} & \multicolumn{2}{|c|}{ Critical slab } & \multicolumn{2}{|c|}{ Critical sphere } \\
\hline & & & & & $\begin{array}{l}\text { Thickness } \\
(\mathrm{cm})\end{array}$ & $\begin{array}{c}\text { Areal } \\
\text { density } \\
(\mathrm{kg} \\
\left.{ }^{239} \mathrm{Pu} / \mathrm{m}^{2}\right)\end{array}$ & $\begin{array}{c}\text { Radius } \\
(\mathrm{cm})\end{array}$ & $\operatorname{kg}{ }^{239} \mathrm{Pu}$ \\
\hline 0.00064 & 0.00040 & 0.00 & 0.00 & 0.951 & 8476.25 & 54.248 & 1447.81 & 8135.86 \\
\hline 0.00065 & 0.00040 & 0.00 & 0.00 & 0.954 & 2356.15 & 15.197 & 1237.47 & 5119.79 \\
\hline 0.00065 & 0.00041 & 0.00 & 0.00 & 0.958 & 1628.93 & 10.588 & 1098.92 & 3613.27 \\
\hline 0.00068 & 0.00042 & 0.00 & 0.00 & 0.977 & 831.79 & 5.615 & 766.60 & 1273.80 \\
\hline 0.00070 & 0.00044 & 0.00 & 0.00 & 0.995 & 602.33 & 4.216 & 623.59 & 711.01 \\
\hline 0.00075 & 0.00047 & 0.00 & 0.00 & 1.028 & 447.06 & 3.353 & 498.57 & 389.34 \\
\hline 0.00090 & 0.00056 & 0.00 & 0.00 & 1.115 & 279.39 & 2.515 & 332.20 & 138.21 \\
\hline 0.00100 & 0.00063 & 0.00 & 0.00 & 1.163 & 234.39 & 2.344 & 289.20 & 101.32 \\
\hline 0.00100 & 0.00063 & 0.03 & 0.02 & 0.998 & 338.91 & 3.389 & 371.82 & 215.32 \\
\hline 0.00110 & 0.00069 & 0.00 & 0.00 & 1.205 & 205.56 & 2.261 & 261.55 & 82.44 \\
\hline 0.00110 & 0.00069 & 0.03 & 0.02 & 1.046 & 235.60 & 2.592 & 268.97 & 89.66 \\
\hline 0.00125 & 0.00078 & 0.00 & 0.00 & 1.258 & 186.89 & 2.336 & 234.37 & 67.41 \\
\hline 0.00125 & 0.00078 & 0.03 & 0.02 & 1.110 & 180.32 & 2.254 & 207.15 & 46.54 \\
\hline 0.00125 & 0.00078 & 0.06 & 0.04 & 1.004 & 255.54 & 3.194 & 281.54 & 116.84 \\
\hline 0.00150 & 0.00094 & 0.00 & 0.00 & 1.326 & 151.71 & 2.276 & 206.94 & 55.68 \\
\hline 0.00150 & 0.00094 & 0.03 & 0.02 & 1.197 & 132.31 & 1.985 & 162.56 & 26.99 \\
\hline 0.00150 & 0.00094 & 0.06 & 0.04 & 1.096 & 145.22 & 2.178 & 171.48 & 31.68 \\
\hline 0.00150 & 0.00094 & 0.09 & 0.06 & 1.011 & 202.57 & 3.039 & 224.47 & 71.07 \\
\hline 0.00165 & 0.00103 & 0.00 & 0.00 & 1.359 & 140.40 & 2.317 & 196.10 & 52.12 \\
\hline 0.00165 & 0.00103 & 0.03 & 0.02 & 1.241 & 116.75 & 1.926 & 147.73 & 22.28 \\
\hline 0.00165 & 0.00103 & 0.06 & 0.04 & 1.143 & 120.74 & 1.992 & 147.21 & 22.05 \\
\hline 0.00165 & 0.00103 & 0.09 & 0.06 & 1.060 & 145.95 & 2.408 & 168.03 & 32.79 \\
\hline 0.00165 & 0.00103 & 0.12 & 0.08 & 0.988 & 226.02 & 3.729 & 245.46 & 102.21 \\
\hline
\end{tabular}


Table D.2 (continued)

\begin{tabular}{|c|c|c|c|c|c|c|c|c|}
\hline \multirow[b]{2}{*}{$\mathrm{g}^{239} \mathrm{Pu} / \mathrm{cm}^{3}$} & \multirow[b]{2}{*}{$\begin{array}{l}\mathrm{g}^{239} \mathrm{Pu} \\
/ \mathrm{g} \mathrm{SiO}{ }_{2}\end{array}$} & \multirow[b]{2}{*}{$\mathrm{g} \mathrm{H}_{2} \mathrm{O} / \mathrm{cm}^{3}$} & \multirow[b]{2}{*}{$\begin{array}{l}\mathrm{g} \mathrm{H}_{2} \mathrm{O} \\
/ \mathrm{g} \mathrm{SiO}_{2}\end{array}$} & \multirow[b]{2}{*}{$k_{i n f}$} & \multicolumn{2}{|c|}{ Critical slab } & \multicolumn{2}{|c|}{ Critical sphere } \\
\hline & & & & & $\begin{array}{l}\text { Thickness } \\
(\mathrm{cm})\end{array}$ & $\begin{array}{c}\text { Areal } \\
\text { density } \\
(\mathrm{kg} \\
\left.{ }^{239} \mathrm{Pu} / \mathrm{m}^{2}\right)\end{array}$ & $\begin{array}{c}\text { Radius } \\
(\mathrm{cm})\end{array}$ & $\mathrm{kg}^{239} \mathrm{Pu}$ \\
\hline 0.0018 & 0.00113 & 0.00 & 0.00 & 1.386 & 131.88 & 2.374 & 187.64 & 49.81 \\
\hline 0.0018 & 0.00113 & 0.03 & 0.02 & 1.280 & 105.31 & 1.896 & 137.09 & 19.43 \\
\hline 0.0018 & 0.00113 & 0.06 & 0.04 & 1.185 & 105.36 & 1.896 & 131.63 & 17.20 \\
\hline 0.0018 & 0.00113 & 0.09 & 0.06 & 1.104 & 118.75 & 2.138 & 140.61 & 20.96 \\
\hline 0.0018 & 0.00113 & 0.12 & 0.08 & 1.032 & 151.06 & 2.719 & 169.83 & 36.93 \\
\hline 0.0018 & 0.00113 & 0.15 & 0.09 & 0.970 & 272.23 & 4.900 & 290.56 & 184.96 \\
\hline 0.0020 & 0.00125 & 0.00 & 0.00 & 1.417 & 122.52 & 2.450 & 178.85 & 47.93 \\
\hline 0.0020 & 0.00125 & 0.03 & 0.03 & 1.325 & 92.60 & 1.852 & 126.63 & 17.01 \\
\hline 0.0020 & 0.00125 & 0.06 & 0.04 & 1.235 & 91.23 & 1.825 & 117.73 & 13.67 \\
\hline 0.0020 & 0.00125 & 0.09 & 0.06 & 1.156 & 97.52 & 1.950 & 119.56 & 14.32 \\
\hline 0.0020 & 0.00125 & 0.12 & 0.08 & 1.086 & 111.97 & 2.239 & 131.08 & 18.87 \\
\hline 0.0020 & 0.00125 & 0.15 & 0.09 & 1.023 & 153.62 & 3.072 & 169.74 & 40.97 \\
\hline 0.0020 & 0.00125 & 0.18 & 0.11 & 0.968 & 258.17 & 5.163 & 273.31 & 171.04 \\
\hline 0.0022 & 0.00138 & 0.00 & 0.00 & 1.441 & 115.16 & 2.534 & 172.05 & 46.93 \\
\hline 0.0022 & 0.00138 & 0.03 & 0.03 & 1.364 & 84.65 & 1.862 & 118.93 & 15.50 \\
\hline 0.0022 & 0.00138 & 0.06 & 0.04 & 1.279 & 81.36 & 1.790 & 108.04 & 11.62 \\
\hline 0.0022 & 0.00138 & 0.09 & 0.06 & 1.202 & 84.23 & 1.853 & 106.50 & 11.13 \\
\hline 0.0022 & 0.00138 & 0.12 & 0.08 & 1.134 & 91.89 & 2.022 & 111.15 & 12.65 \\
\hline 0.0022 & 0.00138 & 0.15 & 0.09 & 1.072 & 106.58 & 2.345 & 123.56 & 17.39 \\
\hline 0.0022 & 0.00138 & 0.18 & 0.11 & 1.017 & 137.08 & 3.016 & 152.70 & 32.81 \\
\hline 0.0022 & 0.00138 & 0.21 & 0.13 & 0.967 & 242.88 & 5.343 & 258.29 & 158.78 \\
\hline 0.0025 & 0.00250 & 0.00 & 0.00 & 1.471 & 106.51 & 2.663 & 164.21 & 46.37 \\
\hline 0.0025 & 0.00156 & 0.03 & 0.03 & 1.412 & 75.81 & 1.895 & 110.47 & 14.12 \\
\hline 0.0025 & 0.00156 & 0.06 & 0.04 & 1.335 & 71.11 & 1.778 & 97.99 & 9.85 \\
\hline 0.0025 & 0.00156 & 0.09 & 0.06 & 1.263 & 71.42 & 1.785 & 93.81 & 8.64 \\
\hline 0.0025 & 0.00156 & 0.12 & 0.08 & 1.196 & 74.68 & 1.867 & 94.04 & 8.71 \\
\hline 0.0025 & 0.00156 & 0.15 & 0.09 & 1.136 & 81.01 & 2.025 & 98.14 & 9.90 \\
\hline 0.0025 & 0.00156 & 0.18 & 0.11 & 1.082 & 91.82 & 2.296 & 107.27 & 12.93 \\
\hline 0.0025 & 0.00156 & 0.21 & 0.13 & 1.032 & 111.67 & 2.792 & 125.84 & 20.87 \\
\hline 0.0025 & 0.00156 & 0.25 & 0.16 & 0.972 & 195.18 & 4.880 & 207.60 & 93.70 \\
\hline 0.0028 & 0.00175 & 0.00 & 0.00 & 1.493 & 99.96 & 2.799 & 158.23 & 46.47 \\
\hline 0.0028 & 0.00175 & 0.03 & 0.02 & 1.452 & 69.38 & 1.943 & 104.32 & 13.31 \\
\hline
\end{tabular}


Table D.2 (continued)

\begin{tabular}{|c|c|c|c|c|c|c|c|c|}
\hline \multirow[b]{2}{*}{$\mathrm{g}^{239} \mathrm{Pu} / \mathrm{cm}^{3}$} & \multirow[b]{2}{*}{$\begin{array}{l}\mathrm{g}^{239} \mathrm{Pu} \\
/ \mathrm{g} \mathrm{SiO}_{2}\end{array}$} & \multirow[b]{2}{*}{$\mathrm{g} \mathrm{H}_{2} \mathrm{O} / \mathrm{cm}^{3}$} & \multirow[b]{2}{*}{$\begin{array}{l}\mathrm{g} \mathrm{H}_{2} \mathrm{O} \\
/ \mathrm{g} \mathrm{SiO}_{2}\end{array}$} & \multirow[b]{2}{*}{$k_{\text {inf }}$} & \multicolumn{2}{|c|}{ Critical slab } & \multicolumn{2}{|c|}{ Critical sphere } \\
\hline & & & & & $\begin{array}{l}\text { Thickness } \\
(\mathrm{cm})\end{array}$ & $\begin{array}{c}\text { Areal } \\
\text { density } \\
(\mathrm{kg} \\
\left.{ }^{239} \mathrm{Pu} / \mathrm{m}^{2}\right)\end{array}$ & $\begin{array}{l}\text { Radius } \\
(\mathrm{cm})\end{array}$ & $\mathrm{kg}^{239} \mathrm{Pu}$ \\
\hline 0.0028 & 0.00175 & 0.06 & 0.04 & 1.382 & 64.86 & 1.816 & 90.98 & 8.83 \\
\hline 0.0028 & 0.00175 & 0.09 & 0.06 & 1.314 & 64.04 & 1.793 & 85.45 & 7.32 \\
\hline 0.0028 & 0.00175 & 0.12 & 0.08 & 1.251 & 66.20 & 1.854 & 83.67 & 6.87 \\
\hline 0.0028 & 0.00175 & 0.15 & 0.09 & 1.192 & 68.11 & 1.907 & 84.55 & 7.09 \\
\hline 0.0028 & 0.00175 & 0.18 & 0.11 & 1.139 & 73.21 & 2.050 & 88.08 & 8.01 \\
\hline 0.0028 & 0.00175 & 0.21 & 0.13 & 1.090 & 81.74 & 2.289 & 95.07 & 10.08 \\
\hline 0.0028 & 0.00175 & 0.25 & 0.16 & 1.030 & 102.57 & 2.872 & 114.40 & 17.56 \\
\hline 0.0028 & 0.00175 & 0.29 & 0.18 & 0.977 & 163.68 & 4.583 & 175.17 & 63.04 \\
\hline 0.0032 & 0.00200 & 0.00 & 0.00 & 1.516 & 93.14 & 2.980 & 152.19 & 47.25 \\
\hline 0.0032 & 0.00200 & 0.03 & 0.02 & 1.494 & 62.97 & 2.015 & 98.29 & 12.73 \\
\hline 0.0032 & 0.00200 & 0.06 & 0.04 & 1.434 & 57.79 & 1.849 & 84.31 & 8.03 \\
\hline 0.0032 & 0.00200 & 0.09 & 0.06 & 1.371 & 56.04 & 1.793 & 77.83 & 6.32 \\
\hline 0.0032 & 0.00200 & 0.12 & 0.08 & 1.312 & 56.11 & 1.796 & 74.70 & 5.59 \\
\hline 0.0032 & 0.00200 & 0.15 & 0.09 & 1.256 & 57.46 & 1.839 & 73.64 & 5.35 \\
\hline 0.0032 & 0.00200 & 0.18 & 0.11 & 1.205 & 58.66 & 1.877 & 74.23 & 5.48 \\
\hline 0.0032 & 0.00200 & 0.21 & 0.13 & 1.157 & 62.30 & 1.994 & 76.52 & 6.00 \\
\hline 0.0032 & 0.00200 & 0.25 & 0.16 & 1.098 & 70.05 & 2.242 & 82.81 & 7.61 \\
\hline 0.0032 & 0.00200 & 0.29 & 0.18 & 1.045 & 83.86 & 2.684 & 95.47 & 11.66 \\
\hline 0.0032 & 0.00200 & 0.32 & 0.20 & 1.008 & 103.62 & 3.316 & 114.43 & 20.09 \\
\hline 0.0032 & 0.00200 & 0.36 & 0.23 & 0.963 & 189.77 & 6.073 & 201.31 & 109.35 \\
\hline 0.0036 & 0.00225 & 0.00 & 0.00 & 1.532 & 87.85 & 3.163 & 147.50 & 48.40 \\
\hline 0.0036 & 0.00225 & 0.03 & 0.02 & 1.528 & 58.19 & 2.095 & 93.79 & 12.44 \\
\hline 0.0036 & 0.00225 & 0.06 & 0.04 & 1.476 & 52.02 & 1.873 & 79.49 & 7.57 \\
\hline 0.0036 & 0.00225 & 0.09 & 0.06 & 1.419 & 50.43 & 1.815 & 72.51 & 5.75 \\
\hline 0.0036 & 0.00225 & 0.12 & 0.08 & 1.363 & 49.78 & 1.792 & 68.67 & 4.88 \\
\hline 0.0036 & 0.00225 & 0.15 & 0.09 & 1.311 & 50.13 & 1.805 & 66.65 & 4.46 \\
\hline 0.0036 & 0.00225 & 0.18 & 0.11 & 1.261 & 50.31 & 1.811 & 65.94 & 4.32 \\
\hline 0.0036 & 0.00225 & 0.21 & 0.13 & 1.215 & 52.12 & 1.876 & 66.36 & 4.41 \\
\hline 0.0036 & 0.00225 & 0.25 & 0.16 & 1.157 & 55.90 & 2.012 & 68.67 & 4.88 \\
\hline 0.0036 & 0.00225 & 0.29 & 0.18 & 1.105 & 61.90 & 2.229 & 73.49 & 5.99 \\
\hline 0.0036 & 0.00225 & 0.32 & 0.20 & 1.069 & 68.77 & 2.476 & 79.63 & 7.61 \\
\hline 0.0036 & 0.00225 & 0.36 & 0.23 & 1.024 & 90.00 & 3.240 & 99.40 & 14.81 \\
\hline 0.0036 & 0.00225 & 0.40 & 0.25 & 0.982 & 120.90 & 4.352 & 131.47 & 34.27 \\
\hline
\end{tabular}


Table D.2 (continued)

\begin{tabular}{|c|c|c|c|c|c|c|c|c|}
\hline \multirow[b]{2}{*}{$\mathrm{g}^{239} \mathrm{Pu} / \mathrm{cm}^{3}$} & \multirow[b]{2}{*}{$\begin{array}{l}\mathrm{g}^{239} \mathrm{Pu} \\
/ \mathrm{g} \mathrm{SiO}_{2}\end{array}$} & \multirow[b]{2}{*}{$\mathrm{g} \mathrm{H}_{2} \mathrm{O} / \mathrm{cm}^{3}$} & \multirow[b]{2}{*}{$\begin{array}{l}\mathrm{g} \mathrm{H}_{2} \mathrm{O} \\
/ \mathrm{g} \mathrm{SiO}_{2}\end{array}$} & \multirow[b]{2}{*}{$k_{i n f}$} & \multicolumn{2}{|c|}{ Critical slab } & \multicolumn{2}{|c|}{ Critical sphere } \\
\hline & & & & & $\begin{array}{l}\text { Thickness } \\
(\mathrm{cm})\end{array}$ & $\begin{array}{c}\text { Areal } \\
\text { density } \\
(\mathrm{kg} \\
\left.{ }^{239} \mathrm{Pu} / \mathrm{m}^{2}\right)\end{array}$ & $\begin{array}{c}\text { Radius } \\
(\mathrm{cm})\end{array}$ & $\operatorname{kg}{ }^{239} \mathrm{Pu}$ \\
\hline 0.0045 & 0.00281 & 0.00 & 0.00 & 1.557 & 79.67 & 3.585 & 139.93 & 51.64 \\
\hline 0.0045 & 0.00281 & 0.03 & 0.02 & 1.581 & 51.07 & 2.298 & 86.96 & 12.39 \\
\hline 0.0045 & 0.00281 & 0.06 & 0.04 & 1.545 & 44.68 & 2.011 & 72.32 & 7.13 \\
\hline 0.0045 & 0.00281 & 0.09 & 0.06 & 1.500 & 41.98 & 1.889 & 64.81 & 5.13 \\
\hline 0.0045 & 0.00281 & 0.12 & 0.08 & 1.453 & 40.55 & 1.825 & 60.24 & 4.12 \\
\hline 0.0045 & 0.00281 & 0.15 & 0.09 & 1.406 & 39.89 & 1.795 & 57.28 & 3.54 \\
\hline 0.0045 & 0.00281 & 0.18 & 0.11 & 1.362 & 39.80 & 1.791 & 55.39 & 3.20 \\
\hline 0.0045 & 0.00281 & 0.21 & 0.13 & 1.319 & 40.06 & 1.803 & 54.25 & 3.01 \\
\hline 0.0045 & 0.00281 & 0.25 & 0.16 & 1.266 & 41.03 & 1.846 & 53.69 & 2.92 \\
\hline 0.0045 & 0.00281 & 0.29 & 0.18 & 1.216 & 42.61 & 1.918 & 54.11 & 2.99 \\
\hline 0.0045 & 0.00281 & 0.32 & 0.20 & 1.181 & 44.30 & 1.993 & 55.06 & 3.15 \\
\hline 0.0045 & 0.00281 & 0.36 & 0.23 & 1.137 & 47.43 & 2.134 & 57.34 & 3.55 \\
\hline 0.0045 & 0.00281 & 0.40 & 0.25 & 1.097 & 51.90 & 2.336 & 61.09 & 4.30 \\
\hline 0.0055 & 0.00344 & 0.00 & 0.00 & 1.574 & 72.95 & 4.012 & 134.20 & 55.68 \\
\hline 0.0055 & 0.00344 & 0.03 & 0.02 & 1.619 & 45.53 & 2.504 & 82.18 & 12.79 \\
\hline 0.0055 & 0.00550 & 0.06 & 0.04 & 1.597 & 39.36 & 2.165 & 67.45 & 7.07 \\
\hline 0.0055 & 0.00344 & 0.09 & 0.09 & 1.562 & 36.46 & 2.005 & 59.69 & 4.90 \\
\hline 0.0055 & 0.00344 & 0.12 & 0.08 & 1.523 & 34.83 & 1.915 & 54.81 & 3.79 \\
\hline 0.0055 & 0.00344 & 0.15 & 0.09 & 1.483 & 33.88 & 1.863 & 51.46 & 3.14 \\
\hline 0.0055 & 0.00344 & 0.18 & 0.11 & 1.444 & 33.31 & 1.832 & 49.08 & 2.72 \\
\hline 0.0055 & 0.00344 & 0.21 & 0.13 & 1.406 & 33.06 & 1.818 & 47.37 & 2.45 \\
\hline 0.0055 & 0.00344 & 0.25 & 0.16 & 1.357 & 33.06 & 1.819 & 45.86 & 2.22 \\
\hline 0.0055 & 0.00344 & 0.29 & 0.18 & 1.311 & 33.42 & 1.838 & 45.01 & 2.10 \\
\hline 0.0055 & 0.00344 & 0.32 & 0.20 & 1.278 & 33.93 & 1.866 & 44.75 & 2.07 \\
\hline 0.0055 & 0.00344 & 0.36 & 0.23 & 1.237 & 34.88 & 1.918 & 44.86 & 2.08 \\
\hline 0.0055 & 0.00344 & 0.40 & 0.25 & 1.197 & 36.22 & 1.992 & 45.50 & 2.17 \\
\hline 0.0065 & 0.00406 & 0.00 & 0.00 & 1.585 & 67.84 & 4.410 & 129.88 & 59.66 \\
\hline 0.0065 & 0.00406 & 0.03 & 0.03 & 1.644 & 41.76 & 2.714 & 78.90 & 13.37 \\
\hline 0.0065 & 0.00406 & 0.06 & 0.04 & 1.632 & 35.68 & 2.319 & 64.18 & 7.20 \\
\hline 0.0065 & 0.00406 & 0.09 & 0.06 & 1.606 & 32.80 & 2.132 & 56.33 & 4.87 \\
\hline 0.0065 & 0.00406 & 0.12 & 0.08 & 1.574 & 31.11 & 2.022 & 51.30 & 3.68 \\
\hline 0.0065 & 0.004063 & 0.15 & 0.0938 & 1.540 & 30.00 & 1.950 & 47.78 & 2.97 \\
\hline 0.0065 & 0.004063 & 0.18 & 0.1125 & 1.506 & 29.28 & 1.903 & 45.19 & 2.51 \\
\hline 0.0065 & 0.004063 & 0.21 & 0.1313 & 1.472 & 28.79 & 1.871 & 43.23 & 2.20 \\
\hline
\end{tabular}


Table D.2 (continued)

\begin{tabular}{|c|c|c|c|c|c|c|c|c|}
\hline \multirow[b]{2}{*}{$\mathrm{g}^{239} \mathrm{Pu} / \mathrm{cm}^{3}$} & \multirow[b]{2}{*}{$\begin{array}{l}\mathrm{g}^{239} \mathrm{Pu} \\
/ \mathrm{g} \mathrm{SiO}_{2}\end{array}$} & \multirow[b]{2}{*}{$\mathrm{g} \mathrm{H}_{2} \mathrm{O} / \mathrm{cm}^{3}$} & \multirow[b]{2}{*}{$\begin{array}{l}\mathrm{g} \mathrm{H}_{2} \mathrm{O} \\
/ \mathrm{g} \mathrm{SiO}_{2}\end{array}$} & \multirow[b]{2}{*}{$k_{i n f}$} & \multicolumn{2}{|c|}{ Critical slab } & \multicolumn{2}{|c|}{ Critical sphere } \\
\hline & & & & & $\begin{array}{l}\text { Thickness } \\
(\mathrm{cm})\end{array}$ & $\begin{array}{c}\text { Areal } \\
\text { density } \\
(\mathrm{kg} \\
\left.{ }^{239} \mathrm{Pu} / \mathrm{m}^{2}\right)\end{array}$ & $\begin{array}{l}\text { Radius } \\
(\mathrm{cm})\end{array}$ & $\operatorname{kg}{ }^{239} \mathrm{Pu}$ \\
\hline 0.0065 & 0.004063 & 0.25 & 0.1563 & 1.427 & 28.43 & 1.848 & 41.32 & 1.92 \\
\hline 0.0065 & 0.004063 & 0.29 & 0.1813 & 1.385 & 28.34 & 1.842 & 40.00 & 1.74 \\
\hline 0.0065 & 0.004063 & 0.32 & 0.2000 & 1.354 & 28.41 & 1.846 & 39.30 & 1.65 \\
\hline 0.0065 & 0.004063 & 0.36 & 0.2250 & 1.315 & 28.68 & 1.864 & 38.71 & 1.58 \\
\hline 0.0065 & 0.004063 & 0.40 & 0.2500 & 1.278 & 29.16 & 1.895 & 38.46 & 1.55 \\
\hline 0.0100 & 0.00625 & 0.00 & 0.0000 & 1.607 & 56.99 & 5.699 & 119.78 & 71.98 \\
\hline 0.0100 & 0.00625 & 0.03 & 0.0300 & 1.685 & 34.32 & 3.432 & 72.64 & 16.05 \\
\hline 0.0100 & 0.00625 & 0.06 & 0.0375 & 1.695 & 28.69 & 2.869 & 58.07 & 8.20 \\
\hline 0.0100 & 0.00625 & 0.09 & 0.0563 & 1.688 & 25.98 & 2.598 & 50.17 & 5.29 \\
\hline 0.0100 & 0.006250 & 0.12 & 0.0750 & 1.673 & 24.30 & 2.430 & 44.99 & 3.82 \\
\hline 0.0100 & 0.00625 & 0.15 & 0.0938 & 1.654 & 23.08 & 2.308 & 41.26 & 2.94 \\
\hline 0.0100 & 0.00625 & 0.18 & 0.1125 & 1.632 & 22.20 & 2.220 & 38.44 & 2.38 \\
\hline 0.0100 & 0.00625 & 0.21 & 0.1313 & 1.610 & 21.53 & 2.153 & 36.22 & 1.99 \\
\hline 0.0100 & 0.00625 & 0.25 & 0.1563 & 1.579 & 20.81 & 2.081 & 33.89 & 1.63 \\
\hline 0.0100 & 0.00625 & 0.29 & 0.1813 & 1.548 & 20.30 & 2.030 & 32.09 & 1.38 \\
\hline 0.0100 & 0.00625 & 0.32 & 0.2000 & 1.524 & 19.98 & 1.998 & 30.99 & 1.25 \\
\hline 0.0100 & 0.00625 & 0.36 & 0.2250 & 1.494 & 19.68 & 1.968 & 29.78 & 1.11 \\
\hline 0.0100 & 0.00625 & 0.40 & 0.2500 & 1.464 & 19.45 & 1.945 & 29.15 & 1.04 \\
\hline 0.0160 & 0.01 & 0.00 & 0.0000 & 1.625 & 46.42 & 7.427 & 110.03 & 89.27 \\
\hline 0.0160 & 0.01 & 0.03 & 0.0188 & 1.707 & 28.20 & 4.512 & 67.69 & 20.79 \\
\hline 0.0160 & 0.01 & 0.06 & 0.0375 & 1.728 & 23.34 & 3.734 & 53.72 & 10.39 \\
\hline 0.0160 & 0.01 & 0.09 & 0.0563 & 1.735 & 20.90 & 3.343 & 45.94 & 6.50 \\
\hline 0.0160 & 0.01000 & 0.12 & 0.08 & 1.734 & 19.33 & 3.093 & 40.78 & 4.54 \\
\hline 0.0160 & 0.01000 & 0.15 & 0.09 & 1.728 & 18.21 & 2.914 & 37.02 & 3.40 \\
\hline 0.0160 & 0.01000 & 0.18 & 0.11 & 1.719 & 17.34 & 2.774 & 34.13 & 2.66 \\
\hline 0.0160 & 0.01000 & 0.21 & 0.13 & 1.708 & 16.65 & 2.664 & 31.83 & 2.16 \\
\hline 0.0160 & 0.01000 & 0.25 & 0.16 & 1.692 & 15.91 & 2.545 & 29.38 & 1.70 \\
\hline 0.0160 & 0.01000 & 0.29 & 0.18 & 1.674 & 15.30 & 2.448 & 27.44 & 1.38 \\
\hline 0.0160 & 0.01000 & 0.32 & 0.20 & 1.659 & 14.93 & 2.388 & 26.22 & 1.21 \\
\hline 0.0160 & 0.01000 & 0.36 & 0.23 & 1.640 & 14.49 & 2.319 & 24.85 & 1.03 \\
\hline 0.0160 & 0.01000 & 0.40 & 0.25 & 1.619 & 14.13 & 2.261 & 23.91 & 0.92 \\
\hline 0.0225 & 0.01406 & 0.00 & 0.00 & 1.636 & 39.64 & 8.919 & 103.10 & 103.30 \\
\hline 0.0225 & 0.01406 & 0.03 & 0.02 & 1.716 & 24.79 & 5.577 & 64.79 & 25.63 \\
\hline
\end{tabular}


Table D.2 (continued)

\begin{tabular}{|c|c|c|c|c|c|c|c|c|}
\hline \multirow[b]{2}{*}{$\mathrm{g}^{239} \mathrm{Pu} / \mathrm{cm}^{3}$} & \multirow[b]{2}{*}{$\begin{array}{l}\mathrm{g}{ }^{239} \mathrm{Pu} \\
/ \mathrm{g} \mathrm{SiO}_{2}\end{array}$} & \multirow[b]{2}{*}{$\mathrm{g} \mathrm{H}_{2} \mathrm{O} / \mathrm{cm}^{3}$} & \multirow[b]{2}{*}{$\begin{array}{l}\mathrm{g} \mathrm{H}_{2} \mathrm{O} \\
/ \mathrm{g} \mathrm{SiO}_{2}\end{array}$} & \multirow[b]{2}{*}{$k_{i n f}$} & \multicolumn{2}{|c|}{ Critical slab } & \multicolumn{2}{|c|}{ Critical sphere } \\
\hline & & & & & $\begin{array}{l}\text { Thickness } \\
(\mathrm{cm})\end{array}$ & $\begin{array}{c}\text { Areal } \\
\text { density } \\
(\mathrm{kg} \\
\left.{ }^{239} \mathrm{Pu} / \mathrm{m}^{2}\right)\end{array}$ & $\begin{array}{c}\text { Radius } \\
(\mathrm{cm})\end{array}$ & $\operatorname{kg}{ }^{239} \mathrm{Pu}$ \\
\hline 0.0225 & 0.01406 & 0.06 & 0.04 & 1.740 & 20.48 & 4.607 & 51.42 & 12.81 \\
\hline 0.0225 & 0.01406 & 0.09 & 0.06 & 1.751 & 18.28 & 4.112 & 43.83 & 7.94 \\
\hline 0.0225 & 0.01406 & 0.12 & 0.08 & 1.756 & 16.86 & 3.792 & 38.73 & 5.48 \\
\hline 0.0225 & 0.01406 & 0.15 & 0.09 & 1.757 & 15.82 & 3.560 & 35.00 & 4.04 \\
\hline 0.0225 & 0.01406 & 0.18 & 0.11 & 1.755 & 15.02 & 3.379 & 32.11 & 3.12 \\
\hline 0.0225 & 0.01406 & 0.21 & 0.13 & 1.750 & 14.36 & 3.231 & 29.79 & 2.49 \\
\hline 0.0225 & 0.01406 & 0.25 & 0.16 & 1.742 & 13.65 & 3.071 & 27.32 & 1.92 \\
\hline 0.0225 & 0.01406 & 0.29 & 0.18 & 1.732 & 13.01 & 2.927 & 25.35 & 1.54 \\
\hline 0.0225 & 0.02250 & 0.32 & 0.20 & 1.724 & 12.63 & 2.842 & 24.11 & 1.32 \\
\hline 0.0225 & 0.01406 & 0.36 & 0.23 & 1.711 & 12.20 & 2.744 & 22.70 & 1.10 \\
\hline 0.0225 & 0.01406 & 0.40 & 0.25 & 1.698 & 11.82 & 2.660 & 21.65 & 0.96 \\
\hline 0.08 & 0.05000 & 0.00 & 0.00 & 1.691 & 20.38 & 16.302 & 78.70 & 163.32 \\
\hline 0.08 & 0.05000 & 0.03 & 0.02 & 1.756 & 14.84 & 11.868 & 54.42 & 54.00 \\
\hline 0.08 & 0.05000 & 0.06 & 0.04 & 1.769 & 12.91 & 10.329 & 44.49 & 29.52 \\
\hline 0.08 & 0.05000 & 0.09 & 0.06 & 1.775 & 11.78 & 9.426 & 38.33 & 18.87 \\
\hline 0.08 & 0.05000 & 0.12 & 0.08 & 1.780 & 10.97 & 8.779 & 33.98 & 13.14 \\
\hline 0.08 & 0.05000 & 0.15 & 0.09 & 1.784 & 10.50 & 8.398 & 30.96 & 9.95 \\
\hline 0.08 & 0.05000 & 0.18 & 0.11 & 1.788 & 9.79 & 7.835 & 28.03 & 7.38 \\
\hline 0.08 & 0.05000 & 0.21 & 0.13 & 1.791 & 9.33 & 7.464 & 25.87 & 5.80 \\
\hline 0.08 & 0.05000 & 0.25 & 0.16 & 1.795 & 8.80 & 7.037 & 23.52 & 4.36 \\
\hline 0.08 & 0.05000 & 0.29 & 0.18 & 1.798 & 8.34 & 6.669 & 21.61 & 3.38 \\
\hline 0.08 & 0.05000 & 0.32 & 0.20 & 1.800 & 8.03 & 6.424 & 20.40 & 2.84 \\
\hline 0.08 & 0.05000 & 0.36 & 0.23 & 1.801 & 7.66 & 6.131 & 18.99 & 2.30 \\
\hline 0.08 & 0.05000 & 0.40 & 0.25 & 1.803 & 7.50 & 5.999 & 18.05 & 1.97 \\
\hline 0.25 & 0.15625 & 0.00 & 0.00 & 1.861 & 8.61 & 21.535 & 54.10 & 165.83 \\
\hline 0.25 & 0.15625 & 0.03 & 0.02 & 1.853 & 7.85 & 19.635 & 42.60 & 80.97 \\
\hline 0.25 & 0.15625 & 0.06 & 0.04 & 1.845 & 7.62 & 19.058 & 36.65 & 51.55 \\
\hline 0.25 & 0.15625 & 0.09 & 0.06 & 1.838 & 7.45 & 18.615 & 32.51 & 35.98 \\
\hline 0.25 & 0.15625 & 0.12 & 0.08 & 1.832 & 7.27 & 18.165 & 29.37 & 26.54 \\
\hline 0.25 & 0.15625 & 0.15 & 0.09 & 1.827 & 7.20 & 17.998 & 27.14 & 20.94 \\
\hline 0.25 & 0.15625 & 0.18 & 0.11 & 1.823 & 6.87 & 17.185 & 24.83 & 16.02 \\
\hline 0.25 & 0.15625 & 0.21 & 0.13 & 1.820 & 6.67 & 16.683 & 23.10 & 12.90 \\
\hline 0.25 & 0.15625 & 0.25 & 0.16 & 1.818 & 6.41 & 16.020 & 21.17 & 9.93 \\
\hline 0.25 & 0.15625 & 0.29 & 0.18 & 1.816 & 6.15 & 15.380 & 19.56 & 7.83 \\
\hline
\end{tabular}


Table D.2 (continued)

\begin{tabular}{|c|c|c|c|c|c|c|c|c|}
\hline \multirow[b]{2}{*}{$\mathrm{g}^{239} \mathrm{Pu} / \mathrm{cm}^{3}$} & \multirow[b]{2}{*}{$\begin{array}{l}\mathrm{g}{ }^{239} \mathrm{Pu} \\
/ \mathrm{g} \mathrm{SiO}_{2}\end{array}$} & \multirow[b]{2}{*}{$\mathrm{g} \mathrm{H}_{2} \mathrm{O} / \mathrm{cm}^{3}$} & \multirow[b]{2}{*}{$\begin{array}{l}\mathrm{g} \mathrm{H}_{2} \mathrm{O} \\
/ \mathrm{g} \mathrm{SiO}_{2}\end{array}$} & \multirow[b]{2}{*}{$k_{i n f}$} & \multicolumn{2}{|c|}{ Critical slab } & \multicolumn{2}{|c|}{ Critical sphere } \\
\hline & & & & & $\begin{array}{l}\text { Thickness } \\
(\mathrm{cm})\end{array}$ & $\begin{array}{c}\text { Areal } \\
\text { density } \\
(\mathrm{kg} \\
\left.{ }^{239} \mathrm{Pu} / \mathrm{m}^{2}\right)\end{array}$ & $\begin{array}{c}\text { Radius } \\
(\mathrm{cm})\end{array}$ & $\operatorname{kg}{ }^{239} \mathrm{Pu}$ \\
\hline 0.25 & 0.15625 & 0.32 & 0.20 & 1.815 & 5.97 & 14.923 & 18.51 & 6.64 \\
\hline 0.25 & 0.15625 & 0.36 & 0.23 & 1.814 & 5.74 & 14.340 & 17.29 & 5.41 \\
\hline 0.25 & 0.15625 & 0.39 & 0.24 & 1.814 & 5.70 & 14.240 & 16.78 & 4.95 \\
\hline 1 & 0.62500 & 0.00 & 0.00 & 2.311 & 2.42 & 24.220 & 27.89 & 90.88 \\
\hline 1 & 0.62500 & 0.03 & 0.03 & 2.157 & 2.65 & 26.460 & 25.61 & 70.40 \\
\hline 1 & 0.62500 & 0.06 & 0.04 & 2.091 & 2.89 & 28.870 & 23.80 & 56.48 \\
\hline 1 & 0.62500 & 0.09 & 0.06 & 2.051 & 3.10 & 30.960 & 22.21 & 45.89 \\
\hline 1 & 0.62500 & 0.12 & 0.08 & 2.022 & 3.26 & 32.620 & 20.82 & 37.82 \\
\hline 1 & 0.62500 & 0.15 & 0.09 & 2.000 & 3.42 & 34.220 & 19.74 & 32.20 \\
\hline 1 & 0.62500 & 0.18 & 0.11 & 1.981 & 3.47 & 34.690 & 18.53 & 26.67 \\
\hline 1 & 0.62500 & 0.21 & 0.13 & 1.966 & 3.52 & 35.230 & 17.58 & 22.76 \\
\hline 1 & 0.62500 & 0.25 & 0.16 & 1.949 & 3.56 & 35.570 & 16.46 & 18.67 \\
\hline 1 & 0.62500 & 0.29 & 0.18 & 1.936 & 3.56 & 35.600 & 15.48 & 15.52 \\
\hline 1 & 0.62500 & 0.32 & 0.20 & 1.927 & 3.55 & 35.470 & 14.82 & 13.63 \\
\hline 1 & 0.62500 & 0.35 & 0.22 & 1.919 & 3.57 & 35.650 & 14.34 & 12.35 \\
\hline
\end{tabular}


Table D.3 Plutonium isotopic mixture systems

\begin{tabular}{|c|c|c|c|c|c|c|c|c|}
\hline \multirow[b]{2}{*}{$\mathrm{g} \mathrm{Pu} / \mathrm{cm}^{3}$} & \multirow[b]{2}{*}{$\mathrm{g} \mathrm{Pu} / \mathrm{g} \mathrm{SiO}_{2}$} & \multirow[b]{2}{*}{$\mathrm{g} \mathrm{H}_{2} \mathrm{O} / \mathrm{cm}^{3}$} & \multirow[b]{2}{*}{$\begin{array}{l}\mathrm{g} \mathrm{H}_{2} \mathrm{O} \\
/ \mathrm{g} \mathrm{SiO}_{2} \\
\end{array}$} & \multirow[b]{2}{*}{$k_{i n f}$} & \multicolumn{2}{|c|}{ Critical slab } & \multicolumn{2}{|c|}{ Critical sphere } \\
\hline & & & & & $\begin{array}{l}\text { Thickness } \\
(\mathrm{cm})\end{array}$ & $\begin{array}{c}\text { Areal } \\
\text { density } \\
\left(\mathrm{kg} \mathrm{Pu} / \mathrm{m}^{2}\right)\end{array}$ & $\begin{array}{c}\text { Radius } \\
(\mathrm{cm})\end{array}$ & $\mathrm{kg} \mathrm{Pu}$ \\
\hline 0.00089 & 0.00056 & 0.00 & 0.00 & 0.952 & 5273.13 & 46.931 & 2671.32 & 71065.10 \\
\hline 0.00090 & 0.00056 & 0.00 & 0.00 & 0.956 & 2138.41 & 19.246 & 1782.73 & 21359.34 \\
\hline 0.00095 & 0.00059 & 0.00 & 0.00 & 0.974 & 869.90 & 8.264 & 896.33 & 2865.64 \\
\hline 0.00100 & 0.00063 & 0.00 & 0.00 & 0.990 & 641.04 & 6.410 & 693.17 & 1395.09 \\
\hline 0.00110 & 0.00069 & 0.00 & 0.00 & 1.019 & 463.07 & 5.094 & 518.05 & 640.63 \\
\hline 0.00110 & 0.00069 & 0.03 & 0.02 & 0.953 & 861.37 & 9.475 & 930.44 & 3711.50 \\
\hline 0.00125 & 0.00078 & 0.00 & 0.00 & 1.053 & 363.71 & 4.546 & 422.04 & 393.60 \\
\hline 0.00125 & 0.00078 & 0.03 & 0.02 & 1.008 & 332.26 & 4.153 & 344.07 & 213.27 \\
\hline 0.00150 & 0.00094 & 0.00 & 0.00 & 1.094 & 288.10 & 4.321 & 347.26 & 263.11 \\
\hline 0.00150 & 0.00094 & 0.03 & 0.02 & 1.084 & 196.68 & 2.950 & 224.73 & 71.31 \\
\hline 0.00150 & 0.00094 & 0.06 & 0.04 & 1.008 & 247.54 & 3.713 & 274.09 & 129.38 \\
\hline 0.00165 & 0.00103 & 0.00 & 0.00 & 1.110 & 263.60 & 4.349 & 323.65 & 234.31 \\
\hline 0.00165 & 0.00103 & 0.03 & 0.02 & 1.122 & 165.57 & 2.732 & 196.11 & 52.12 \\
\hline 0.00165 & 0.00103 & 0.06 & 0.04 & 1.050 & 181.80 & 3.000 & 208.13 & 62.31 \\
\hline 0.00165 & 0.00103 & 0.09 & 0.06 & 0.980 & 294.49 & 4.859 & 315.65 & 217.37 \\
\hline 0.0018 & 0.00113 & 0.00 & 0.00 & 1.123 & 246.11 & 4.430 & 307.44 & 219.09 \\
\hline 0.0018 & 0.00113 & 0.03 & 0.02 & 1.154 & 146.48 & 2.637 & 177.57 & 42.22 \\
\hline 0.0018 & 0.00113 & 0.06 & 0.04 & 1.088 & 148.77 & 2.678 & 175.25 & 40.58 \\
\hline 0.0018 & 0.00113 & 0.09 & 0.06 & 1.020 & 189.63 & 3.413 & 211.57 & 71.41 \\
\hline 0.0018 & 0.00113 & 0.12 & 0.08 & 0.957 & 450.70 & 8.113 & 476.95 & 818.03 \\
\hline 0.0020 & 0.00125 & 0.00 & 0.00 & 1.134 & 229.91 & 4.598 & 291.99 & 208.56 \\
\hline 0.0020 & 0.00125 & 0.03 & 0.02 & 1.191 & 129.25 & 2.585 & 160.71 & 34.77 \\
\hline 0.0020 & 0.00125 & 0.06 & 0.04 & 1.132 & 126.69 & 2.534 & 150.12 & 28.34 \\
\hline 0.0020 & 0.00125 & 0.09 & 0.06 & 1.067 & 139.31 & 2.786 & 161.47 & 35.27 \\
\hline 0.0020 & 0.00125 & 0.12 & 0.08 & 1.006 & 186.55 & 3.731 & 205.39 & 72.58 \\
\hline 0.0020 & 0.00125 & 0.15 & 0.09 & 0.950 & 599.80 & 11.996 & 631.19 & 2106.69 \\
\hline
\end{tabular}


Table D.3 (continued)

\begin{tabular}{|c|c|c|c|c|c|c|c|c|}
\hline \multirow[b]{2}{*}{$\mathrm{g} \mathrm{Pu} / \mathrm{cm}^{3}$} & \multirow[b]{2}{*}{$\mathrm{g} \mathrm{Pu} / \mathrm{g} \mathrm{SiO}_{2}$} & \multirow[b]{2}{*}{$\mathrm{g} \mathrm{H}_{2} \mathrm{O} / \mathrm{cm}^{3}$} & \multirow[b]{2}{*}{$\begin{array}{l}\mathrm{g} \mathrm{H}_{2} \mathrm{O} \\
/ \mathrm{g} \mathrm{SiO}_{2}\end{array}$} & \multirow[b]{2}{*}{$k_{i n f}$} & \multicolumn{2}{|c|}{ Critical slab } & \multicolumn{2}{|c|}{ Critical sphere } \\
\hline & & & & & $\begin{array}{c}\text { Thickness } \\
(\mathrm{cm})\end{array}$ & $\begin{array}{c}\text { Areal } \\
\text { density } \\
\left(\mathrm{kg} \mathrm{Pu} / \mathrm{m}^{2}\right)\end{array}$ & $\begin{array}{l}\text { Radius } \\
(\mathrm{cm})\end{array}$ & $\mathrm{kg} \mathrm{Pu}$ \\
\hline 0.0022 & 0.00138 & 0.00 & 0.00 & 1.142 & 218.08 & 4.798 & 281.13 & 204.76 \\
\hline 0.0022 & 0.00138 & 0.03 & 0.02 & 1.222 & 113.69 & 2.501 & 148.97 & 30.46 \\
\hline 0.0022 & 0.00138 & 0.06 & 0.04 & 1.171 & 109.81 & 2.416 & 134.41 & 22.38 \\
\hline 0.0022 & 0.00138 & 0.09 & 0.06 & 1.109 & 114.15 & 2.511 & 136.67 & 23.53 \\
\hline 0.0022 & 0.00138 & 0.12 & 0.08 & 1.050 & 134.02 & 2.949 & 153.30 & 33.20 \\
\hline 0.0022 & 0.00138 & 0.15 & 0.09 & 0.995 & 186.83 & 4.110 & 203.71 & 77.90 \\
\hline 0.0025 & 0.00156 & 0.00 & 0.00 & 1.148 & 205.87 & 5.147 & 270.62 & 207.54 \\
\hline 0.0025 & 0.00156 & 0.03 & 0.02 & 1.260 & 100.95 & 2.524 & 136.83 & 26.83 \\
\hline 0.0025 & 0.00156 & 0.06 & 0.04 & 1.219 & 91.75 & 2.294 & 119.19 & 17.73 \\
\hline 0.0025 & 0.00156 & 0.09 & 0.06 & 1.164 & 92.90 & 2.323 & 115.62 & 16.18 \\
\hline 0.0025 & 0.00156 & 0.12 & 0.08 & 1.108 & 100.35 & 2.509 & 119.95 & 18.07 \\
\hline 0.0025 & 0.00156 & 0.15 & 0.09 & 1.055 & 121.96 & 3.049 & 138.04 & 27.55 \\
\hline 0.0025 & 0.00156 & 0.18 & 0.11 & 1.006 & 151.63 & 3.791 & 167.10 & 48.86 \\
\hline 0.0025 & 0.00156 & 0.21 & 0.13 & 0.960 & 299.25 & 7.481 & 324.99 & 359.46 \\
\hline 0.0028 & 0.00175 & 0.00 & 0.00 & 1.149 & 197.46 & 5.529 & 263.48 & 214.54 \\
\hline 0.0028 & 0.00175 & 0.03 & 0.02 & 1.289 & 92.09 & 2.579 & 128.39 & 24.82 \\
\hline 0.0028 & 0.00175 & 0.06 & 0.04 & 1.259 & 81.54 & 2.283 & 109.25 & 15.29 \\
\hline 0.0028 & 0.00175 & 0.09 & 0.06 & 1.209 & 80.14 & 2.244 & 103.06 & 12.84 \\
\hline 0.0028 & 0.00175 & 0.12 & 0.08 & 1.157 & 83.05 & 2.325 & 102.82 & 12.75 \\
\hline 0.0028 & 0.00175 & 0.15 & 0.09 & 1.106 & 90.05 & 2.521 & 107.48 & 14.56 \\
\hline 0.0028 & 0.00175 & 0.18 & 0.11 & 1.058 & 103.03 & 2.885 & 118.63 & 19.58 \\
\hline 0.0028 & 0.00175 & 0.21 & 0.13 & 1.014 & 128.55 & 3.599 & 142.65 & 34.05 \\
\hline 0.0028 & 0.00175 & 0.25 & 0.16 & 0.959 & 279.76 & 7.833 & 297.00 & 307.26 \\
\hline 0.0032 & 0.00200 & 0.00 & 0.00 & 1.147 & 189.72 & 6.071 & 257.43 & 228.68 \\
\hline 0.0032 & 0.00200 & 0.03 & 0.02 & 1.319 & 83.61 & 2.675 & 120.49 & 23.45 \\
\hline 0.0032 & 0.00200 & 0.06 & 0.04 & 1.302 & 72.20 & 2.310 & 100.27 & 13.51 \\
\hline 0.0032 & 0.00200 & 0.09 & 0.06 & 1.259 & 69.82 & 2.234 & 92.32 & 10.55 \\
\hline 0.0032 & 0.00200 & 0.12 & 0.08 & 1.212 & 70.22 & 2.247 & 89.39 & 9.57 \\
\hline 0.0032 & 0.00200 & 0.15 & 0.09 & 1.165 & 72.69 & 2.326 & 89.68 & 9.67 \\
\hline 0.0032 & 0.00200 & 0.18 & 0.11 & 1.119 & 77.91 & 2.493 & 92.98 & 10.78 \\
\hline 0.0032 & 0.00200 & 0.21 & 0.13 & 1.076 & 86.34 & 2.763 & 100.08 & 13.43 \\
\hline 0.0032 & 0.00200 & 0.25 & 0.16 & 1.023 & 108.47 & 3.471 & 120.39 & 23.39 \\
\hline 0.0032 & 0.00200 & 0.29 & 0.18 & 0.974 & 176.58 & 5.650 & 186.86 & 87.45 \\
\hline
\end{tabular}


Table D.3 (continued)

\begin{tabular}{|c|c|c|c|c|c|c|c|c|}
\hline \multirow[b]{2}{*}{$\mathrm{g} \mathrm{Pu} / \mathrm{cm}^{3}$} & \multirow[b]{2}{*}{$\mathrm{g} \mathrm{Pu} / \mathrm{g} \mathrm{SiO}_{2}$} & \multirow[b]{2}{*}{$\mathrm{g} \mathrm{H}_{2} \mathrm{O} / \mathrm{cm}^{3}$} & \multirow[b]{2}{*}{$\begin{array}{l}\mathrm{g} \mathrm{H}_{2} \mathrm{O} \\
/ \mathrm{g} \mathrm{SiO}_{2}\end{array}$} & \multirow[b]{2}{*}{$k_{i n f}$} & \multicolumn{2}{|c|}{ Critical slab } & \multicolumn{2}{|c|}{ Critical sphere } \\
\hline & & & & & $\begin{array}{c}\text { Thickness } \\
(\mathrm{cm})\end{array}$ & $\begin{array}{c}\text { Areal } \\
\text { density } \\
\left(\mathrm{kg} \mathrm{Pu} / \mathrm{m}^{2}\right)\end{array}$ & $\begin{array}{l}\text { Radius } \\
(\mathrm{cm})\end{array}$ & $\mathrm{kg} \mathrm{Pu}$ \\
\hline 0.0036 & 0.00225 & 0.00 & 0.00 & 1.143 & 184.19 & 6.631 & 253.48 & 245.59 \\
\hline 0.0036 & 0.00225 & 0.03 & 0.02 & 1.341 & 77.51 & 2.790 & 114.91 & 22.88 \\
\hline 0.0036 & 0.00225 & 0.06 & 0.04 & 1.335 & 65.68 & 2.364 & 93.98 & 12.52 \\
\hline 0.0036 & 0.00225 & 0.09 & 0.06 & 1.300 & 64.48 & 2.321 & 85.15 & 9.31 \\
\hline 0.0036 & 0.00225 & 0.12 & 0.08 & 1.258 & 63.81 & 2.297 & 80.92 & 7.99 \\
\hline 0.0036 & 0.00225 & 0.15 & 0.09 & 1.214 & 64.98 & 2.339 & 79.34 & 7.53 \\
\hline 0.0036 & 0.00225 & 0.18 & 0.11 & 1.171 & 67.77 & 2.440 & 79.81 & 7.67 \\
\hline 0.0036 & 0.00225 & 0.21 & 0.13 & 1.129 & 67.80 & 2.441 & 82.23 & 8.38 \\
\hline 0.0036 & 0.00225 & 0.25 & 0.16 & 1.078 & 76.48 & 2.753 & 89.38 & 10.77 \\
\hline 0.0036 & 0.00225 & 0.29 & 0.18 & 1.030 & 92.76 & 3.339 & 104.51 & 17.21 \\
\hline 0.0036 & 0.00225 & 0.32 & 0.20 & 0.996 & 117.83 & 4.242 & 129.31 & 32.61 \\
\hline 0.0036 & 0.00225 & 0.36 & 0.23 & 0.955 & 277.25 & 9.981 & 295.38 & 388.63 \\
\hline 0.0045 & 0.00281 & 0.00 & 0.00 & 1.132 & 175.46 & 7.896 & 247.36 & 285.30 \\
\hline 0.0045 & 0.00281 & 0.03 & 0.02 & 1.371 & 69.06 & 3.108 & 106.79 & 22.96 \\
\hline 0.0045 & 0.00281 & 0.06 & 0.04 & 1.388 & 56.55 & 2.545 & 85.12 & 11.62 \\
\hline 0.0045 & 0.00281 & 0.09 & 0.06 & 1.368 & 51.95 & 2.338 & 75.30 & 8.05 \\
\hline 0.0045 & 0.00281 & 0.12 & 0.08 & 1.335 & 51.47 & 2.316 & 69.80 & 6.41 \\
\hline 0.0045 & 0.00281 & 0.15 & 0.09 & 1.299 & 50.80 & 2.286 & 66.54 & 5.55 \\
\hline 0.0045 & 0.00281 & 0.18 & 0.11 & 1.262 & 51.02 & 2.296 & 64.73 & 5.11 \\
\hline 0.0045 & 0.00281 & 0.21 & 0.13 & 1.225 & 52.01 & 2.341 & 63.99 & 4.94 \\
\hline 0.0045 & 0.00281 & 0.25 & 0.16 & 1.178 & 51.67 & 2.325 & 64.47 & 5.05 \\
\hline 0.0045 & 0.00281 & 0.29 & 0.18 & 1.133 & 55.04 & 2.477 & 66.62 & 5.57 \\
\hline 0.0045 & 0.00281 & 0.32 & 0.20 & 1.101 & 58.75 & 2.644 & 69.59 & 6.35 \\
\hline 0.0045 & 0.00281 & 0.36 & 0.23 & 1.061 & 66.27 & 2.982 & 76.23 & 8.35 \\
\hline 0.0045 & 0.00281 & 0.40 & 0.25 & 1.023 & 83.05 & 3.737 & 91.93 & 14.65 \\
\hline 0.0055 & 0.00344 & 0.00 & 0.00 & 1.122 & 167.51 & 9.213 & 241.53 & 324.60 \\
\hline 0.0055 & 0.00344 & 0.03 & 0.02 & 1.387 & 62.46 & 3.436 & 101.55 & 24.13 \\
\hline 0.0055 & 0.00344 & 0.06 & 0.04 & 1.423 & 50.14 & 2.758 & 79.36 & 11.52 \\
\hline 0.0055 & 0.00344 & 0.09 & 0.06 & 1.416 & 45.14 & 2.483 & 69.10 & 7.60 \\
\hline 0.0055 & 0.00344 & 0.12 & 0.08 & 1.394 & 42.55 & 2.340 & 63.03 & 5.77 \\
\hline 0.0055 & 0.00344 & 0.15 & 0.09 & 1.366 & 41.15 & 2.263 & 59.10 & 4.76 \\
\hline 0.0055 & 0.00344 & 0.18 & 0.11 & 1.335 & 41.92 & 2.306 & 56.46 & 4.15 \\
\hline 0.0055 & 0.00344 & 0.21 & 0.13 & 1.303 & 41.78 & 2.298 & 54.70 & 3.77 \\
\hline
\end{tabular}


Table D.3 (continued)

\begin{tabular}{|c|c|c|c|c|c|c|c|c|}
\hline \multirow[b]{2}{*}{$\mathrm{g} \mathrm{Pu} / \mathrm{cm}^{3}$} & \multirow[b]{2}{*}{$\mathrm{g} \mathrm{Pu} / \mathrm{g} \mathrm{SiO}_{2}$} & \multirow[b]{2}{*}{$\mathrm{g} \mathrm{H}_{2} \mathrm{O} / \mathrm{cm}^{3}$} & \multirow[b]{2}{*}{$\begin{array}{l}\mathrm{g} \mathrm{H}_{2} \mathrm{O} \\
/ \mathrm{g} \mathrm{SiO}_{2}\end{array}$} & \multirow[b]{2}{*}{$k_{i n f}$} & \multicolumn{2}{|c|}{ Critical slab } & \multicolumn{2}{|c|}{ Critical sphere } \\
\hline & & & & & $\begin{array}{c}\text { Thickness } \\
(\mathrm{cm})\end{array}$ & $\begin{array}{c}\text { Areal } \\
\text { density } \\
\left(\mathrm{kg} \mathrm{Pu} / \mathrm{m}^{2}\right)\end{array}$ & $\begin{array}{l}\text { Radius } \\
(\mathrm{cm})\end{array}$ & $\mathrm{kg} \mathrm{Pu}$ \\
\hline 0.0055 & 0.00344 & 0.25 & 0.16 & 1.261 & 42.21 & 2.322 & 53.38 & 3.51 \\
\hline 0.0055 & 0.00344 & 0.29 & 0.18 & 1.220 & 41.24 & 2.268 & 53.00 & 3.43 \\
\hline 0.0055 & 0.00344 & 0.32 & 0.20 & 1.191 & 42.31 & 2.327 & 53.28 & 3.48 \\
\hline 0.0055 & 0.00344 & 0.36 & 0.23 & 1.153 & 44.31 & 2.437 & 54.41 & 3.71 \\
\hline 0.0055 & 0.00344 & 0.40 & 0.25 & 1.117 & 47.20 & 2.596 & 56.57 & 4.17 \\
\hline 0.0065 & 0.00406 & 0.00 & 0.00 & 1.117 & 159.56 & 10.371 & 234.62 & 351.64 \\
\hline 0.0065 & 0.00406 & 0.03 & 0.02 & 1.393 & 58.41 & 3.797 & 98.18 & 25.77 \\
\hline 0.0065 & 0.00406 & 0.06 & 0.04 & 1.444 & 46.07 & 2.994 & 75.72 & 11.82 \\
\hline 0.0065 & 0.00406 & 0.09 & 0.06 & 1.448 & 40.91 & 2.659 & 65.18 & 7.54 \\
\hline 0.0065 & 0.00406 & 0.12 & 0.08 & 1.435 & 38.20 & 2.483 & 58.84 & 5.55 \\
\hline 0.0065 & 0.00406 & 0.15 & 0.09 & 1.413 & 36.47 & 2.370 & 54.61 & 4.43 \\
\hline 0.0065 & 0.00406 & 0.18 & 0.11 & 1.388 & 35.43 & 2.303 & 51.60 & 3.74 \\
\hline 0.0065 & 0.00406 & 0.21 & 0.13 & 1.361 & 34.81 & 2.263 & 49.43 & 3.29 \\
\hline 0.0065 & 0.00406 & 0.25 & 0.16 & 1.324 & 34.39 & 2.235 & 47.42 & 2.90 \\
\hline 0.0065 & 0.00406 & 0.29 & 0.18 & 1.287 & 34.39 & 2.235 & 46.18 & 2.68 \\
\hline 0.0065 & 0.00406 & 0.32 & 0.20 & 1.260 & 34.66 & 2.253 & 45.66 & 2.59 \\
\hline 0.0065 & 0.00406 & 0.36 & 0.23 & 1.225 & 35.29 & 2.294 & 45.42 & 2.55 \\
\hline 0.0065 & 0.00406 & 0.40 & 0.25 & 1.192 & 36.32 & 2.361 & 45.69 & 2.60 \\
\hline 0.0100 & 0.00625 & 0.00 & 0.0000 & 1.130 & 130.56 & 13.056 & 205.73 & 364.72 \\
\hline 0.0100 & 0.00625 & 0.03 & 0.0188 & 1.389 & 50.53 & 5.053 & 92.29 & 32.93 \\
\hline 0.0100 & 0.00625 & 0.06 & 0.0375 & 1.468 & 38.14 & 3.814 & 69.40 & 14.00 \\
\hline 0.0100 & 0.00625 & 0.09 & 0.0563 & 1.497 & 33.10 & 3.310 & 58.44 & 8.36 \\
\hline 0.0100 & 0.00625 & 0.12 & 0.0750 & 1.504 & 30.24 & 3.024 & 51.72 & 5.79 \\
\hline 0.0100 & 0.00625 & 0.15 & 0.0938 & 1.500 & 28.27 & 2.827 & 47.08 & 4.37 \\
\hline 0.0100 & 0.00625 & 0.18 & 0.1125 & 1.490 & 26.94 & 2.694 & 43.65 & 3.48 \\
\hline 0.0100 & 0.00625 & 0.21 & 0.1313 & 1.477 & 25.94 & 2.594 & 41.01 & 2.89 \\
\hline 0.0100 & 0.00625 & 0.25 & 0.1563 & 1.455 & 24.92 & 2.492 & 38.32 & 2.36 \\
\hline 0.0100 & 0.00625 & 0.29 & 0.1813 & 1.431 & 24.23 & 2.423 & 36.28 & 2.00 \\
\hline 0.0100 & 0.00625 & 0.32 & 0.2000 & 1.412 & 23.82 & 2.382 & 35.06 & 1.81 \\
\hline 0.0100 & 0.00625 & 0.36 & 0.2250 & 1.387 & 23.46 & 2.346 & 33.76 & 1.61 \\
\hline 0.0100 & 0.00625 & 0.40 & 0.2500 & 1.361 & 23.23 & 2.323 & 32.74 & 1.47 \\
\hline 0.0160 & 0.01 & 0.00 & 0.0000 & 1.203 & 94.20 & 15.071 & 165.02 & 301.15 \\
\hline 0.0160 & 0.01 & 0.03 & 0.0188 & 1.372 & 43.76 & 7.001 & 87.98 & 45.64 \\
\hline 0.0160 & 0.01 & 0.06 & 0.0375 & 1.460 & 32.71 & 5.233 & 65.56 & 18.88 \\
\hline
\end{tabular}


Table D.3 (continued)

\begin{tabular}{|c|c|c|c|c|c|c|c|c|}
\hline \multirow[b]{2}{*}{$\mathrm{g} \mathrm{Pu} / \mathrm{cm}^{3}$} & \multirow[b]{2}{*}{$\mathrm{g} \mathrm{Pu} / \mathrm{g} \mathrm{SiO}_{2}$} & \multirow[b]{2}{*}{$\mathrm{g} \mathrm{H}_{2} \mathrm{O} / \mathrm{cm}^{3}$} & \multirow[b]{2}{*}{$\begin{array}{l}\mathrm{g} \mathrm{H}_{2} \mathrm{O} \\
/ \mathrm{g} \mathrm{SiO}_{2} \\
\end{array}$} & \multirow[b]{2}{*}{$k_{i n f}$} & \multicolumn{2}{|c|}{ Critical slab } & \multicolumn{2}{|c|}{ Critical sphere } \\
\hline & & & & & $\begin{array}{l}\text { Thickness } \\
(\mathrm{cm})\end{array}$ & $\begin{array}{c}\text { Areal } \\
\text { density } \\
\left(\mathrm{kg} \mathrm{Pu} / \mathrm{m}^{2}\right)\end{array}$ & $\begin{array}{l}\text { Radius } \\
(\mathrm{cm})\end{array}$ & $\mathrm{kg} \mathrm{Pu}$ \\
\hline 0.0160 & 0.01 & 0.09 & 0.0563 & 1.505 & 27.83 & 4.452 & 54.42 & 10.80 \\
\hline 0.0160 & 0.01 & 0.12 & 0.0750 & 1.529 & 25.00 & 4.000 & 47.48 & 7.17 \\
\hline 0.0160 & 0.01 & 0.15 & 0.0938 & 1.541 & 23.10 & 3.696 & 42.63 & 5.19 \\
\hline 0.0160 & 0.01 & 0.18 & 0.1125 & 1.546 & 21.58 & 3.452 & 39.01 & 3.98 \\
\hline 0.0160 & 0.01 & 0.21 & 0.1313 & 1.546 & 20.50 & 3.280 & 36.18 & 3.17 \\
\hline 0.0160 & 0.01 & 0.25 & 0.1563 & 1.541 & 19.39 & 3.103 & 33.24 & 2.46 \\
\hline 0.0160 & 0.01 & 0.29 & 0.1813 & 1.531 & 18.53 & 2.965 & 30.94 & 1.98 \\
\hline 0.0160 & 0.01 & 0.32 & 0.2000 & 1.523 & 17.95 & 2.871 & 29.52 & 1.72 \\
\hline 0.0160 & 0.01 & 0.36 & 0.2250 & 1.509 & 17.36 & 2.778 & 27.93 & 1.46 \\
\hline 0.0160 & 0.01000 & 0.40 & 0.25 & 1.495 & 16.88 & 2.701 & 26.84 & 1.30 \\
\hline 0.0225 & 0.01406 & 0.00 & 0.00 & 1.292 & 72.32 & 16.272 & 139.16 & 254.00 \\
\hline 0.0225 & 0.01406 & 0.03 & 0.02 & 1.366 & 39.74 & 8.940 & 84.68 & 57.23 \\
\hline 0.0225 & 0.01406 & 0.06 & 0.04 & 1.446 & 29.69 & 6.680 & 63.66 & 24.32 \\
\hline 0.0225 & 0.01406 & 0.09 & 0.06 & 1.494 & 24.97 & 5.619 & 52.67 & 13.77 \\
\hline 0.0225 & 0.01406 & 0.12 & 0.08 & 1.524 & 22.25 & 5.006 & 45.69 & 8.99 \\
\hline 0.0225 & 0.01406 & 0.15 & 0.09 & 1.544 & 20.39 & 4.588 & 40.77 & 6.39 \\
\hline 0.0225 & 0.01406 & 0.18 & 0.11 & 1.557 & 19.01 & 4.277 & 37.07 & 4.80 \\
\hline 0.0225 & 0.01406 & 0.21 & 0.13 & 1.564 & 17.90 & 4.026 & 34.16 & 3.76 \\
\hline 0.0225 & 0.01406 & 0.25 & 0.16 & 1.569 & 16.77 & 3.772 & 31.12 & 2.84 \\
\hline 0.0225 & 0.01406 & 0.29 & 0.18 & 1.569 & 16.02 & 3.605 & 28.73 & 2.24 \\
\hline 0.0225 & 0.01406 & 0.32 & 0.20 & 1.567 & 15.47 & 3.481 & 27.25 & 1.91 \\
\hline 0.0225 & 0.01406 & 0.36 & 0.23 & 1.562 & 14.84 & 3.340 & 25.57 & 1.58 \\
\hline 0.0225 & 0.01406 & 0.40 & 0.25 & 1.555 & 14.32 & 3.221 & 24.37 & 1.36 \\
\hline 0.0800 & 0.05000 & 0.00 & 0.00 & 1.632 & 30.62 & 24.494 & 86.31 & 215.49 \\
\hline 0.0800 & 0.05000 & 0.03 & 0.02 & 1.486 & 22.98 & 18.385 & 64.98 & 91.95 \\
\hline 0.0800 & 0.05000 & 0.06 & 0.04 & 1.465 & 19.90 & 15.921 & 54.44 & 54.07 \\
\hline 0.0800 & 0.05000 & 0.09 & 0.06 & 1.470 & 17.81 & 14.246 & 47.07 & 34.96 \\
\hline 0.0800 & 0.05000 & 0.12 & 0.08 & 1.482 & 16.24 & 12.993 & 41.59 & 24.10 \\
\hline 0.0800 & 0.05000 & 0.15 & 0.09 & 1.495 & 15.61 & 12.485 & 38.27 & 18.78 \\
\hline 0.0800 & 0.05000 & 0.18 & 0.11 & 1.508 & 13.94 & 11.153 & 33.92 & 13.08 \\
\hline 0.08 & 0.05000 & 0.21 & 0.13 & 1.520 & 13.07 & 10.458 & 31.12 & 10.10 \\
\hline 0.08 & 0.05000 & 0.25 & 0.16 & 1.535 & 12.11 & 9.684 & 28.09 & 7.43 \\
\hline 0.08 & 0.05000 & 0.29 & 0.18 & 1.548 & 11.30 & 9.038 & 25.64 & 5.65 \\
\hline 0.08 & 0.05000 & 0.32 & 0.20 & 1.556 & 10.76 & 8.606 & 24.09 & 4.68 \\
\hline 0.08 & 0.05000 & 0.36 & 0.23 & 1.567 & 10.15 & 8.118 & 22.31 & 3.72 \\
\hline
\end{tabular}


Table D.3 (continued)

\begin{tabular}{|c|c|c|c|c|c|c|c|c|}
\hline \multirow[b]{2}{*}{$\mathrm{g} \mathrm{Pu} / \mathrm{cm}^{3}$} & \multirow[b]{2}{*}{$\mathrm{g} \mathrm{Pu} / \mathrm{g} \mathrm{SiO}_{2}$} & \multirow[b]{2}{*}{$\mathrm{g} \mathrm{H}_{2} \mathrm{O} / \mathrm{cm}^{3}$} & \multirow[b]{2}{*}{$\begin{array}{l}\mathrm{g} \mathrm{H}_{2} \mathrm{O} \\
/ \mathrm{g} \mathrm{SiO}_{2} \\
\end{array}$} & \multirow[b]{2}{*}{$k_{i n f}$} & \multicolumn{2}{|c|}{ Critical slab } & \multicolumn{2}{|c|}{ Critical sphere } \\
\hline & & & & & $\begin{array}{l}\text { Thickness } \\
(\mathrm{cm})\end{array}$ & $\begin{array}{c}\text { Areal } \\
\text { density } \\
\left(\mathrm{kg} \mathrm{Pu} / \mathrm{m}^{2}\right)\end{array}$ & $\begin{array}{l}\text { Radius } \\
(\mathrm{cm})\end{array}$ & $\mathrm{kg} \mathrm{Pu}$ \\
\hline 0.08 & 0.05000 & 0.40 & 0.25 & 1.575 & 9.94 & 7.950 & 21.24 & 3.21 \\
\hline 0.25 & 0.15625 & 0.00 & 0.00 & 1.848 & 11.56 & 28.908 & 56.71 & 190.97 \\
\hline 0.25 & 0.15625 & 0.03 & 0.02 & 1.744 & 10.79 & 26.978 & 45.71 & 100.04 \\
\hline 0.25 & 0.15625 & 0.06 & 0.04 & 1.669 & 10.83 & 27.075 & 40.60 & 70.10 \\
\hline 0.25 & 0.15625 & 0.09 & 0.06 & 1.609 & 10.74 & 26.858 & 36.91 & 52.66 \\
\hline 0.25 & 0.15625 & 0.12 & 0.08 & 1.587 & 10.56 & 26.408 & 33.99 & 41.11 \\
\hline 0.25 & 0.15625 & 0.15 & 0.09 & 1.566 & 10.90 & 27.245 & 31.84 & 33.82 \\
\hline 0.25 & 0.15625 & 0.18 & 0.11 & 1.551 & 10.03 & 25.085 & 29.41 & 26.63 \\
\hline 0.25 & 0.15625 & 0.21 & 0.13 & 1.542 & 9.73 & 24.320 & 27.56 & 21.92 \\
\hline 0.25 & 0.15625 & 0.25 & 0.16 & 1.535 & 9.31 & 23.278 & 25.42 & 17.19 \\
\hline 0.25 & 0.15625 & 0.29 & 0.18 & 1.531 & 8.90 & 22.245 & 23.57 & 13.71 \\
\hline 0.25 & 0.15625 & 0.32 & 0.20 & 1.531 & 8.60 & 21.498 & 22.35 & 11.69 \\
\hline 0.25 & 0.15625 & 0.36 & 0.23 & 1.531 & 8.22 & 20.543 & 20.89 & 9.55 \\
\hline 0.25 & 0.15625 & 0.38 & 0.24 & 1.532 & 8.33 & 20.835 & 20.46 & 8.96 \\
\hline 1 & 0.62500 & 0.00 & 0.00 & 2.279 & 3.03 & 30.290 & 28.93 & 101.37 \\
\hline 1 & 0.62500 & 0.03 & 0.02 & 2.125 & 3.25 & 32.460 & 26.42 & 77.26 \\
\hline 1 & 0.62500 & 0.06 & 0.04 & 2.043 & 3.64 & 36.360 & 24.65 & 62.72 \\
\hline 1 & 0.62500 & 0.09 & 0.06 & 1.983 & 3.96 & 39.560 & 23.15 & 51.94 \\
\hline 1 & 0.62500 & 0.12 & 0.08 & 1.934 & 4.21 & 42.110 & 21.86 & 43.77 \\
\hline 1 & 0.62500 & 0.15 & 0.09 & 1.892 & 4.67 & 46.730 & 21.15 & 39.62 \\
\hline 1 & 0.62500 & 0.18 & 0.11 & 1.855 & 4.55 & 45.490 & 19.79 & 32.45 \\
\hline 1 & 0.62500 & 0.21 & 0.13 & 1.824 & 4.65 & 46.510 & 18.92 & 28.39 \\
\hline 1 & 0.62500 & 0.25 & 0.16 & 1.788 & 4.74 & 47.350 & 17.91 & 24.06 \\
\hline 1 & 0.62500 & 0.29 & 0.18 & 1.757 & 4.77 & 47.730 & 17.01 & 20.63 \\
\hline 1 & 0.62500 & 0.32 & 0.20 & 1.737 & 4.78 & 47.790 & 16.41 & 18.50 \\
\hline 1 & 0.62500 & 0.35 & 0.22 & 1.719 & 5.00 & 50.000 & 16.23 & 17.92 \\
\hline
\end{tabular}


Table D.4 Plutonium-241 systems

\begin{tabular}{|c|c|c|c|c|c|c|c|c|}
\hline \multirow[b]{2}{*}{$\mathrm{g}^{241} \mathrm{Pu} / \mathrm{cm}^{3}$} & \multirow[b]{2}{*}{$\begin{array}{c}\mathrm{g}{ }^{241} \mathrm{Pu} / \mathrm{g} \\
\mathrm{SiO}_{2}\end{array}$} & \multirow[b]{2}{*}{$\mathrm{g} \mathrm{H}_{2} \mathrm{O} / \mathrm{cm}^{3}$} & \multirow[b]{2}{*}{$\begin{array}{l}\mathrm{g} \mathrm{H}_{2} \mathrm{O} \\
/ \mathrm{g} \mathrm{SiO}_{2}\end{array}$} & \multirow[b]{2}{*}{$k_{i n f}$} & \multicolumn{2}{|c|}{ Critical slab } & \multicolumn{2}{|c|}{ Critical sphere } \\
\hline & & & & & $\begin{array}{l}\text { Thickness } \\
\text { (cm) }\end{array}$ & $\begin{array}{l}\text { Areal density } \\
\left(\mathrm{kg}^{241} \mathrm{Pu} / \mathrm{m}^{2}\right)\end{array}$ & $\begin{array}{l}\text { Radius } \\
(\mathrm{cm})\end{array}$ & $\mathrm{kg}{ }^{241} \mathrm{Pu}$ \\
\hline 0.00049 & 0.00031 & 0.00 & 0.00 & 0.950 & & & & \\
\hline 0.00051 & 0.00032 & 0.00 & 0.00 & & 973.19 & 4.963 & & \\
\hline 0.00052 & 0.00033 & 0.00 & 0.00 & & 774.62 & 4.028 & & \\
\hline 0.00054 & 0.00034 & 0.00 & 0.00 & & 578.32 & 3.123 & & \\
\hline 0.00056 & 0.00035 & 0.00 & 0.00 & & 477.29 & 2.673 & & \\
\hline 0.00058 & 0.00036 & 0.00 & 0.00 & & 413.58 & 2.399 & & \\
\hline 0.00060 & 0.00038 & 0.00 & 0.00 & & 368.84 & 2.213 & & \\
\hline 0.00062 & 0.00039 & 0.00 & 0.00 & & 335.17 & 2.078 & & \\
\hline 0.00063 & 0.00039 & 0.00 & 0.00 & & 321.25 & 2.024 & & \\
\hline 0.00064 & 0.00040 & 0.00 & 0.00 & & 308.79 & 1.976 & & \\
\hline 0.00065 & 0.00041 & 0.00 & 0.00 & & 297.67 & 1.935 & & \\
\hline 0.00066 & 0.00041 & 0.00 & 0.00 & & 287.38 & 1.897 & & \\
\hline 0.0045 & 0.0028 & 0.32 & 0.20 & & & & 38.93 & 1.112 \\
\hline 0.0045 & 0.0028 & 0.36 & 0.23 & & & & 38.56 & 1.081 \\
\hline 0.0045 & 0.0028 & 0.40 & 0.25 & & & & 38.54 & 1.079 \\
\hline 0.0055 & 0.0034 & 0.32 & 0.20 & & & & 33.95 & 0.902 \\
\hline 0.0055 & 0.0034 & 0.36 & 0.23 & & & & 33.13 & 0.838 \\
\hline 0.0055 & 0.0034 & 0.40 & 0.25 & & & & 32.56 & 0.795 \\
\hline 0.0065 & 0.0041 & 0.32 & 0.20 & & & & 30.91 & 0.804 \\
\hline 0.0065 & 0.0041 & 0.36 & 0.23 & & & & 29.90 & 0.728 \\
\hline 0.0065 & 0.0041 & 0.40 & 0.25 & & & & 29.11 & 0.672 \\
\hline 0.0100 & 0.0063 & 0.32 & 0.20 & & & & 25.64 & 0.706 \\
\hline 0.0100 & 0.0063 & 0.36 & 0.23 & & & & 24.45 & 0.612 \\
\hline 0.0100 & 0.0063 & 0.40 & 0.25 & & & & 23.46 & 0.541 \\
\hline 0.0130 & 0.0081 & 0.40 & 0.25 & & & & 21.27 & 0.524 \\
\hline 0.0160 & 0.0100 & 0.32 & 0.20 & & & & 22.20 & 0.733 \\
\hline 0.0160 & 0.0100 & 0.36 & 0.23 & & & & 20.97 & 0.618 \\
\hline 0.0160 & 0.0100 & 0.40 & 0.25 & & & & 19.94 & 0.531 \\
\hline 0.0225 & 0.0141 & 0.32 & 0.20 & & & & 20.51 & 0.813 \\
\hline 0.0225 & 0.0141 & 0.36 & 0.23 & & & & 19.30 & 0.678 \\
\hline 0.0225 & 0.0141 & 0.40 & 0.25 & & & & 18.26 & 0.574 \\
\hline 0.0800 & 0.0500 & 0.32 & 0.20 & & & & 16.96 & 1.635 \\
\hline 0.0800 & 0.0500 & 0.36 & 0.23 & & & & 15.85 & 1.334 \\
\hline 0.0800 & 0.0500 & 0.40 & 0.25 & & & & 14.89 & 1.106 \\
\hline
\end{tabular}




\section{APPENDIX E}

\section{COMPARISONS OF OTHER ELEMENTS TO SILICON}




\section{APPENDIX E COMPARISONS OF OTHER ELEMENTS TO SILICON}

Table E.1 Substitution of element $\mathrm{X}$ into $\mathrm{SiO}_{2}$, forming $\mathrm{XO}_{2}$

\begin{tabular}{|c|c|c|}
\hline Atomic No. & Element & $k_{i n f}$ \\
\hline 1 & $\mathrm{H}$ & 0.640 \\
\hline 2 & $\mathrm{He}$ & 2.020 \\
\hline 3 & $\mathrm{Li}$ & 0.014 \\
\hline 4 & $\mathrm{Be}$ & 1.985 \\
\hline 5 & $\mathrm{~B}$ & 0.002 \\
\hline 6 & $\mathrm{C}$ & 1.975 \\
\hline 7 & $\mathrm{~N}$ & 0.132 \\
\hline 8 & $\mathrm{O}$ & 1.996 \\
\hline 9 & $\mathrm{~F}$ & 1.871 \\
\hline 10 & $\mathrm{Ne}$ & $\mathrm{N} / \mathrm{A}^{a}$ \\
\hline 11 & $\mathrm{Na}$ & 0.437 \\
\hline 12 & $\mathrm{Mg}$ & 1.408 \\
\hline 13 & $\mathrm{Al}$ & 0.768 \\
\hline 14 & $\mathrm{Si}$ & 0.949 \\
\hline 15 & $\mathrm{P}$ & 0.804 \\
\hline 16 & $\mathrm{~S}$ & 0.366 \\
\hline 17 & $\mathrm{Cl}$ & 0.037 \\
\hline 18 & $\mathrm{Ar}$ & N/A \\
\hline 19 & $\mathrm{~K}$ & 0.017 \\
\hline 20 & $\mathrm{Ca}$ & 0.440 \\
\hline 21 & $\mathrm{Sc}$ & N/A \\
\hline 22 & $\mathrm{Ti}$ & 0.088 \\
\hline 23 & $\mathrm{~V}$ & 0.076 \\
\hline 24 & $\mathrm{Cr}$ & 0.102 \\
\hline 25 & $\mathrm{Mn}$ & 0.028 \\
\hline 26 & $\mathrm{Fe}$ & 0.121 \\
\hline
\end{tabular}


Table E.1 (continued)

\begin{tabular}{|c|c|c|}
\hline Atomic No. & Element & $k_{i n f}$ \\
\hline 27 & Co & 0.019 \\
\hline 28 & $\mathrm{Ni}$ & 0.073 \\
\hline 29 & $\mathrm{Cu}$ & 0.058 \\
\hline 30 & $\mathrm{Zn}$ & 0.177 \\
\hline 31 & $\mathrm{Ga}$ & 0.010 \\
\hline 32 & $\mathrm{Ge}$ & 0.035 \\
\hline 33 & As & 0.004 \\
\hline 34 & $\mathrm{Se}$ & 0.019 \\
\hline 35 & $\mathrm{Br}$ & 0.003 \\
\hline 36 & $\mathrm{Kr}$ & 0.017 \\
\hline 37 & $\mathrm{Rb}$ & 0.148 \\
\hline 38 & $\mathrm{Sr}$ & 0.077 \\
\hline 39 & $\mathrm{Y}$ & 0.179 \\
\hline 40 & $\mathrm{Zr}$ & 0.633 \\
\hline 41 & $\mathrm{Nb}$ & 0.018 \\
\hline 42 & Mo & 0.009 \\
\hline 43 & $\mathrm{Tc}$ & 0.002 \\
\hline 44 & $\mathrm{Ru}$ & 0.003 \\
\hline 45 & $\mathrm{Rh}$ & 0.002 \\
\hline 46 & $\mathrm{Pd}$ & 0.003 \\
\hline 47 & $\mathrm{Ag}$ & 0.002 \\
\hline 48 & $\mathrm{Cd}$ & 0.004 \\
\hline 49 & In & 0.003 \\
\hline 50 & $\mathrm{Sn}$ & 0.039 \\
\hline 51 & $\mathrm{Sb}$ & 0.003 \\
\hline 52 & $\mathrm{Te}$ & 0.015 \\
\hline
\end{tabular}


Table E.1 (continued)

\begin{tabular}{|c|c|c|}
\hline Atomic No. & Element & $k_{i n f}$ \\
\hline 53 & I & 0.002 \\
\hline 54 & $\mathrm{Xe}$ & 0.007 \\
\hline 55 & $\mathrm{Cs}$ & 0.003 \\
\hline 56 & $\mathrm{Ba}$ & 0.044 \\
\hline 57 & $\mathrm{La}$ & 0.046 \\
\hline 58 & $\mathrm{Ce}$ & 0.336 \\
\hline 59 & $\operatorname{Pr}$ & 0.012 \\
\hline 60 & $\mathrm{Nd}$ & 0.009 \\
\hline 61 & $\mathrm{Pm}$ & 0.002 \\
\hline 62 & $\mathrm{Sm}$ & 0.002 \\
\hline 63 & $\mathrm{Eu}$ & 0.001 \\
\hline 64 & $\mathrm{Gd}$ & 0.002 \\
\hline 65 & $\mathrm{~Tb}$ & 0.001 \\
\hline 66 & Dy & 0.002 \\
\hline 67 & Ho & 0.001 \\
\hline 68 & $\mathrm{Er}$ & 0.002 \\
\hline 69 & $\mathrm{Tm}$ & N/A \\
\hline 70 & $\mathrm{Yb}$ & N/A \\
\hline 71 & $\mathrm{Lu}$ & 0.001 \\
\hline 72 & $\mathrm{Hf}$ & 0.002 \\
\hline 73 & $\mathrm{Ta}$ & 0.002 \\
\hline 74 & $\mathrm{~W}$ & 0.002 \\
\hline 75 & $\mathrm{Re}$ & 0.002 \\
\hline 76 & Os & N/A \\
\hline 77 & $\mathrm{Ir}$ & N/A \\
\hline 78 & $\mathrm{Pt}$ & N/A \\
\hline
\end{tabular}


Table E.1 (continued)

\begin{tabular}{ccc}
\hline Atomic No. & Element & $k_{\text {inf }}$ \\
\hline 79 & $\mathrm{Au}$ & 0.003 \\
80 & $\mathrm{Hg}$ & $\mathrm{N} / \mathrm{A}$ \\
81 & $\mathrm{Tl}$ & $\mathrm{N} / \mathrm{A}$ \\
82 & $\mathrm{~Pb}$ & 0.899 \\
83 & $\mathrm{Bi}$ & 1.430 \\
84 & $\mathrm{Po}$ & N/A \\
85 & $\mathrm{At}$ & N/A \\
86 & $\mathrm{Rn}$ & N/A \\
87 & $\mathrm{Fr}$ & N/A \\
88 & $\mathrm{Ra}$ & N/A \\
89 & $\mathrm{Ac}$ & N/A \\
90 & $\mathrm{Th}$ & 0.065 \\
91 & $\mathrm{~Pa}$ & 0.792 \\
92 & $\mathrm{U}(\mathrm{natural})$ & 0.391 \\
\hline
\end{tabular}

${ }^{a} \mathrm{~N} / \mathrm{A}=$ Cross sections not available in SCALE libraries. 
Table E.2 Substitution of other substances for $\mathrm{SiO}_{2}$

\begin{tabular}{lc}
\hline \multicolumn{1}{c}{ Substance } & $k_{\text {inf }}$ \\
\hline Heavy Water $\left(\mathrm{D}_{2} \mathrm{O}\right)$ & 2.032 \\
$\mathrm{Be}$ (elemental) & 1.572 \\
$\mathrm{C}$ (graphite) & 1.856 \\
$\mathrm{Mg}$ (elemental) & 0.970 \\
$\mathrm{MgF}_{2}$ & 1.297 \\
$\mathrm{CaF}_{2}$ & 0.528 \\
Nominal soil $^{a}$ & 0.672 \\
Limestone $^{b}$ & 0.648 \\
\hline
\end{tabular}

${ }^{a}$ Nominal soil composition in weight percent (wt \%):

$$
\begin{aligned}
& \mathrm{Ca}=1.37 \% \\
& \mathrm{C}=4.29 \% \\
& \mathrm{O}=49.00 \% \\
& \mathrm{Si}=33.00 \% \\
& \mathrm{Al}=7.1 \% \\
& \mathrm{~K}=1.36 \% \\
& \mathrm{Na}=0.68 \% \\
& \mathrm{Mg}=0.60 \% \\
& \mathrm{Fe}=2.60 \%
\end{aligned}
$$

${ }^{b}$ Limestone composition in weight percent (wt \%):

$$
\begin{aligned}
& \mathrm{Ca}=34.04 \% \\
& \mathrm{C}=9.98 \% \\
& \mathrm{O}=47.91 \% \\
& \mathrm{Si}=5.51 \% \\
& \mathrm{Al}=1.45 \% \\
& \mathrm{~K}=0.70 \% \\
& \mathrm{Na}=0.41 \%
\end{aligned}
$$




\section{APPENDIX F}

\section{SPECIFIC ACTIVITY VALUES FOR SELECTED ISOTOPES}




\section{APPENDIX F \\ SPECIFIC ACTIVITY VALUES FOR SELECTED ISOTOPES}

Table F.1 Specific activity values for selected isotopes

\begin{tabular}{ccc}
\hline Isotope & Specific activity $(\mathrm{Ci} / \mathrm{g})$ & Specific activity $(\mathrm{MBq} / \mathrm{g})$ \\
\hline Uranium-233 & $9.650 \mathrm{E}-3$ & $3.571 \mathrm{E}+2$ \\
Uranium-235 & $2.164 \mathrm{E}-6$ & $8.007 \mathrm{E}-2$ \\
Uranium-238 & $3.366 \mathrm{E}-7$ & $1.245 \mathrm{E}-2$ \\
Plutonium-239 & $6.212 \mathrm{E}-2$ & $2.298 \mathrm{E}+3$ \\
Plutonium-240 & $2.273 \mathrm{E}-1$ & $8.410 \mathrm{E}+3$ \\
Plutonium-241 & $1.035 \mathrm{E}+2$ & $3.830 \mathrm{E}+6$ \\
\hline
\end{tabular}




\section{INTERNAL DISTRIBUTION}

1. S. M. Bowman, 6011, MS-6370

2. B. L. Broadhead, 6011, MS-6370

3. W. C. Carter, 6011, MS-6370

4. M. E. Dunn, 6011, MS-6370

5. M. D. DeHart, 6011, MS-6370

6. K. R. Elam, 6011, MS-6370

7. M. B. Emmett, 6011, MS-6370

8. C. W. Forsberg, 4500 N, MS-6180

9. N. M. Greene, 6011, MS-6370

10. G. R. Handley, 9110, MS-8238

11. D. F. Hollenbach, 6011, MS-6370

12. C. M. Hopper, 6011, MS-6370

13. B. L. Kirk, 6025, MS-6362

14. M. A. Kuliasha, 6025, MS-6435

15. L. C. Leal, 6011, MS-6370
16. C. V. Parks, 6011, MS-6370

17. L. M. Petrie, 6011, MS-6370

18. R. T. Primm III, 6025, MS-6363

19. B. T. Rearden, 6011, MS-6370

20. R. C. Robinson, 9110, MS-8238

21. R. G. Taylor, 9119, MS-8235

22. T. E. Valentine, 6010, MS-6354

23. R. M. Westfall, 6011, MS-6370

24. Central Research Library,

Document Reference Section 4500N, MS-6191

25. ORNL Laboratory Records - RC 4500N, MS-6254

\section{EXTERNAL DISTRIBUTION}

26. F. M. Alcorn, BWX Technologies, Inc., Naval Nuclear Fuel, 212 Windsor Rd., Lynchburg, VA 24502

27. S. Almodovar, Fluor Daniel Hanford, P.O. Box 1000, Mail Stop A3-02, Richland, WA 99352-1000

28. S. Altschuler, U.S. Department of Energy, Richland Operations, 825 Jadwin, R3-79, Richland, WA 99352

29. R. E. Anderson, Los Alamos National Laboratory, P.O. Box 1663, NIS-6, MS J562, Los Alamos, NM 87545

30. W. L. Andrews, Defense Nuclear Facilities Safety Board, 625 Indiana Ave., Washington, DC 20004

31. C. Apperson, Westinghouse Savannah River Company, Savannah River Site, Bldg. 773-11A, Aiken, SC 29808-0001

32. M. G. Bailey, U.S. Nuclear Regulatory Commission, NMSS, MS T8 A23, Washington, DC 20555-0001

33. G. H. Bidinger, Nuclear Criticality Safety, 17016 Cashell Road, Rockville, MD 20853 
34. R. N. Blomquist, Argonne National Laboratory, RA/208, 9700 S. Case Ave., Argonne, IL 60439-4842

35. C. Boman, BWX Technologies, Inc., Naval Nuclear Fuel, P.O. Box 785, Lynchburg, VA 24505

36. M. C. Brady Raap, Duke Engineering Services, 10503 W. Williams Road, Benton City, WA 99320

37. J. B. Briggs, INEEL, P.O. Box 1625, MS-3855, Idaho Falls, ID 83402

38. T. Burns, Defense Nuclear Facilities Safety Board, 625 Indiana Ave., Washington, DC 20004

39. R. D. Busch, University of New Mexico, Chemical and Nuclear Engineering Department, FEC 209, Albuquerque, NM 87131-1341

40. D. E. Cabrilla, U.S. DOE EM-66, Nuclear Material Stabilization, 19901 Germantown Road, Germantown, MD 20874-1290

41. D. E. Carlson, U.S. Nuclear Regulatory Commission, NMSS/SFPO/TRD, MS O13 D13, Washington, DC 20555-0001

42. K. J. Carroll, Lockheed Martin Energy Systems, Y-12 Plant, P.O. Box 2009, Oak Ridge, TN 37831-8238

43. P. Cousinou, Institute of Protection and Nuclear Safety, B. P. 6 - 92265 Fontenay-AuxRoses, Cedex, France

44. D. R. Damon, U.S. Nuclear Regulatory Commission, NMSS, MS T8 A33, Washington, DC 20555-0001

45. J. R. Davis, U.S. Nuclear Regulatory Commission, NMSS/FCSS, MS T8-A33, Washington, DC 20555-0001

46. J. W. Davis, Framatome Cogema Fuels, CRWMS M\&O, 1261 Town Center Dr., Las Vegas, NV 89134

47. R. L. Dintaman, U.S. Department of Energy, DP-13, 19901 Germantown Rd., Germantown, MD 20874-1290

48. H. L. Dodds, University of Tennessee, Nuclear Engineering Dept., 214 Pasqua Engineering Bldg., Knox ville, TN 37922

49. T. W. Doering, Framatome Cogema Fuels, 1261 Town Center Drive, Las Vegas, NV 89124

50. F. Eltawila, U.S. Nuclear Regulatory Commission, RES/DSARE, MS T10 E32, Washington, DC 20555-0001

51. J. D. Evans, U.S. Department of Energy, S-3.1/VISTA, 1000 Independence Ave., S.W., Washington, DC 22085

52. H. D. Felsher, U.S. Nuclear Regulatory Commission, NMSS/FCSS/FLIB, MS T8 A33, Washington, DC 20555-0001

53. P. Felsher, Rocky Flats Environment Technology Site, Bldg. T886B, P.O. Box 464, Golden, CO 80402-0464

54. J. R. Felty, Science Applications Int'1 Corp., 2418 N. Dickerson St., Arlington, VA 22207

55. I. E. Fergus, U.S. Department of Energy, EH-22, 20300 Century Blvd., Germantown, MD 20874 
56. P. Finck, Argonne National Laboratory, 9700 South Cass Avenue, RA/208, Argonne, IL 60439-4842

57. E. K. Fujita, Argonne National Laboratory, 9700 South Cass Avenue, RA/208, Argonne, IL 60439-4842

58. A. S. Garcia, U.S. Department of Energy, Idaho Operations Office, 850 Energy Dr., MS 1154, Idaho Falls, ID 83401-1563

59. E. Greenspan, University of California, 4101 Etchevenny Hall, Berkeley, CA 94720

60. J. Gulliford, AEA Technology Engineering Services, Inc., 241 Curry Hollow Road, Pittsburgh, PA 15236-4696

61. D. K. Hays, Los Alamos National Laboratory, P. O. Box 1663, Los Alamos, NM 87545

62. D. Heinrichs, Lawrence Livermore National Laboratory, P.O. Box 808, MS L-128, Livermore, CA 94551

63. A. B. Hoffman, Lockheed Martin Idaho Tech. Co., P.O. Box 1625, MS 3458, Idaho Falls, ID 83415-3458

64. S. T. Huang, Lawrence Livermore National Laboratory, MS L-128, P.O. Box 808, Livermore, CA 94551

65. J. C. Ingram, Bechtel Jacobs Company LLC, P. O. Box 4699, Bldg. K-1320, MS-7592, Oak Ridge, TN 37831-7592

66. E. F. Kendall, U.S. Department of Energy, Oak Ridge Operations Office, YSO, P.O. Box 2001, Oak Ridge, TN 37831

67. K. D. Kimball, NISYS Corporation, 6055 Atlantic Blvd., Suite G-2, Norcross, GA 30071

68. R. P. Koopman, Lawrence Livermore National Lab., P.O. Box 808, L-467, Livermore, CA 94551

69. M. A. Lee, U.S. Department of Energy, Livermore Operations, 7000 East St., P.O. Box 808, L-293, Livermore, CA 94551-0808

70. R. Libby, Pacific Northwest National Laboratory, P.O. Box 999, M/S K7-74, Richland, WA 99352

71. J. J. Lichtenwalter, Bechtel Jacobs Company LLC, c/o BWXT Y-12, P.O. Box 2009, Bldg. 9110, MS-8238, Oak Ridge, TN 37831-8238

72. R. C. Little, Los Alamos National Laboratory, MS F663, P.O. Box 1663, Los Alamos, NM 87545

73. C. D. Manning, Siemens Power Corporation, 2101 Horn Rapids Road, P.O. Box 130, Richland, WA 99352-0130

74. R. McBroom, U.S. Department of Energy, Oak Ridge Operations Office, YSO, P.O. Box 2001, Oak Ridge, TN 37831

75. J. McKamy, U.S. Department of Energy, EH-34, 19901 Germantown Road, Germantown, MD 20874-1290

76. R. D. McKnight, Argonne National Laboratory, 9700 S. Cass Ave., Argonne, IL 60439-4842

77. T. P. McLaughlin, Los Alamos National Laboratory, P. O. Box 1663, Los Alamos, NM 87545

78. D. E. I. Mennerdal, E M Systems, Starvãgen 12, Täby, SWEDEN S-18357 
79. R. D. Montgomery, Nuclear Fuel Services, Inc., 1205 Banner Hill Rd., Erwin, TN 37650

80. D. C. Morey, U.S. Nuclear Regulatory Commission, NMSS/FCSS/FCOB, MS T8 A33, Washington, DC 20555-0001

81. J. A. Morman, Argonne National Laboratory, 9700 S. Cass Ave., Bldg. 208, C237B, Argonne, IL 60439-4842

82. R. D. Mosteller, Los Alamos National Laboratory, MS J562, Los Alamos, NM 87545

83. K. A. Niemer, Duke Engineering \& Services, 400 S. Tryon St., WC26B, P.O. Box 1004, Charlotte, NC 28201-1004

84-85. Office of Scientific and Technical Information, U.S. Department of Energy, P.O. Box 62, Oak Ridge, TN 37831

86. H. Okuno, Japan Atomic Energy Research Institute, 2-4 Shirakara-shirane, Tokai-mura, Ibaraki-ken, JAPAN 319-1195

87. S. A. Parra, Lawrence Livermore National Laboratory, P.O. Box 808, MS L-128, Livermore, CA 94551

88. L. E. Paulson, Manager, Nuclear Safety, GE Nuclear Energy, P.O. Box 780, Castle Hayne Road, Wilmington, NC 28405

89. S. Payne, U.S. DOE/AL/SASD, P.O. Box 5400, Albuquerque, NM 87185-5400

90. V. A. Perin, U.S. Nuclear Regulatory Commission, NMSS/FCSS/SPB, MS T8 A33, Washington, DC 20555-0001

91. J. Person, Lawrence Livermore National Laboratory, P.O. Box 808, MS L-128, Livermore, CA 94551

92. R. E. Pevey, University of Tennessee, Nuclear Engineering Dept., 214 Pasqua Engineering Bldg., Knoxville, TN 37922

93. J. Philbin, Sandia National Laboratory, P.O. Box 5800, Albuquerque, NM 87185-1143

94. A. W. Prichard, Pacific Northwest National Laboratory, P.O. Box 999, MSIN: K8-34, Richland, WA 99352

95. M. Rahimi, U.S. Nuclear Regulatory Commission, NMSS/DWH/HLWB, MS T7 F3, Washington, DC 20555-0001

96. T. A. Reilly, Westinghouse Safety Management Solutions, 1993 South Centennial Dr., Aiken, SC 29803

97. J. D. Roarty, Defense Nuclear Facilities Safety Board, 625 Indiana Ave., N.W., Suite 700, Washington, DC 2004

98. C. Rogers, Duke Engineering Services, 10503 W. Williams Road, Benton City, WA 99320

99. C. T. Rombough, CTR Technical Services, Inc., 950 Sugarloaf Rd., Manitou Springs, CO 80829

100. B. Rothleder, U.S. Department of Energy, EH-31, 19901 Germantown Rd., Germantown, MD 20874-1290

101. M. K. Sheaffer, Lawrence Livermore National Laboratory, P.O. Box 808, L-634, Livermore, CA 94550

102. G. L. Stimmell, Manager, General Electric Co., Vallecitos Nuclear Center, P.O. Box 460, Vallecitos Road, Pleasanton, CA 94566 
103. J. T. Taylor, Principle Engineer - CSE, GE Nuclear Energy, P.O. Box 780, Castle Hayne Road, Wilmington, NC 28402

104. T. Taylor, Lockheed Martin Idaho Tech. Co., P.O. Box 1625, MS 3458, Idaho Falls, ID 83415-3458

105. D. A. Thomas, Framatome Cogema Fuels, 1261 Town Center Drive, Las Vegas, NV 89124

106. C. Tripp, U.S. Nuclear Regulatory Commission, MS T8-A33, Washington, DC 20555

107. H. Toffer, Fluor Daniel Northwest, Inc., P.O. Box 1050, MSIN B4-44, 1100 Jadwin Ave., Richland, WA 99352-1050

108. E. F. Trumble, Westinghouse Safety Management Solutions, P.O. Box 5388, 1993 South Centennial Dr., Aiken, SC 29803

109. J. J. Wagschal, Racah Institute of Physics, The Hebrew University of Jerusalem, 91904, Jerusalem, ISRAEL

110. M. Wangler, Office of Site Operations, EM-70/CLV-1059, U.S. Department of Energy, 19901 Germantown Road, Germantown, MD 20874-1290

111. L. Wetzel, BWX Technologies, Inc., Naval Nuclear Fuel, P.O. Box 785, Lynchburg, VA 24505

112. S. A. Whaley, U.S. Nuclear Regulatory Commission, NMSS/SFPO/TRD, MS O13 D13, Washington, DC 20555-0001

113. B. H. White IV, U.S. Nuclear Regulatory Commission, NMSS/SFPO/TRD, MS O13 D13, Washington, DC 20555-0001

114. D. W. Williams, Westinghouse Electric Corporation, 5801 Bluff Rd MS\#15, Columbia, SC 29209

115. Mark Williams, Louisiana State University, Baton Rouge, LA 70803-5820

116. R. E. Wilson, DOE Rocky Flats, 10808 Highway 93, Unit A, Golden, CO 80403

117. C. J. Withee, U.S. Nuclear Regulatory Commission, NMSS/SFPO/TRD, MS O13 D13, Washington, DC 20555-0001 
